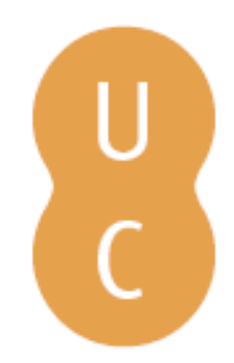

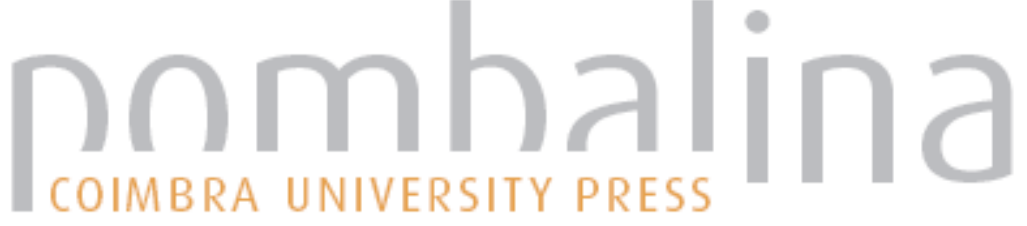

\section{Obras morais: o banquete dos sete sábios}
Autor(es):
Plutarco
Publicado por: Centro de Estudos Clássicos e Humanísticos
URL persistente:
URI:http://hdl.handle.net/10316.2/2406
DOI:
DOI:http://dx.doi.org/10.14195/978-989-721-066-2

Accessed : $\quad$ 26-Apr-2023 12:13:08

A navegação consulta e descarregamento dos títulos inseridos nas Bibliotecas Digitais UC Digitalis, UC Pombalina e UC Impactum, pressupõem a aceitação plena e sem reservas dos Termos e Condições de Uso destas Bibliotecas Digitais, disponíveis em https://digitalis.uc.pt/pt-pt/termos.

Conforme exposto nos referidos Termos e Condições de Uso, o descarregamento de títulos de acesso restrito requer uma licença válida de autorização devendo o utilizador aceder ao(s) documento(s) a partir de um endereço de IP da instituição detentora da supramencionada licença.

Ao utilizador é apenas permitido o descarregamento para uso pessoal, pelo que o emprego do(s) título(s) descarregado(s) para outro fim, designadamente comercial, carece de autorização do respetivo autor ou editor da obra.

Na medida em que todas as obras da UC Digitalis se encontram protegidas pelo Código do Direito de Autor e Direitos Conexos e demais legislação aplicável, toda a cópia, parcial ou total, deste documento, nos casos em que é legalmente admitida, deverá conter ou fazer-se acompanhar por este aviso.

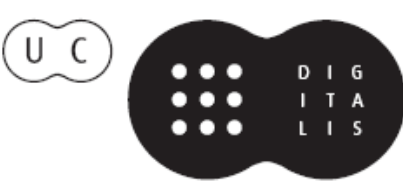




\section{Plutarco}

Obras Morais O Banquete dos Sete Sábios 
Série "Autores Gregos e Latinos -

TRADUÇÃO, INTRODUÇÁO E COMENTÁRIO”

ISSN: 2183-220X

Apresentação: Esta série procura apresentar em língua portuguesa obras de autores gregos, latinos e neolatinos, em tradução feita diretamente a partir da língua original. Além da tradução, todos os volumes são também caraterizados por conterem estudos introdutórios, bibliografia crítica e notas. Reforça-se, assim, a originalidade científica e o alcance da série, cumprindo o duplo objetivo de tornar acessíveis textos clássicos, medievais e renascentistas a leitores que náo dominam as línguas antigas em que foram escritos. Também do ponto de vista da reflexão académica, a coleçáo se reveste no panorama lusófono de particular importância, pois proporciona contributos originais numa área de investigaçáo científica fundamental no universo geral do conhecimento e divulgaçáo do património literário da Humanidade. 
(Página deixada propositadamente em branco) 
Volume integrado no projecto

Plutarco e os fundamentos da identidade europeia

e financiado pela Fundação para a Ciência e a Tecnologia.

Investigador responsável pelo projecto: Delfim Ferreira Leão. 


\section{Plutarco}

\section{Obras Morais \\ O Banquete dos Sete Sábios}

TraduÇÃo do GREgo, INTRODUÇÃo E NOTAS DE

Delfim F. Leão

Universidade de Coimbra

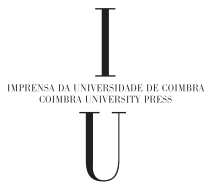


Autor: Plutarco

Título: Obras Morais. O Banquete dos Sete Sábios Traduçấo do grego, introdução e notas: Delfim F. LeÃo Editor: Centro de Estudos Clássicos e Humanísticos e Imprensa da Universidade de Coimbra EDIÇÃo: 1a / 2008

Concepçấo Gráfica: Rodolfo Lopes

ObRa REALIZADA No ÂMBITO DAS ACTIVIDADES DA UI\&D Centro de Estudos Clássicos e Humanísticos

$$
\begin{gathered}
\text { Universidade de Coimbra } \\
\text { Faculdade de Letras } \\
\text { Tel.: } 239859981 \text { | Fax: } 239836733 \\
\text { 3000-447 Coimbra }
\end{gathered}
$$

ISBN: 978-989-8281-05-0

ISBN Digital: 978-989-721-066-2

DOI: http://dx.doi.org/10.14195/978-989-721-066-2

Depósito Legal: 282468/08

Obra Publicada com o Apoio de:
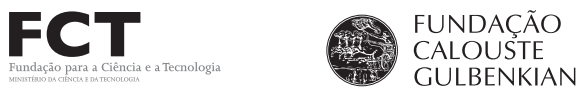

POCI $/ 2010$ 


\section{ÍNDICE}

INTRODUÇÃO

I. Estrutura da Obra, AUtORia E DATAÇÃo 7

2. A literatura de Sentenças 13

3. A literatura de banquete 19

4. Rituais de COMENSAlidade 23

5. O Banquete dos Sete Sabios de Plutarco 29

6. UMA SABEDoria 'Alternativa' no BANQUETE DOS SETE SABIOS 34

$\begin{array}{ll}\text { BiBLIOGRAFIA } & 41\end{array}$

O BANQUeTe dos Sete SABIos

$\begin{array}{ll}\text { ÍNDICE DE NoMes } & 125\end{array}$

$\begin{array}{lr}\text { Anexo } & 129\end{array}$ 


\section{INTRODUÇÃO}

\section{ESTRUTURA DA ObRA, AUTORIA E DATAÇáo}

O Banquete dos Sete Sábios (Septem Sapientium Conuiuium) constitui um pequeno tratado (Moralia, 146b-164d) em que Díocles, um velho adivinho, se propóe contar o banquete que decorrera, algum tempo antes, em casa do tirano Periandro, cuja corte o anciáo costumava frequentar. $\mathrm{O}$ relato é dirigido a Nicarco e a outros prováveis circunstantes náo identificados pelo nome, cuja função se esgota precisamente no papel de ouvintes. A narração assume, portanto, um carácter autodiegético, uma vez que Díocles participou também no banquete, ao lado dos Sete Sábios e demais convidados, facto que serviria de garantia suplementar para a veracidade dos factos evocados (146b-c). Em todo o caso, a voz do narrador acaba por ser muito discreta, uma vez que a obra segue o modelo dos diálogos socráticos, abrindo, portanto, espaço à intervenção de múltiplas personagens, em discurso directo. Além da forma dialógica adoptada, o influxo platónico é visível noutros aspectos da estrutura da obra: na presença de um prólogo, na forma como os vários argumentos se sucedem e vão sendo expostos, bem como no facto de a utilização do mito acentuar o ponto culminante da acção. ${ }^{1}$ Tem

${ }^{1}$ Neste caso, o mito em causa diz respeito ao salvamento de Aríon por golfinhos, complementado depois pelo relato das circunstâncias da morte de Hesíodo e de Énalo. É curioso notar que cabe a Anacársis expor sob a forma de conceito o significado destas aventuras, ao enunciar o princípio de que a alma é um instrumento de que a divindade se serve para governar o mundo (163d-f). 
sido identificada, igualmente, a presença de elementos de matriz cínica, em especial nas intervenções críticas de Tales e de Esopo, ou até na presença de Anacársis, um sábio de ressonâncias exóticas e impolutas. A estes aspectos há ainda que ajuntar o contributo determinante da literatura sapiencial e de sentenças.

Ora se, por um lado, a concomitância destes elementos acentua a confluência no Banquete dos Sete Sábios de uma tradição já muito longa, permitindo, igualmente, imprimir maior dinamismo e variedade à narrativa, será também de reconhecer que acaba por afectar um tanto a harmonia interna do opúsculo e, sobretudo, a possibilidade de se aprofundar a discussão de um ideário distintivo. Este aspecto, de certa forma inegável, levou no passado alguns estudiosos a defenderem a opinião de que esta obra seria indigna do polígrafo de Queroneia. No entanto, essa posição radical tem vindo entretanto a ser definitivamente posta de lado, com argumentos de peso. Antes de mais, porque se reconhece no Septem Sapientium Conuinium uma estrutura claramente orgânica, que, em termos esquemáticos, se pode resumir desta forma: há uma pequena introdução (146b-c) que serve para Díocles apresentar os créditos da narração; ${ }^{2}$ segue-se um prólogo, durante o qual se

Com esta intervenção, o sábio cita afasta-se da tradicional conotação cínica da sua caracterização, para se aproximar antes do providencialismo platónico, que Plutarco também partilharia. Para uma abordagem dos principais argumentos respeitantes a esta questão, vide Lo Cascio (1997) 11-21.

${ }^{2}$ A introdução e a parte final do epílogo constituem os momentos onde há uma intervenção discursiva mais directa do narrador autodiegético, sem contar obviamente com os comentários que 
facultam as usuais informaçôes sobre as circunstâncias que motivaram o encontro e sobre a chegada ao local onde irá decorrer o banquete (146c-149f); faz-se depois uma descrição do espaço do banquete (149f-150d), durante a qual se comenta também ironicamente a desistência intempestiva de um dos convivas (Alexidemo de Mileto, filho ilegítimo do tirano Trasibulo) por causa da distribuição dos lugares; em seguida, há um interlúdio (150d-155d) decorrente da análise da missiva apresentada por Nilóxeno, emissário do faraó Âmasis, a qual motivará não apenas as desejadas respostas dos Sábios aos enigmas colocados, como ainda outras consideraçóes sobre o governo democrático e sobre a melhor forma de administração doméstica; entra-se por fim na parte central do banquete propriamente dito (155d-164d), que servirá de cenário a discussóes variadas, sobre o amor e o vinho, sobre a medida ideal que se deve observar na posse dos bens materiais, sobre as vantagens e inconvenientes da alimentação; a entrada intempestiva de Gorgo, irmão do tirano Periandro, ${ }^{3}$ dá o mote para a narraçáo das aventuras de Aríon bem como de outras histórias com a mesma incidência temática, que acentuam o ponto culminante do banquete; depois de mais algumas consideraçóes finais (como o relato da forma como o pequeno Cípselo escapou aos executores

Díocles faz no espaço do banquete em si, visto que é também um dos comensais, ou na forma como é interpelado. Cf. 149d, e; 150b; 151f; 155 c; 162c.

${ }^{3} \mathrm{O}$ ingresso de Gorgo encontra, em termos genéricos, paralelo na forma como Alcibíades faz a sua entrada no banquete oferecido por Ágaton, constituindo, portanto, mais uma das marcas do influxo platónico na obra de Plutarco. 
ou a explicação de certas máximas sapienciais), chega-se ao epílogo (164d), com Sólon a propor o encerramento do encontro, não sem antes serem feitas libaçóes às Musas, a Poséidon e a Anfitrite. ${ }^{4}$

A estrutura agora descrita mostra que existe, de facto, uma organização coerente da obra. Por conseguinte, se as questóes são tratadas com menor profundidade e se parece haver algum acaso na maneira como os interlocutores mudam de assunto, tais aspectos não devem ser lidos como sinal de que o trabalho foi escrito por outra pessoa que não Plutarco, mas antes como características distintivas deste género literário, cujo objectivo consiste precisamente em acentuar a espontaneidade e vivacidade de uma conversa à mesa. Por outro lado, as marcas estilísticas e a própria relação temática e textual com a restante produção do biógrafo e moralista reforçam, também, o carácter genuíno do tratado ou, se preferirmos, a efectiva "autotextualidade". ${ }^{5}$ Ainda assim, não é possível recolher no Banquete dos Sete Sábios indícios seguros sobre a evolução do pensamento de Plutarco, a ponto de permitirem estabelecer com segurança uma datação inequívoca da obra. $\mathrm{Na}$ realidade, há estudiosos que defendem que o opúsculo terá sido escrito na fase inicial da vida do polígrafo, enquanto outros sustentam precisamente a tese contrária. Pese embora a pertinência relativa dos argumentos, afigura-se talvez mais provável, em termos de cronologia relativa, uma datação compreendida entre a composição da Vida de

${ }^{4}$ Sinopse mais alargada em Lo CAscio (1997), 7-11 e 89-92.

${ }^{5}$ Bem visível nas indicaçóes de loci paralleli, que são abundantes nas notas à tradução, mesmo sem pretenderem ser exaustivas. 
Sólon (datável entre 97 e 110 da Era cristã) e o ano da morte de Plutarco (127).

Antes de se dar por terminada esta primeira análise, convirá ponderar ainda uma outra crítica que é por vezes aventada para contestar a autoria do opúsculo: o facto de o encontro das figuras que participam no banquete suscitar dificuldades cronológicas incontornáveis. As personalidades que possuem uma existência histórica confirmada por outras fontes (de resto a maioria) terão vivido entre os sécs. VII e VI a.C. e o encontro tenderia a datar-se na primeira metade do séc. VI. Ainda assim, não é possível encontrar uma data que permita harmonizar os reinados e períodos de vida de todos os participantes. Este facto, inegável, levou portanto a que alguns estudiosos considerassem indigna de Plutarco uma obra com tais características. A crítica, porém, é infundada e indicia, de certa forma, uma aparente incompreensão da essência da tradição ligada ao Septem Sapientium Conuiuium, que em si mesmo constitui uma irrealidade histórica, na medida em que, apesar de alguns dos Sábios envolvidos poderem ter entrado em contacto uns com os outros, eles não se reuniram seguramente num banquete como o que vem descrito. De resto, que Plutarco estava consciente deste tipo de dificuldades mostra-o a forma como, na biografia de Sólon, considera o famoso encontro entre o estadista e Creso da Lídia, em termos que será vantajoso evocar (Sol. 27.1):

Quanto ao seu encontro com Creso, alguns são de opiniâo que náo passa de uma invençấo, argumentando com 
a cronologia. Pela minha parte, contudo, um relato assim famoso, atestado por tantos testemunhos e, o que é mais importante, conforme ao carácter de Sólon e digno da sua magnanimidade e sabedoria, náo me parece que seja de o pôr de lado à conta de uns quadros cronológicos, que tantos estudiosos procuraram, até hoje, corrigir, sem que tenham conseguido reduzir as contradiçôes a algum resultado que eles próprios aceitem.

Ao referir a polémica que envolvia a célebre conversa entre Sólon e Creso, o biógrafo de Queroneia acaba por indicar, precisamente, as razóes que continuavam a justificar o registo e transmissáo daquela famosa entrevista: o elevado interesse moral que caracterizava o episódio. É idêntico, precisamente, o enorme potencial ético que acompanha a tradição dos Sete Sábios, enquanto repositório de um legado civilizacional que foi conhecendo múltiplas evoluçóes ao longo dos tempos, exactamente para melhor servir os interesses formativos de cada autor e da sua época. Por conseguinte, as dificuldades cronológicas não são impedimento para afirmar a autoria de um tratado que deriva de uma amplíssima tradiçáo literária e popular, ainda que assentando, em si mesmo, numa irrealidade histórica. É sobre essa tradição que será vantajoso falar em seguida, de maneira a enquadrar devidamente o Septem Sapientium Conuiuium. 


\section{A literatura de Sentenças}

A literatura gnómica ou de sentenças conheceu uma grande fortuna na antiguidade e a sua origem perde-se na própria raiz dos tempos. ${ }^{6}$ De facto, são inúmeros os exemplos de obras em que nos aparece determinada personalidade a aconselhar uma outra sobre a melhor forma de actuar. Este esquema de base conhece muitas formulaçóes e variantes. Duas das mais frequentes consubstanciam-se na figura do sábio que orienta um soberano sobre o tipo de conduta a adoptar ou, na sua versão mais familiar, na imagem do pai que procura zelar pela formação do filho, dispensando-lhe os conselhos que a vida ensinou. $\mathrm{O}$ Oriente Próximo fornece-nos um amplo espectro de escritos com este cariz e vamos encontrá-los também em inúmeras outras literaturas, sem que isso implique necessariamente uma relação de dependência directa, já que ideias semelhantes podem ter sido desenvolvidas por povos distantes uns dos outros e de forma autónoma. ${ }^{7}$ De resto, que este modelo simples continua activo e funcional, mostra-o uma infinidade de filmes produzidos pela indústria da sétima arte, onde a figura do mestre (com frequência industriado em 'artes orientais', assimiladas com um grau variável

${ }^{6}$ Já abordámos noutras ocasiôes a tradiçâao da literatura gnómica e sua relação com o Banquete dos Sete Sábios. Os resultados desses diferentes ensaios foram reunidos em LEÃo (2006); parte da argumentaçấo entâo desenvolvida é recuperada nas páginas que se seguem.

${ }^{7}$ Para um conspecto deste tipo de escritos moralizantes, vide WeST (1997). 
de eclectismo e rigor) prossegue a nobre missão de esclarecer e formar quem com ele se cruza.

No domínio da literatura grega, que agora nos ocupa mais em particular, o influxo deste tipo de material é detectável desde muito cedo também. Evocaremos apenas alguns exemplos, que ajudarão a atestar esta realidade bem conhecida dos estudiosos da antiguidade clássica. Em Homero, basta pensar na figura de Nestor, que se destaca pela ponderação das suas palavras, em particular na Ilíada. De resto, ele e outros seis guerreiros formavam uma espécie de conselho mais restrito de Agamémnon, o comandante-chefe da coligação grega que integrou a expedição a Tróia. ${ }^{8}$ Inesquecível é também o quadro dos anciãos que rodeavam Príamo e que, afastados embora dos combates devido ao peso da idade, mereciam, na qualidade de oradores, ser comparados ao delicado canto das cigarras. ${ }^{?}$

No caso dos Trabalhos e Dias de Hesíodo, o mesmo esquema conhece um aproveitamento ainda mais significativo. Sem querermos retomar agora a debatida questão da eventual influência directa de textos sumérios, babilónios ou egípcios sobre esta obra, o certo é que a sua estrutura de base assenta no tema do conselheiro. Uma das notas de novidade de Hesíodo parece residir, precisamente, no facto de o destinatário das suas admoniçôes ser não um rei ou um filho, mas o próprio irmão (Perses), a quem procura reconduzir ao bom caminho, pese embora o facto de este haver tentado apoderar-se

${ }^{8}$ Cf. Iliada, 2.400-409.

${ }^{9}$ Iliada, 3.146-152. 
da parte que lhe cabia na herança paterna. ${ }^{10}$ Além dos inúmeros preceitos e sentenças, que têm presença obrigatória em textos de carácter gnómico, Hesíodo serve-se também de outras estratégias expositivas que conhecerão igualmente grande fortuna na literatura sapiencial e que iremos reencontrar, por isso mesmo, no Banquete dos Sete Sábios: a fábula e o mito. ${ }^{11}$

O facto de, na Ilíada, Agamémnon aparecer rodeado de um grupo de sete homens da sua confiança está ainda longínquo da lenda que tenderá a fixar um colégio de Sete Sábios, a quem eram atribuídas sentenças memoráveis, proferidas no decurso de encontros com personalidades igualmente famosas. $\mathrm{O}$ contexto histórico que envolve algumas dessas figuras (como Tales, Sólon, Creso) sugere que a tradição terá começado a delinear-se durante a Época Arcaica, em particular entre os sécs. VII e VI a.C. A este facto não será alheia a circunstância de, ao longo daquele período, a Grécia haver experimentado grandes tensóes políticas e sociais, que foram acompanhadas pelo surgimento da figura dos legisladores e de governos autocráticos, bem como por intensas relaçóes com a Pérsia e a Ásia Menor, cuja opulência económica exercia sobre o imaginário grego

${ }^{10}$ Ainda assim, em alguns momentos Hesíodo também se dirige aos reis, para exortá-los a respeitar a justiça de Zeus; e.g. Trabalhos e Dias, 248-273.

${ }^{11}$ Referimo-nos à fábula do falcão e do rouxinol (Trabalhos e Dias, 202-212) e aos mitos de Pandora (42-105) e das Cinco Idades (106-201). Para uma sinopse do aproveitamento da tradição gnómica noutros autores gregos, desde a Época Arcaica até ao período romano, vide WeHrLI (1973); Rodríguez Adrados (1996) 130-137. 
tanto um sentimento de admiraçáo como de censura, por vezes acintosa.

Não obstante a relativa antiguidade cronológica de certos aspectos ligados à vivência de figuras que viriam a ser contadas entre os sapientes, é em Heródoto que podemos surpreender os primeiros assomos literários desta lenda. De resto, a imagem do conselheiro acaba por ser um Leitmotiv na obra do historiador de Halicarnasso. É o que se verifica, por exemplo, em relação a personalidades como o ateniense Sólon e Âmasis, o último grande faraó da dinastia saíta, que partilham entre si o papel de conselheiro ponderado. ${ }^{12}$ Da mesma forma que Sólon avisa Creso, rei da Lídia, contra a imprudência de ignorar a constante mutabilidade das coisas humanas (1.32.1-9), o faraó aconselha o tirano de Samos, Polícrates, a interromper a sua perigosa carreira de sorte, desfazendo-se de algum pertence que considerasse precioso, pois estava consciente de como a divindade era invejosa da fortuna dos homens (3.40.2). Ao contrário de Creso, cuja incompreensão do profundo significado das palavras do hóspede ateniense o lança no caminho da desgraça, Polícrates acatou o conselho do monarca egípcio, atirando ao mar um anel com uma esmeralda, de que muito gostava. Mas essa mesma jóia acabaria por lhe voltar às mãos no bucho de um grande peixe que um pescador lhe oferecera. Ao tomar conhecimento disto, o faraó compreendeu que náo podia ter um

12 Lattimore (I939), 24, coloca Âmasis na galeria dos conselheiros trágicos, que, além de Sólon, integra também Bias, Pítaco e até o próprio Creso (junto de Cambises), mas cujo representante mais acabado se encontra na pessoa de Artábano. 
fim feliz quem era tão aventurado a ponto de recuperar um objecto de que se havia desfeito e, assim, rompeu os vínculos de hospitalidade que o ligavam ao tirano, a fim de não ser arrastado pela desgraça que certamente iria atingir Polícrates. ${ }^{13}$ Embora Âmasis também vá ficar ligado ao ciclo dos Sete Sábios, ${ }^{14}$ a realidade é que, tanto em Heródoto como na tradição posterior, se destacam em particular as entrevistas patrocinadas por Creso e os conselhos que ele recebe de figuras como Tales (1.74.2; 75.3-4), Bias (ou Pítaco, 1.27.1-5) e Sólon (1.29-32). Os contornos que envolvem a relação com este último constituem o relato mais significativo de todos, a ponto de atingir o estatuto de relato paradigmático da forma como o diálogo entre um sábio grego e um monarca oriental poderia ser abordado. ${ }^{15}$

A importância de Creso na génese da tradição dos Sete Sábios vai ao encontro da fama que o soberano gozava entre os Gregos e à qual não será alheia, pela certa, a influência délfica, facto que facilmente se compreende se aceitarmos a historicidade das magníficas oferendas feitas ao oráculo pelo chefe lídio. ${ }^{16}$ Para mais, algumas

${ }^{13}$ Pormenores em 3.39-43. Para outras informaçôes sobre Âmasis, vide $2.154 .3 ; 2.162$ e 2.169 .

${ }^{14}$ Conforme se verá na análise ao Conuiuium de Plutarco (infra secção 5).

${ }^{15}$ Heródoto menciona também Quílon (1.59.2-3), Periandro $(1.20 ; 23)$ e o cita Anacársis (4.76-7). Este último virá a integrar o círculo dos sábios; a inclusão deste 'bárbaro' constitui não apenas uma nota de significativa imparcialidade, como permitirá ainda criticar certos aspectos da cultura grega, através dos olhos de um estrangeiro não maculado ainda por certos vícios da civilização. Vide infra secção 5.

16 Cf. Heródoto, 1.50-51. Em reconhecimento, os Délfios 
das famosas máximas inscritas no átrio do templo de Apolo eram atribuídas aos sapientes que passaram pela sua corte, de modo que os conselhos de moderação que vemos, por exemplo, aplicados na conversa entre Sólon e Creso se confundem com a própria moralidade do oráculo. ${ }^{17}$ Por outro lado, embora a indicação do número sete ainda esteja ausente em Heródoto, será essa a fórmula adoptada para designar os sapientes no seu conjunto. ${ }^{18}$ Ora é bem conhecida a importância que este algarismo possui em muitos outros relatos e culturas, mas não se afigura improvável que ele acuse, também por esta via, alguma relação com os interesses délficos. De facto, este era, precisamente, o dia do aniversário de Apolo (sete do mês de Byzios, em Fevereiro-Março), razão pela qual, de início, as consultas seriam ministradas exclusivamente nessa data e só depois, para atender à grande afluência, se estenderiam a outras alturas. ${ }^{19}$

outorgaram a Creso e aos Lídios privilégios especiais (1.54.2): a promanteia (prioridade na consulta do oráculo entre elementos do mesmo grupo, neste caso entre os Bárbaros); a ateleia (isenção de pagamento do imposto preliminar para a consulta do oráculo); proedria (lugar reservado nos espectáculos, geralmente nas primeiras filas) e ainda o direito de se tornarem cidadãos de Delfos.

${ }^{17}$ E.g. Platão, Cármides, 164d-165a; Pausânias, 10.24.1; Diógenes Laércio, 1.63 .

18 Heródoto refere-os apenas de maneira indeterminada (1.29.1): "passam por Sardes, entáo no cume da sua riqueza, todos os demais sábios da Hélade que nessa altura viviam, levados cada um por seu motivo".

19 É tentadora, igualmente, a hipótese de influência oriental, pois no poema de Gilgamesh da antiga Babilónia alude-se a um grupo de sete homens sábios que vieram ajudar na construçáo das muralhas da cidade. Em todo o caso, já no início desta análise chamávamos a atenção para a necessidade de ter em conta que ideias semelhantes podem ocorrer em lugares diferentes, sem que isso 
Em suma: desta breve resenha, afigura-se legítimo reter, antes de mais, que a imagem do sapiens constitui um dos grandes temas da própria tradição popular, tendo conhecido uma ampla difusão na antiguidade mais remota. Na literatura grega, a sua presença surpreende-se desde Homero, mas os indícios da fixação de um grupo de figuras de contornos histórico-lendários, que marcaram o imaginário grego entre os sécs. VII-VI, notam-se, pela primeira vez, em Heródoto. Embora a lenda não tenha ainda o perfil bem definido, na obra do historiador, notam-se já alguns aspectos que lhe são característicos: a marca de certas zonas de influência, como a Iónia (Pítaco, Bias e Tales), Atenas (Sólon) e o Peloponeso (Quílon, Periandro); o papel de Delfos, enquanto elo de ligação entre estas figuras. ${ }^{20} \mathrm{~A}$ partir daqui, o cânone tenderá a estabelecer -se, náo deixando, porém, de ser enriquecido com novos contributos e desenvolvimentos. É esse caminho que nos propomos evocar rapidamente na próxima secção, para nos determos, com mais pormenor, no contributo de Plutarco.

\section{A literatura de banquete}

Embora Heródoto constitua o primeiro testemunho literário a acusar a génese de um grupo estável de sapientes e a estabelecer até o modelo para alguns dos encontros mais famosos, é no Protágoras (343a) de Platão que se encontra a primeira relação completa dos

${ }^{20}$ Oportunas as observaçóes de Busine (2002) 17-27, esp. 27. 
Sete Sábios. As figuras escolhidas são Tales, Pítaco, Bias, Sólon, Cleobulo, Míson e Quílon. Segundo o filósofo, o motivo que justificara a sua reunião teria sido a vontade de consagrar a Apolo certas máximas, como primícias da sua sabedoria. A referência directa ao templo oracular ajuda a sustentar a hipótese de que o encontro terá acontecido em Delfos, se bem que o passo seja um tanto ambíguo, já que se afirma que esse era o destino das sentenças e náo propriamente o ponto de reunião. Por isso, a hipótese de Sardes também seria oportuna, dada a estreita ligação entre Creso, a figura dos sábios e a ética apolínea. Em todo o caso, a tradição posterior acabou por conceber estas e outras variantes, conforme demonstra um esclarecedor passo de Diógenes Laércio, que valerá a pena evocar (1.40):

Ora Arquetimo de Siracusa descreveu a sua [dos Sete Sábios] reuniáo na corte de Cípselo, na qual afirma ele próprio ter participado; já Éforo colocou-a na de Creso, sem a presença de Tales. Alguns afirmam que eles se juntaram no Paniónio, em Corinto e em Delfos.

Não obstante a informação de Diógenes, desconhece-se hoje a natureza dos trabalhos mencionados e o próprio Plutarco, na lista que fornece da literatura ligada ao tema do banquete, ${ }^{21}$ náo refere nenhum deles, se bem que essa enumeração se prenda com obras de carácter filosófico, facto que talvez explique a omissão. Em todo o caso, o testemunho do doxógrafo, agora

${ }^{21}$ No banquete, $612 \mathrm{~d}$. 
em análise, mostra a atenção que o tema despertou na literatura produzida entre a Época Clássica e a altura em que o autor esteve activo, na viragem do séc. II para o séc. III da nossa Era. Na verdade, Diógenes representa um momento da tradição em que as diferentes abordagens da questão se encontravam já cristalizadas e disso fornece abundantes exemplos na sua obra. No Livro I, depois do proémio e antes da consideração dos filósofos propriamente ditos, o biógrafo recorda, ao longo de uma centena de capítulos, inúmeros aspectos ligados à existência daqueles homens que, desde os tempos de antanho, haviam sido considerados sophoi. ${ }^{22}$ Destes, é a Tales e a Sólon que analisa com maior cuidado, facto que espelha o peso que estas figuras detinham já na lenda. ${ }^{23}$ Ao tecer a biografia destas personalidades, Diógenes está, naturalmente, a par das variantes da tradição, que opta, de resto, por explorar, fornecendo, assim, um elucidativo conspecto dos diferentes estádios da sua evolução, que será pertinente recordar (1.41-42):

Discute-se também qual o seu número. Leândrio, de facto, em vez de Cleobulo e de Míson, optou por Leofanto, filho de Górsias, de Lébedos ou de Éfeso, e pelo cretense Epiménides; já Platão, no Protágoras, faz entrar Míson para o lugar

${ }^{22}$ Conforme ele mesmo esclarece (1.122), antes de fazer a transição para a filosofia iónica, de que Tales, uma das figuras evocadas também como sábio, fora o iniciador.

${ }^{23}$ Os capítulos encontram-se distribuídos na seguinte proporção: Tales (22-44); Sólon (45-67); Quílon (68-73); Pítaco (74-81); Bias (82-88); Cleobulo (89-93); Periandro (94-100); Anacársis (101-105); Míson (106-108); Epiménides (109-115); Ferecides (116-122). 
de Periandro; Éforo substitui Míson por Anacársis; outros ajuntam ainda Pitágoras. Dicearco regista quatro nomes que também reconhecemos - Tales, Bias, Pítaco, Sólon - e refere outros seis (de entre os quais selecciona três): Aristodemo, Pânfilo, o lacedemónio Quílon, Cleobulo, Anacársis e Periandro. Alguns acrescentam Acusilau, filho de Cabas ou de Escabras, natural de Argos. Mas Hermipo, no Sobre os Sábios, alinha dezassete, a partir dos quais diferentes pessoas formam grupos diferentes de sete. São eles Sólon, Tales, Pítaco, Bias, Quílon, Míson, Cleobulo, Periandro, Anacársis, Acusilau, Epiménides, Leofanto, Ferecides, Aristodemo, Pitágoras, Laso, filho de Carmântides ou de Sisímbrino ou, de acordo com Aristóxeno, de Cábrino, natural de Hermíone, e Anaxágoras. Hipóboto, na Lista dos Filósofos, alinha Orfeu, Lino, Sólon, Periandro, Anacársis, Cleobulo, Míson, Tales, Bias, Pítaco, Epicarmo e Pitágoras.

O texto quase dispensa mais comentários, pois é, por si mesmo, bem ilustrativo da riqueza da tradição ligada aos Sete Sábios, bem como das possibilidades de escolha e combinação dessas figuras. Ao grupo pertenciam inclusive tiranos como Periandro, que, mesmo quando náo ocupavam o posto de sapiente, poderiam desempenhar um papel igualmente importante ao patrocinarem reunióes de sophoi. ${ }^{24}$ Diógenes, que não pretende descrever um encontro com estas personalidades, evita a obrigação de eleger o tradicional número de sete, pelo que opta por traçar a biografia das onze figuras que lhe despertavam

${ }^{24}$ No passo em análise, Diógenes não refere Pisístrato, embora reconheça, ao encerrar a biografia das figuras que escolhera, que alguns autores o catalogam também entre esses homens ilustres (1.122). 
maior interesse ou sobre as quais circularia maior cópia de informação. $\mathrm{O}$ delineamento da sua existência segue um esquema relativamente estável. Os elementos constantes prendem-se com os três pontos fundamentais na vida: nascimento, maturidade (akme) e morte. Os traços sujeitos a maior variação ligam-se às sentenças e opinióes conotadas com a personagem retratada. ${ }^{25}$

\section{Rituais DE COMENSAlidADE}

Antes de passarmos ao caso de Plutarco, que nos motivará uma reflexão maior, importa retomar um factor ligado ao contributo de Platão. Ainda mais significativo do que o aspecto episódico de ter sido ele o primeiro a apresentar uma lista de Sete Sábios, que se haviam reunido com um objectivo específico, está o facto de o filósofo ter criado um modelo de exposição que conhecerá, igualmente, inúmeras imitações e aproveitamentos. Referimo-nos ao diálogo filosófico e, em particular, à forma adoptada no Banquete. Para melhor ponderarmos a importância dessa criação literária, importa reflectir um pouco sobre o lugar que o próprio symposion ocupava na cultura grega. ${ }^{26}$

$\mathrm{O}$ acto ritualizado de partilhar a comida e a bebida pode revelar-se muito importante, na medida em que

${ }^{25}$ Estes exemplos de sabedoria popular designam-se geralmente por termos como gnome, apophthegma, apomnemoneuma, chreia. Sobre as características, origem e tradição deste tipo de literatura e sua utilização na obra de Diógenes, vide Kindstrand (1986) 217-243; Gigante (1986) 16-18.

${ }^{26}$ Nesta breve sistematização, iremos aproveitar algumas das ideias desenvolvidas por Murray (1994). 
constitui uma excelente oportunidade para vencer barreiras e firmar laços de natureza social, antes de mais, mas também de cariz político e religioso. De resto, as ocasiōes em que a refeição comum era praticada, em termos gerais, na Grécia da Época Arcaica e Clássica ajudam a tornar mais clara esta realidade. Salvo algumas notáveis excepçóes (como o oráculo de Apolo em Delfos e o culto a Perséfone e Deméter em Elêusis), a religião grega caracterizava-se por não ter uma casta sacerdotal fixa, pelo que as obrigaçóes religiosas acabavam por recair na esfera de competência de certos magistrados públicos. Desta forma, os festivais religiosos assumiam um carácter de 'Estado', enquanto elucidativo sinal de civismo, onde a refeição em conjunto poderia ocupar um posto importante. Aliás, em Atenas, uma das formas de reconhecimento público consistia em garantir a alguém a refeição a expensas da cidade no Pritaneu, na companhia de outros membros ilustres da pólis. $\mathrm{Na}$ sociedade estratificada e estanque de Esparta, o acto de comer em conjunto (syssitia) constituía uma forma institucionalizada de fortalecer os laços entre os cidadáos, cuja influência se sobrepunha ao domínio privado da célula familiar. A vertente de lazer, que acompanhava também grande parte desses momentos, acabaria por traduzir-se em criaçóes culturais, que encontravam nesse espaço um enquadramento de eleição. Se não quisermos entrar no domínio das provas desportivas, basta pensar em manifestaçôes artísticas como a música, a poesia, a retórica e a discussão político-filosófica, para vermos plenamente justificadas as implicaçóes culturais destes eventos. ${ }^{27}$

${ }^{27}$ Não é por acaso que, ao longo do último quartel do séc. 
Deixámos para o fim aquele tipo de refeição que interessa mais aos nossos objectivos: o symposion privado. Em teoria, qualquer pessoa com alguns recursos poderia promover uma reunião informal com os amigos. No entanto, os gastos ligados a esta forma de diversão, bem como o tempo que obrigava a despender, fazem com que o banquete seja uma realidade conotada, preferencialmente, com o estilo de vida aristocrática, realidade que acarreta algumas consequências dignas de nota. Antes de mais, saliente-se o facto de constituir uma comensalidade inter pares e de, portanto, ser mais fácil promovera igualdade de expressão; depois, a contingência de ocorrer num 'espaço masculino' (andron), aspecto que poderia causar alguma estranheza noutras culturas. ${ }^{28}$ Isto não implica que as mulheres estivessem ausentes, se bem que a sua assistência náo abonasse muito em favor da respectiva reputação. Na realidade, o symposion podia cumprir também a função de iniciar um jovem a vários níveis, entre eles a actividade sexual. Daí que a relação de pederastia fosse uma presença assídua nestes espaços; ${ }^{29} \mathrm{o}$ mesmo se diga em relação à prática do amor livre, patrocinado por mulheres de moral duvidosa

XX, se intensificaram os estudos relativos ao contexto de apresentação da poesia grega, bem como às características da audiência que acompanhava a execução da lírica coral, monódica e elegíaca.

${ }^{28}$ Conforme nos dá conta Cícero (Contra Verres, 2.1.26.66), ao apresentar as desculpas que um grego do séc. I a.C. dava a um oficial romano, interessado em seduzir a filha do anfitrião: «não é costume dos Gregos permitir que as suas mulheres se reclinem num conuiuium de homens».

${ }_{29} \mathrm{Tal}$ como acontecia nos ginásios, igualmente assimilados a ocupaçóes de natureza aristocrática. 
(hetairai), contratadas especificamente para a animação do banquete, juntamente com as flautistas e bailarinas.

Todos estes factores contribuíam para que o symposion constituísse um meio privilegiado para reforçar laços de amizade pessoal e ideológica, traduzidos em lealdade entre os elementos de determinado grupo (hetaireia), que poderiam revelar-se determinantes na altura de solucionar problemas pessoais ou de perseguir uma carreira política. Aliás, estes propósitos viam-se facilitados pelo papel que o vinho detinha no banquete e que acabava por ser até mais importante do que a refeição propriamente dita, conforme se deduz do sentido primitivo do próprio termo symposion ('beber em conjunto'). ${ }^{30}$ A bebida aproximava os convivas, da mesma forma que o espaço relativamente limitado da sala de jantar e o facto de se encontrarem reclinados ajudavam a concentrar as atençóes dos comensais. Por isso, era fundamental que o vinho fosse misturado com água, a fim de permitir o prolongamento da conversa e da diversão, sem que o convívio descambasse em excessos, colocando em risco a harmonia do encontro. ${ }^{31}$

${ }^{30}$ Já o latim conuiuium coloca a tónica na partilha do espaço ('viver em conjunto') e, em consequência, na ideia de 'compartir a refeição'. Ao comentar a etimologia do termo, Cícero (Catão Maior, 13.45) acentua bem essa diferença relativamente aos Gregos. Nas Tusculanas, 5.41.118, é ainda mais expressivo, ao referir «aquela norma que se observa nos conuiuia gregos: 'ou se póe a beber ou se póe a mexer' (aut bibat aut abeat)».

${ }^{31}$ Beber vinho puro era, aliás, uma característica distintiva dos bárbaros; por outro lado, a partir da Época Helenística, a intensificação dos contactos com a Macedónia e Roma levou a que a discussão ligada ao ritual da refeição propriamente dita (deipnon) viesse a ser encarada também com importância 
Mesmo com estes cuidados, o banquete comportava, por vezes, uma dimensão mais violenta, em particular no seu termo, sobretudo quando resultava do convívio a necessidade de cometer alguma prova que ajudasse a cimentar os laços de lealdade (pistis) entre os companheiros de mesa. Nas vésperas da partida da armada para a Sicília (em 415 a.C.), Atenas viveria momentos de escândalo e de pavor, com dois sacrilégios que teriam sido perpetrados no contexto do symposion: a mutilação das estátuas de Hermes e a paródia aos Mistérios de Elêusis. Embora o excêntrico aristocrata Alcibíades só pareça ter estado envolvido na questão dos Mistérios, as fontes espelham alguma ambiguidade favorável à confusão entre os dois sacrilégios, que poderia ter sido aproveitada pelos inimigos do estadista. ${ }^{32}$ Já os antigos sentiram dificuldades em esclarecer os reais contornos do escândalo, que ficou para a posteridade como exemplo dos perigos do exibicionismo destrutivo, fosse ou não motivado por objectivos políticos de maior alcance.

Depois destas breves notas relativas ao posto que o banquete ocupava na cultura grega, chegou a altura de regressar a Platáo e de procurar entender os motivos que justificaram este pequeno excurso num trabalho em que se pretende reflectir sobre a tradição dos Sete Sábios. Os inícios da literatura de banquete podem encontrar-se já

crescente. Vide Murray (1994) 5-6; Stadter (1999).

${ }^{32}$ Em fontes mais tardias, como Diodoro (13.2.3-4; 5.1), a ligação aos dois sacrilégios encontra-se já bem patente. No entanto, Tucídides (6.27-28.2) distingue os dois crimes, mas deixa entrever (6.28.2) que, aos olhos dos inimigos, Alcibíades seria suspeito de estar por detrás também da mutilação dos Hermes ou pelo menos de lhe dispensar simpatias. 
na descrição de convívios divinos e humanos, que ocorrem com alguma frequência em Homero. ${ }^{33}$ Contudo, ao imaginar o Banquete em casa do jovem poeta trágico Ágaton, onde várias personalidades se tinham reunido para discutir os poderes de Eros (destacando-se entre elas a figura de Sócrates), Platão havia de tornar-se no primeiro autor a verter o ambiente ritualizado do symposion numa obra literária. Com este passo, fixa o modelo para uma forma de utilização do diálogo filosófico em contexto de banquete que será depois retomada por inúmeros autores. ${ }^{34}$

Ora é precisamente neste ponto que a questão volta a encontrar-se com o tema dos sapientes. De facto, entre os textos relativos a esta tradição, aquele que será porventura mais significativo é o Septem Sapientium Conuiuium de Plutarco. Que a matriz platónica está na génese deste opúsculo do biógrafo de Queroneia é um facto mais do que conhecido dos estudiosos, pelo que nos dispensamos de retomar esse problema. ${ }^{35}$ Menos evidente se afigura, no entanto, a hipótese de existir uma ou várias obras de permeio, que tivessem explorado já a conjugação do encontro dos Sete Sábios com a realização de um banquete e servissem, portanto, de modelo a Plutarco. Em si, a ideia revela-se bastante plausível, mas falta, no entanto, um aspecto fundamental: um

${ }^{33}$ E.g. Iliada, 1.595-611; Odisseia, 4.15-19.

${ }^{34}$ Para os nossos objectivos, não se afigura pertinente discutir se o Banquete de Xenofonte é ou não anterior ao de Platão, já que, dos dois, foi claramente este último que exerceu a influência mais determinante.

${ }^{35}$ De resto já sumariamente abordado neste mesmo trabalho (supra secção1). 
exemplo claro e inequívoco de que as coisas se passaram desse modo. ${ }^{36}$ É certo que o texto de Diógenes Laércio anteriormente comentado (1.40) aponta nessa direcção, mas isso náo impede liminarmente que o Symposion de Plutarco tenha sido a fórmula encontrada pelo autor a fim de conseguir margem de relativa inovação, dentro de uma tradição já muito saturada por tratamentos aná$\operatorname{logos} .^{37}$

\section{O Banquete dos Sete Sábios de Plutarco}

Um dos primeiros anacronismos que se pode apontar ao Banquete dos Sete Sábios reside no facto de Plutarco pressupor, como atrás se dizia, a contemporaneidade dos vários sapientes envolvidos. Pensar que o autor não tinha consciência do erro está fora de questáo, conforme se pode constatar na biografia que fez de Sólon, um dos participantes no banquete. ${ }^{38} \mathrm{Se}$, nesse ponto, o polígrafo defendia o relato do encontro com o soberano lídio em

${ }^{36}$ Rodríguez Adrados (1994), 139-140, sustenta que o tema original da relação rei/sábio, combinado com o esquema do banquete platónico, foi modificado em ambiente cínico (possivelmente logo a partir do séc. IV a.C.) e expandido através do contributo de material antiquário e dos géneros antológicos helenísticos. Seria esta amálgama de contributos que teria influenciado Plutarco; o estudioso vai ainda mais longe e sugere como provável precedente a modificação do diálogo socrático por Menipo.

${ }^{37}$ Ainda assim, no prólogo do Conuiuium (146b), Díocles, o narrador, propóe-se apresentar a versão correcta do symposion, já que circulavam outros relatos sem fundamento. Embora esta afirmação possa constituir um mero expediente narrativo, não é improvável que seja uma alusão a tratamentos anteriores e, de certa maneira, semelhantes ao que Plutarco agora adoptava.

${ }^{38}$ Cf. Vida de Sólon, 27.1. Já antes se comentou este passo (supra secção 1). 
nome do seu peso ético, mais pertinente essa explicação se torna neste caso, já que o encontro dos Sete Sábios representa, em si mesmo, uma ficção literária. Por outro lado, Plutarco está, naturalmente, a seguir uma tradição enraizada havia muito tempo no pensar comum, que o obrigava a colocar o diálogo num passado distante. ${ }^{39}$

O convite para o encontro foi endereçado pelo tirano Periandro, tendo como destinatários os seguintes sábios: Sólon, Tales, Anacársis, Bias, Cleobulo, Pítaco e Quílon. No entanto, aparecem muitas outras figuras no symposion, inclusive femininas, ajudando a construir a originalidade do opúsculo, conforme veremos mais adiante. As outras personagens não gozam todas, porém, do mesmo nível de intervenção de que dispóem os sapientes. ${ }^{40}$ Contudo, no queà identidade dos Sete Sábios diz respeito, Plutarco mostra-se bastante próximo do colégio definido por Platão: exclui, como ele, Periandro, mas coloca Anacársis no lugar de Míson. ${ }^{41}$ A eliminação de Periandro do núcleo dos sábios justifica-se, pela certa,

${ }^{39}$ Facto que constitui, de resto, uma nota de excepção dentro dos seus escritos; o único outro caso é o tratado Sobre o génio de Sócrates. Cf. Aalders (1977) 28-29 e n. 7.

${ }^{40}$ De facto, são dezassete as personagens, sem contar com Gorgo, irmão de Periandro, que entra na parte final do symposion (160d). Contudo, o facto de algumas das figuras tomarem a palavra de forma tradicional e segundo uma ordem fixa, na primeira parte do diálogo (151e, 154d, 155c), permite identificar quais eram, efectivamente, os Sábios. Vide Defradas-Hani-Klaerr (1985) 179-181.

${ }^{41}$ Possivelmente na esteira de Éforo, já que a lista de Demétrio de Fáleron admitia a presença de Periandro; cf. supra Diógenes Laércio, 1.41. Noutro ponto (Sobre o E de Delfos, 385d-e), Plutarco refere a tradição, relativa às máximas de Delfos, que excluía tanto Periandro como Cleobulo, reduzindo o número de sábios a cinco. 
devido ao facto de ele ser tirano e de o opúsculo revelar uma animosidade de fundo em relação a esta forma de governo. Ainda assim, Cleobulo, autocrata de Lindos, continua a figurar entre os sapientes, embora detenha um papel bastante secundário e a sua presença deva explicar-se, também, pela intenção de colocá-lo junto da filha, Cleobulina. Em termos comparativos, Periandro acaba por desempenhar uma função mais importante, na qualidade de anfitriáo, ainda que a sua presença se vá desvanecendo, sobretudo a partir do momento em que se começa a fazer o elogio do regime democrático, a ponto de caber a Sólon a honra de fechar o banquete (164c-d). Nesta galeria, o caso de Pítaco é igualmente digno de nota, dado que, durante algum tempo, esteve à frente dos destinos de Mitilene com plenos poderes. Fê-lo, porém, na qualidade de soberano eleito pelo povo (aisymnetes) e, depois de ter acalmado o clima de dissensão civil, mostrou, como Sólon em Atenas, a prudência de abandonar o poder, com ele partilhando a fama de legislador. ${ }^{42}$

Em todo o caso, a presença de vários sábios conotados com regimes autocráticos deve constituir um sinal da antiguidade da tradiçáo que os contava nesse círculo. De facto, se é certo que, na viragem do séc. VII para o VI a.C., a tirania era um regime existente e até característico da época, o mesmo não se poderá afirmar a respeito da democracia, que só mais tarde daria os

${ }^{42}$ De resto, já Heródoto (1.27) e Platão (Protágoras, 338e-347a; Hipias Maior, 281c; República, 335e) lhe atribuíam um lugar de eleição entre os sapientes; sobre as leis que o celebrizaram em Mitilene e as máximas que terá proferido, vide Diógenes Laércio, 1.75. 
primeiros passos. Há portanto um anacronismo no debate quando os sábios defendem o governo popular, do tipo daquele que envolveu os nobres persas em considerações acerca da melhor forma de constituição. ${ }^{43}$ Desta maneira, a animosidade contra a tirania não deve fazer parte das fases iniciais da lenda. ${ }^{44} \mathrm{O}$ carácter odioso do termo é, sobretudo, uma consequência da acção dos Trinta Tiranos, que governaram Atenas em 404 e cuja actuação ficou marcada por uma violência extrema. Daí que em Platão já se note esse sentimento de crítica, que passaria à tradição posterior e conhece uma expressão clara no Conuiuium de Plutarco.

Sólon, Tales, Bias e Quílon pertenciam já ao núcleo estável dos Sete Sábios, além de terem a vantagem de não levantar os problemas que acabámos de analisar, pelo que evitaremos deter-nos sobre eles. Todavia, no que a Anacársis diz respeito, interessa reflectir com mais pormenor. Heródoto refere-se a ele na altura em que descreve os hábitos dos Citas e a aversão que estes nutrem por costumes estranhos, em particular se tiverem origem grega. Na versão do historiador (4.76), Anacársis é já apresentado com traços de sapiente, dado que, nas muitas terras por onde tinha viajado, deixara provas de elevada ponderação. De regresso a casa, Anacársis ficara impressionado com a festividade

${ }^{43}$ Relatado por Heródoto (3.80-82).

${ }^{44} \mathrm{Na}$ primeira ocorrência do termo (frg. 19 WeST de Arquíloco), a tirania é classificada de 'poderosa' e, mesmo na segunda metade do séc. $\mathrm{V}$, as palavras tyrannos e tyrannis aparecem usadas, ainda, com o sentido de 'rei, soberano', 'riqueza, poder', se bem que a cor semântica negativa também possa ocorrer. 
em honra da Magna Mater, que havia observado em Cízico, e comprometeu-se a instaurar o culto no seu país de origem, se conseguisse regressar a salvo. Já na Cítia, foi surpreendido a realizar esse ritual e viria a morrer às mãos do próprio irmão, o rei Sáulio. Desta forma, Anacársis tornava-se numa espécie de mártir da civilização grega. O mesmo Heródoto (4.77) apresenta ainda outra versão dos eventos, embora a considere uma invenção. De acordo com este segundo relato, Anacársis teria frequentado uma escola na Hélade a mando do próprio rei; ao regressar, informou-o de que os Gregos eram dados a todo o tipo de saber, com excepçáo dos Lacedemónios. Apesar disso, estes últimos eram os únicos que revelavam capacidade para falar e ouvir com acerto. Esta variante retira a Anacársis a fama de ser um entusiasta da cultura grega. No entanto, a preferência pela discrição e laconismo dos Espartanos criou nele uma aura de 'bom selvagem', habilitado para criticar a opulência da civilização. A imagem de sábio austero será aproveitada, em particular, pela escola cínica, que fará dele um símbolo do despojamento e um paladino das suas ideias filosóficas. ${ }^{45}$ Ao colocá-lo no symposion promovido por Periandro, Plutarco encontrava-se na linha do influxo tradicional. No entanto, a figura deste sábio 'bárbaro' ia também ao encontro do objectivo

${ }^{45} \mathrm{O}$ seu aspecto descuidado faria lembrar o do cínico Diógenes, pelo que os partidários desta escola chegaram mesmo a atribuir-lhe a autoria de uma série de cartas onde sustentaria os preceitos cínicos; Cícero (Tusculanas, 5.32.90) cita um fragmento dessa actividade epistolar, comum, de resto, a boa parte das figuras ligadas ao círculo dos Sete Sábios. 
de tornar o Banquete num espaço aberto à alteridade. Como tal, além da aristocracia grega maioritária, estava igualmente representada a sofisticação egípcia (através de Nilóxeno, enviado de Âmasis) e o nomadismo dos bárbaros do norte (Anacársis). ${ }^{46} \mathrm{~A}$ esta diversidade, vinham juntar-se ainda as marcas da sensibilidade feminina (Cleobulina) e de uma sabedoria mais popular (Esopo), sobre as quais falaremos de seguida.

\section{UMA SABEDORIA 'ALTERNATIVA' NO BANQUETE DOS SETE SÁBIOS}

Ao reflectirmos sobre o papel do symposion na literatura grega, chamávamos a atenção para o facto de o banquete ser, essencialmente, uma actividade conotada com o mundo masculino. Contudo, no Conuiuium imaginado por Plutarco estão presentes duas figuras femininas: Cleobulina e Melissa, esposa de Periandro. São ambas personagens mudas e ausentam-se antes do final do banquete, permitindo assim que a conversa evolua para tópicos mais densos (155d-e). Contudo, se a mulher do tirano acaba por ser apenas um adorno, a pessoa de Cleobulina/Eumétis obriga a maior ponderação e tem, por isso, dividido os estudiosos. Em primeiro lugar, a presença de mulheres poderia ser vista apenas como um sinal da época de Plutarco, onde a

${ }^{46}$ Plutarco serve-se também do cita para expor algumas das suas convicçóes éticas e filosóficas, nomeadamente em relação à melhor forma de organização política e doméstica (152a, 155a-c) e ao facto de ver na alma um instrumento de Deus (163d-f), como já atrás se comentou (supra secção 1), a propósito das aventuras de Aríon. Vide ainda Schmidt (1999) 260-261. 
influência de outras culturas faria com que a inclusão de mulheres 'sérias' no symposion fosse considerada uma escolha normal. Esta explicação simples revela -se oportuna, se bem que enfrente o óbice de, nas Quaestiones conuiuales, não se registarem participantes femininos. ${ }^{47}$ Por outro lado, nas Leis (780e), Platão regista que as mulheres podem juntar-se em refeiçóes públicas, mas não está a referir-se a banquetes mistos, o que invalida, naturalmente, a sua participação nos symposia usuais. Verificados estes condicionalismos, a opção de Plutarco de fazer entrar a figura de Cleobulina, ainda muito jovem, deve explicar-se talvez por outra via. Antes de mais, como novidade relativa e como forma de acrescentar ao ambiente algumas cenas quase domésticas, como é o facto de, logo à chegada a casa de Periandro, nos apresentar Cleobulina a tratar dos cabelos desgrenhados de Anacársis (148c-e). De alguma forma, parece dizer que o aspecto agreste do bárbaro cita estaria a ser modelado pela delicadeza de máos gregas. De resto, as palavras de Tales, que cumprimenta a jovem com familiaridade, acentuam precisamente essa impressão, se bem que com a ideia de que eram mútuas as vantagens daquela relação próxima com o bárbaro. A influência benéfica de Cleobulina projecta-se, ainda, sobre o pai, ajudando a dulcificar-lhe o carácter e a tornar o seu governo mais próximo do povo (demotikoteros);

${ }^{47}$ De facto, no passo (712e-f) que poderia ser apresentado para sustentar a posiçáo contrária, o que está em questão é mais o carácter vulgar do mimo do que a inclusão de mulheres e crianças no banquete. Vide Mossman (1997) 124-125; Pordomingo Pardo (1999) 389-391. 
desta forma, atenua-lhe o traço negativo de ser tirano de Lindos. ${ }^{48}$ Por último, Cleobulina contribui, também, para transformar o espaço do banquete numa cosmópolis dos vários tipos de sapiência: ela representaria, assim, uma sabedoria mais simples, permeada de intuição política e de humanidade, conforme se depreende das palavras que Tales profere a respeito dela. ${ }^{49}$

Para este mundo de sabedoria alternativa contribui ainda, grandemente, a figura de Esopo. Tal como Cleobulina, vários aspectos da sua vida têm como pano de fundo a lenda dos Sete Sábios, sem que nunca tenha sido considerado um deles. A sua presença no symposion deve-se, do ponto de vista da narrativa, ao facto de estar ao serviço de Creso, que o enviou quer à corte de Periandro quer ao oráculo de Delfos (150a). Este pormenor lança, de certa forma, alguma sombra sobre o desfecho da sua participação, já que, segundo os dados da lenda, Esopo sofreria uma morte violenta em Delfos, por haver desrespeitado os sacerdotes do oráculo e os habitantes da região, acusando-os de simples parasitismo. Com esta nota discreta, Plutarco parece acenar à polémica latente com o círculo dos sapientes, dada a estreita ligação destes últimos com a moralidade délfica. ${ }^{50}$ De resto, o facto de ser emissário de Creso serve de contraponto ao relativo desprezo que Sólon manifestara

${ }^{48} \mathrm{E}$ justifica o nome alternativo por que é conhecida: Eumétis ('avisada, prudente').

49 Vide Mossman (1997), 124-126, cujos argumentos seguimos, em parte, neste ponto da exposição.

${ }^{50}$ Cf. Heródoto, 2.134; Aristófanes, Vespas, 1446-1448. Vide ainda Defradas-Hani-Klaerr (1985) 184-186; García Gual (1994); vAN DijK (1999). 
em relação ao monarca lídio (155b) e que encontra eco também na biografia do estadista (Sol. 28.1). No Conuiuium, Esopo encontra-se sentado num escabelo, junto do poeta ateniense, que está reclinado e num plano superior (150a). Cruzam-se, assim, as identidades do aristocrata e do antigo escravo, num mesmo espaço, mas separados por uma sensibilidade e estatuto diferentes: a integração de Esopo dentro do grupo não chega, portanto, a ser total, se bem que não redunde nunca em tensão aberta. O fabulista fala diversas vezes ao longo do symposion e, em duas delas, toma o partido quer de Cleobulina quer de Periandro. No primeiro caso (154a-c), defende a jovem quando ela se abstivera de responder, por timidez, às palavras do médico Cleodoro, que lhe criticava a futilidade dos enigmas. A intervenção de Esopo é significativa, na medida em que, ao colocar-se ao lado de Cleobulina, está também a defender a mesma sabedoria popular que ele próprio representa. No segundo caso (152b-d), sai em auxílio de Periandro, que as tiradas anteriores dos sábios haviam, de alguma forma, isolado, já que exprimiam ideias contrárias à tirania. $\mathrm{Na}$ sua argumentação, Esopo entra novamente em discussão com Sólon, que se diverte com as palavras do antigo escravo, não o levando muito a sério. Contudo, esta intervenção ajuda a reforçar o carácter de Esopo enquanto representante das massas populares, que tiveram, de resto, um papel importante na instalação de tiranias, cujo governo assumia, geralmente, um cariz anti-aristocrático, protegendo, em consequência, as classes inferiores que constituíam a sua base de apoio. 
Desta breve análise feita ao opúsculo de Plutarco, resulta ainda assim claro que, embora o Banquete dos Sete Sábios seja, tal como a maioria dos episódios ligados à existência dos Sete Sábios, uma irrealidade histórica, partilha com este material de tipo lendário preocupaçôes éticas que justificam a sua apreciação como uma das mais curiosas expressóes do carácter fundacional da cultura clássica. Foi esse, de resto, o princípio desenvolvido pelas diferentes abordagens que, ao longo dos tempos, enriqueceram com novos contributos o longo e animado percurso da literatura gnómica. Ao recuperar e reescrever todo um legado civilizacional, de forma a colocá-lo ao serviço dos interesses formativos de cada época, a tradição dos Sete Sábios assume o estatuto de paradigma e torna-se, desta forma, num veículo privilegiado de paideia.

Delfim F. Leão 


\section{Bibliografia}

\section{EDIÇÓES CRÍTICAS, TRADUÇÓES E COMENDATÁRIOS}

Babbitt, F. C.: Plutarch. The Dinner of the Seven Wise Men in Moralia, II (London, 1956).

Lo Cascio, Ferdinando: Plutarco. Il Convito dei Sette Sapienti (Napoli, 1997).

Defradas, Jean: Plutarque. Le banquet des sept sages, texte et trad. avec introd. et notes (Paris, 1954).

Defradas, Jean, Hani, Jean \& Klaerr, Robert: Plutarque. Oeuvres Morales, II, texte établi et traduit (Paris, 1985).

Morales Otal, Concepción \& García López, J.: Obras morales y de costumbres (Moralia), II, introd. trad. y notas (Madrid, 1986).

Paton, W. R. \& Wegehaupt, I.: Plutarchi Moralia I, praefationem scr. M. PoHLEnz, editionem correctiorem curauit Hans Gä̈TNER (Leipzig, 1974), 300-338 e (addenda et corrigenda) 399-406 [o SSC é da responsabilidade de Paton e foi o texto de referência usado para a tradução].

\section{Estudos}

Aalders, G. J. D.: "Political thought in Plutarch's Convivium Septem Sapientium”, Mnemosyne 30 (I977) 28-39.

Alessandrì, Salvatore: "I viaggi di Solone", CCC 10 (1989) 191-224. 
Busine, Aude: Les Sept Sages de la Grèce antique. Transmission et utilisation d'un patrimoine légendaire, d'Hérodote à Plutarque (Paris, 2002).

Demarais, Laetitia: "Sages et souverain à l'épreuve du banquet: le Banquet des Sept Sages et la Lettre d'Aristée à Philocrates", in Plutarco e l'età ellenistica, ed. A. Casanova, (Firenze, 2005), 79-104.

Van Dijk, Gert-Jan: "Esopo, Plutarco, Platón y Aristóteles. La función de la fábula y el arte de la alusión”, in Plutarco, Platón y Aristóteles, eds. A. Pérez Jiménez, J. García López \& Rosa M. Aguilar (Madrid, 1999), 141-156.

Duplouy, Alain: "Lutilisation de la figure de Crésus dans l'idéologie aristocratique athénienne. Solon, Alcméon, Miltiade et le dernier roi de Lydie", $A C 68$ (1999) 1-22.

Fehling, Detlev: Die Sieben Weisen und die frühgriechische Chronologie. Eine traditionsgeschichtliche Studie (Bern, 1985).

García Gual, Carlos: "Esopo en Plutarco", in Estudios sobre Plutarco: ideas religiosas, ed. M. García Valdés (Madrid, 1994), 605-614.

Gigante, Marcello: "Biografia e dossografia in Diogene Laerzio”, Elenchos 7 (1986) 7-102.

Gómez Cardó, Pilar: "Ateneu i els set savis", in Homenatge a Miquel Dolç, Actes del XII Simposi de la Secció Catalana i I de la Secció Balear de la SEES (Palma de Mallorca, 1997) 199-204. 
"Cynicism and Hellenism in the Letters of Anacharsis and the Vita Aesopi”, Lexis 21 (2003) 319-332.

Kindstrand, Jan Fredrik: "Diogenes Laertius and the Chreia tradition”, Elenchos 7 (1986) 217-243.

LATTIMORE, Richmond: "The wise adviser in Herodotus", CPh 34 (I 939) 24-35.

LEÂO, Delfim Ferreira: "Plutarch and the dark side of Solon's political activity", Ploutarchos n.s. 1 (2003/2004) 51-62.

_ “A tradição dos Sete Sábios: o sapiens enquanto paradigma de uma identidade", in D. F. Leão, J. Ribeiro Ferreira e M. do Céu Fialho, Paideia e cidadania na Grécia antiga (Coimbra, 2006), 35-78.

Mossman, Judith: "Plutarch's Dinner of the Seven Wise Men and its place in symposion literature", in Plutarch and his intellectual world, ed. J. Mossman (London, 1997), 119-140.

Murray, Oswyn: "Sympotic history", in Sympotika. A symposium on the Symposion, ed. O. Murray (Oxford, 1994), 3-13.

Paladini, Maria Luisa: "Influenza della tradizione dei Sette Savi sulla Vita di Solone di Plutarco", REG 13 (1956) 377-411.

Pordomingo Pardo, Francisca: "El banquete de Plutarco: ¿ficción literaria o realidad histórica?", in Plutarco, Dioniso y el Vino, eds. J. G. Montes Cala, M. Sánchez Ortiz de Landaluce, R. J. Gallé Cejudo (Madrid, 1999), 379-392. 
Rodríguez Adrados, Francisco: "Géneros helenísticos en el Banquete de los Siete Sabios de Plutarco", in Estudios sobre Plutarco: aspectos formales, eds. J. A. Fernández Delgado \& F. Pordomingo Pardo (Salamanca, 1996), 125-142.

Santoni, Anna: "Temi e motivi di interesse socio-economico nella leggenda dei 'Sette Sapienti”, ASNP 13 (1983) 91-160.

Schmidt, Thomas S.: Plutarque et les Barbares. La rhétorique d'une image (Louvain, 1999).

SNell, Bruno: Leben und Meinungen der Sieben Weisen (München, 1952).

Stadter, Philip A.: "Drinking, Table Talk, and Plutarch's contemporaries”, in Plutarco, Dioniso y el Vino, eds. J. G. Montes Cala, M. Sánchez Ortiz de Landaluce, R. J. Gallé Cejudo (Madrid, 1999), 481-490.

Wehrl, Fritz: “Gnome, Anekdote und Biographie”, $M H$ 30 (1973) 193-208.

West, M. L.: The East Face of Helicon. West Asiatic Elements in Greek Poetry and Myth (Oxford, 1997). 
O Banquete dos Sete Sábios 


\section{Nota Prévia}

Para a tradução, usa-se a edição crítica estabelecida por W. R. Paton, Plutarchi Moralia I (Leipzig, Teubner, 1974), 300-338 e (addenda et corrigenda) 399-406. 
1. - Não há dúvida, Nicarco, ${ }^{1}$ de que o tempo ${ }^{\text {I } 46 \text { в }}$ futuro irá lançar muitas trevas e uma completa obscuridade sobre os acontecimentos, se mesmo agora, para factos próximos e ainda frescos, se inventam falsos relatos que ainda assim granjeiam crédito. Com efeito e C para começar, não foram apenas os Sete que se reuniram em banquete (conforme vos terão contado), mas sim mais do que o dobro dessas pessoas - comigo incluído, já que sou íntimo de Periandro, em virtude do meu mester, e era também anfitriáo de Tales, pois este sábio estanciava então em minha casa, seguindo instruçóes de Periandro. ${ }^{2}$ Por outro lado, a pessoa que vos relatou as

${ }^{1}$ Díocles, um velho adivinho frequentador do palácio de Periandro (tirano de Corinto c. 625-585 a.C.), é a pessoa responsável pelo relato (cf. 149d-e; 150b; 151f; 155c; 162c). No exercício dessa função, dirige-se a Nicarco e a outras personagens mais jovens do que o narrador, cuja intervenção se esgota precisamente no papel de ouvintes. Díocles é conhecido apenas deste opúsculo.

${ }^{2}$ A religiosidade de Díocles e o racionalismo de Tales irão confrontar-se ao longo do banquete (cf. infra 149d). Os convidados presentes no banquete são quinze: os Sete Sábios (Tales, Bias, Pítaco, Sólon, Quílon, Cleobulo e Anacársis) e ainda Díocles, Cleodoro, Esopo, Nilóxeno, Árdalo, Mnesífilo, Quérsias e Cleobulina 
conversas não o fez com exactidão, pois, ao que parece, náo terá sequer participado no encontro em questáo. Em todo o caso, já que temos bastante vagar e a minha idade avançada também não dá grandes garantias de que possa adiar mais o relato, vou contar-vos tudo desde o início, aproveitando o vosso desejo de ouvir.

2. Ora Periandro havia organizado a recepção não D na cidade, mas antes na sala de banquetes do Lequeu, junto ao templo de Afrodite, em cuja honra se tinha feito um sacrifício. ${ }^{3}$ Com efeito, depois da sua relação incestuosa com a própria máe, que a levou ao suicídio voluntário, ele não havia dedicado mais sacrifícios a Afrodite, sendo agora a primeira vez que, na sequência de uns sonhos tidos por Melissa, Periandro se decidira a honrar e a venerar a deusa. ${ }^{4}$

Fora posto à disposição de cada um dos convidados um carro puxado por uma parelha de cavalos, devidamente equipado. Com efeito, estávamos em pleno verão e a poeira e o tumulto ocupavam toda a estrada até ao mar, devido à enorme afluência de viaturas

(Eumétis). A este número há que acrescentar ainda Alexidemo, que aparece no início e se afasta antes de o convívio começar, e os anfitrióes, Periandro e a esposa Melissa, bem como Gorgo, irmão do tirano, que faz uma entrada intempestiva, já na parte final do banquete, para narrar a história de Aríon.

${ }^{3} \mathrm{O}$ Lequeu era um dos portos de Corinto, sendo também um dos mais importantes da Grécia. A existência do templo de Afrodite, agora referido, não é confirmada por outras fontes.

${ }^{4}$ A relação incestuosa de Periandro com sua mãe é atribuída por Diógenes Laércio (1.96) ao relato libertino de Aristipo. Parténio (Paixóes de amor, 17) apresenta uma versão de carácter mais romanesco, que estabelece bastantes pontos de contacto com o Conto de Amor e Psique, de Apuleio. 
e de pessoas. Tales, porém, ao ver a carruagem ao pé da entrada, esboçou um sorriso e mandou-a embora. Pusemo-nos então a caminhar tranquilamente, através dos campos, depois de nos termos desviado da estrada principal.

Havia-se juntado a nós um terceiro elemento, $\mathrm{Ni}$ $\mathrm{E}$ lóxeno de Náucratis, pessoa de carácter afável que fizera amizade com Sólon e Tales, no Egipto. ${ }^{5}$ Acontecia ser esta a segunda vez que Nilóxeno era enviado ao encontro de Bias, por razóes que ele mesmo desconhecia, embora suspeitasse que tivessem que ver com um segundo problema que lhe vinha apresentar, em carta selada. Com efeito, recebera instruçóes para, no caso de Bias se negar a responder, mostrar a carta aos mais sábios entre os Helenos.

- É para mim uma grande sorte — comentou Nilóxeno - encontrar-vos todos aqui reunidos e, como podes ver, até levo comigo a carta para o banquete.

Ao mesmo tempo, ia-nos mostrando a missiva, mas Tales retorquiu-lhe, entre sorrisos:

- Se alguma coisa não bate certo, corre de novo até Priene! ${ }^{6}$ Bias encontrará, certamente, uma solução

${ }^{5}$ Nilóxeno é conhecido apenas por esta ocorrência, embora a cidade de onde seria originário, Náucratis, seja uma famosa colónia grega, fundada na parte ocidental do Delta do Nilo. Embora esta fundação remonte à Época Arcaica, há estudiosos que vêem a sua referência neste contexto como um dos anacronismos de Plutarco ao conceber a reunião do grupo de Sapientes, que é de resto em si mesma uma irrealidade histórica.

${ }^{6} \mathrm{O}$ comentário possui uma ressonância proverbial. Quer Tales dizer que, quando havia dificuldades, se ia até Priene, de onde Bias era natural, para encontrar uma solução. 
para esse problema, da mesma forma que a encontrou já da primeira vez.

- Mas qual era então a primeira questão? - inquiri eu.

— O faraó enviou a Bias uma vítima sacrificial esclareceu Tales - com instruçóes para ele separar e enviar -lhe de volta a pior e a melhor parte da carne. Ora o nosso amigo encontrou uma engenhosa e inteligente solução para o problema, ao remeter-lhe a língua que havia cortado. Daqui provém, evidentemente, a fama e respeito de que goza.

Não é só por tal motivo, - acrescentou Nilóxeno - mas também porque, ao contrário de vós, ele náo receia privar com monarcas e de ser conhecido por isso mesmo. ${ }^{7}$ Aliás, também tu forneces muitos motivos para despertar a admiração do meu mestre, embora ele ${ }^{8}$ aprecie em especial a forma como conseguiste medir a pirâmide. De facto, sem grandes canseiras e sem recorrer a qualquer instrumento, colocaste apenas o bastáo em pé no limite da sombra projectada pela pirâmide, de forma a desenhar dois triângulos com a tangente de um mesmo raio de sol, conseguindo assim demonstrar que a pirâmide estabelecia com o bastão a mesma relação que a sombra da primeira estabelecia com a sombra

${ }^{7}$ Esta afirmação constitui o primeiro assomo do imaginário político ligado à figura dos Sete Sábios, que tendiam a ser apresentados como desfavoráveis à tirania. Ora há uma evidente dificuldade em articular essa tradiçáo com o facto de o próprio anfitrião dos Sábios ser tirano de Corinto. Sobre essa questáo, vide supra Introdução, secção 5 .

${ }^{8} \mathrm{O}$ sujeito da frase não se encontra identificado, mas Nilóxeno deve estar a referir-se provavelmente ao faraó Âmasis, que reinou no Egipto entre 570 e 526 a.C. 
do segundo. ${ }^{9}$ Em todo o caso e como antes disse, foste acusado de náo gostares dos reis e chegaram mesmo aos ouvidos do meu senhor certos comentários teus insolentes, a respeito dos tiranos. Com efeito, quando

Molpágoras da Iónia te perguntou qual era a coisa mais incrível que já tivesses visto, deste-lhe a seguinte resposta: «Um tirano que chegasse a velho!» ${ }^{10}$ Noutra ocasiáo, durante um banquete, quando a conversa derivou para os animais, afirmaste que $" \mathrm{O}$ tirano era a pior dos animais selvagens, enquanto o adulador o era

${ }^{9}$ Tales parece ter delineado dois triângulos rectângulos: os catetos do mais amplo eram constituídos pela altura da pirâmide e pelo comprimento da respectiva sombra, medido desde a sua extremidade até ao centro da base da pirâmide; os catetos do triângulo mais pequeno correspondiam à altura do bastão e ao comprimento da sombra que projectava no solo. $\mathrm{O}$ bastão foi colocado no interior da sombra da pirâmide, próximo do seu extremo, de maneira a garantir que a sua ponta superior fosse atravessada pelo mesmo raio de sol que tocava o cume da pirâmide, ou, por outras palavras, de maneira a fazer coincidir os extremos das sombras da pirâmide e do bastão. Assim, os dois triângulos rectângulos ficavam com ângulo agudo inferior comum, tornando-se triângulos semelhantes, caso em que a proporçáo entre os comprimentos dos seus catetos homólogos é igual, permitindo assim calcular facilmente a altura da pirâmide. Segundo Plínio-o-Antigo (História Natural, 36.17) e Jerónimo (apud Diógenes Laércio, 1.27), Tales havia usado uma outra metodologia, que tinha consistido em medir a sombra da pirâmide no momento em que a sombra das pessoas é igual à respectiva altura (quando o sol se encontra a $45^{\circ}$ sobre o horizonte): desta forma, também a altura da pirâmide seria igual ao comprimento da sua sombra. Agradeço ao colega Jorge André, da Faculdade de Ciências e Tecnologia da Universidade de Coimbra, os esclarecimentos dados em relação a esta matéria, que ele próprio expôs, de maneira esquemática, no anexo facultado no termo do livro.

${ }^{10}$ Molpágoras da Iónia esteve activo na segunda metade do séc. VI a.C. Segundo Heródoto (5.30), o seu filho, Aristágoras, foi nomeado governador de Mileto pelo tirano Histieu. 
entre os animais domésticos!». ${ }^{11}$ Ora se bem que os reis pretendam ser muito diferentes dos tiranos, o certo é que não ouvem tais comentários de bom grado.

— Na realidade, — esclareceu Tales — esta observação até foi feita por Pítaco a Mírsilo, certa ocasião, em tom de brincadeira. ${ }^{12}$ Eu disse é que "Ficaria espantado se visse não um tirano, mas antes um comandante de c barco que chegasse a velho.». Quanto a esta mudança de termos, aconteceu-me como àquele rapaz que pretendia bater no cáo e bateu na madrasta, fazendo depois o seguinte comentário: "Também não está mal assim!». Por isso mesmo, Sólon sempre me pareceu particularmente sábio, ao não aceitar tornar-se tirano. E Pítaco, se não tivesse passado pela experiência da monarquia, também não teria dito que "É difícil ser uma pessoa de bem.». Já Periandro, segundo parece, embora tenha chegado a tirano como quem apanha uma doença hereditária, não se está a sair mal, graças às salutares companhias, ao menos até agora, e ao convívio com pessoas de bom senso, que atrai para junto de si, em lugar de seguir as indicaçóes que lhe dá o meu concidadão Trasibulo, de que D deve «cortar as pontas mais altas». ${ }^{13} \mathrm{Na}$ realidade, não

${ }^{11}$ Noutro ponto da sua obra (Como distinguir um adulador $e$ um amigo, 19, 61c), Plutarco atribui esta mesma sentença a Bias, com o comentário de que a categoria dos aduladores exemplifica, por si só, o que há de pior entre animais selvagens e domésticos.

${ }^{12}$ Tanto Pítaco de Mitilene como Mírsilo foram importantes figuras políticas da ilha de Lesbos, em especial na viragem do séc. VII a.C. Ambos conheceram a inimizade do poeta Alceu, representante da resistência aristocrática, a quem Mírsilo mandou para o exílio.

${ }^{13}$ A expressão "cortar as pontas mais altas" aplica-se, em contexto político, ao carácter anti-aristocrático das tiranias, de que 
existe nenhuma diferença entre o lavrador que prefere colher joio e passarada em lugar de trigo e cevada, e um tirano que deseja governar sobre escravos em vez de o fazer sobre homens livres. De facto, como contrapartida por tantos incómodos, o exercício do poder apresenta uma vantagem somente, que é a honra e a fama, no caso de os chefes governarem sobre homens excelentes sendo melhores do que eles, gozando ainda a reputação de ultrapassarem a grandeza de súbditos igualmente valorosos. Porém, os que apreciam a segurança sem curarem do prestígio deveriam era comandar manadas de carneiros, cavalos e bois, mas não homens.

- Mas já basta deste assunto, - continuou o mesmo Tales - pois este nosso visitante levou a conversa para matérias muito desviadas, e nós assim acabámos por descurar a preocupação de buscar temas ajustados a quem se dirige para um banquete. Ou julgas tu que, tal como há diligências próprias do anfitrião, não há também preparativos que cabem ao convidado? Com efeito, os Sibaritas, segundo parece, enviam os convites às senhoras com a antecedência de um ano, a fim de elas terem tempo para se apresentarem no banquete com os vestidos e as jóias mais convenientes. ${ }^{14}$ Ora quanto

resultou frequentemente um maior nivelamento social. Segundo Heródoto (5.92.6), Trasibulo (tirano de Mileto em finais do séc. VII a.C.) teria dado este conselho a Periandro, através do gesto de cortar as espigas que se sobrelevavam. Na sequência desse alvitre, Periandro endureceu o governo, tornando-se mais cruel do que fora seu pai, Cípselo. Porém, segundo Aristóteles (Política, 3.1284a) teria sido Periandro a fazer essa sugestão a Trasibulo e não o contrário.

${ }^{14}$ Síbaris era uma rica cidade da Magna Grécia, famosa pelo 
a mim, a verdadeira preparaçáo para quem deseja participar num banquete como deve ser exige muito mais tempo, pois é bem mais difícil encontrar o ornamento adequado ao espírito, do que um adorno supérfluo e inútil para o corpo. $\mathrm{Na}$ verdade, quem possui discernimento náo vai para um banquete levando-se a si mesmo como se fora um vaso para encher, mas antes para conversar a sério e a brincar, para ouvir e para falar de acordo com o que a ocasião sugerir aos participantes, se a companhia de uns e de outros se F revelar agradável. ${ }^{15}$ Com efeito, se um prato é mau, podemos recusá-lo, e se o vinho é fraco, podemos recorrer à água da fonte. No entanto, se um conviva provoca dores de cabeça, se é insuportável e grosseiro, nesse caso destrói e estraga o prazer de qualquer bebida e comida, ou mesmo de qualquer músico. Além disso, não há maneira de conseguir

I 48A vomitar a causa de tamanha repugnância. Com efeito, no caso de algumas pessoas a sua antipatia para com os outros mantém-se pela vida fora, como um amargo de boca, decorrente da insolência ou da cólera provocada pelo vinho. Por isso, Quílon ${ }^{16}$ agiu muito bem, pois embora fosse convidado ontem, não confirmou a presença antes de conhecer o nome de cada um dos comensais. Comentava ele, com efeito, que é preciso aguentar a ignorância de um companheiro de cabine ou de tenda, durante uma viagem ou campanha militar, mas ir misturar-se ao acaso com companheiros de

carácter refinado e faustoso da sua vida social.

15 Esta ideia vem expressa também na obra No banquete, 660b.

${ }^{16}$ Quílon de Esparta (éforo em 556/555 a.C.), além de integrar a lista usual dos sábios, é considerado, tal como Sólon, um dos políticos mais influentes do seu tempo. A tradicional constituição espartana deve ser, em boa parte, fruto da sua actividade legislativa. 
banquete não é coisa própria de quem tenha bom senso. Os Egípcios cultivam o acertado costume de levar para os banquetes um esqueleto, que mostram depois aos convivas, exortando-os a lembrar-se de que em breve seráo como ele. E se bem que a presença deste comensal seja incómoda e pouco adaptada à circunstância, tem ainda assim alguma utilidade, pois não os incita à bebida e à folgança, mas antes à amizade e ao mútuo afecto, dissuadindo-os de se desgastarem muito em grandes contendas, quando é tão curta a duração desta vida. ${ }^{17}$

3. E no meio destas conversas, lá fizemos o caminho, até chegarmos diante da casa. Tales não estava interessado em tomar banho, pois já nos tínhamos ungido com óleo. E assim, foi antes percorrer e inspeccionar as pistas de corrida, as salas de treino e o bosque junto do mar, primorosamente cuidado. Procedia assim não porque se deixasse impressionar grandemente por qualquer destas coisas, mas para não dar a entender que desdenhava, com altivez, da munificência de Periandro. Quanto aos restantes convidados, à medida que se houvessem ungido com óleo ou lavado, iam sendo conduzidos pelos servos até à sala de jantar, ${ }^{18}$ através do pórtico. Anacársis ${ }^{19}$ estava sentado sob esse mesmo pórtico e à

${ }^{17}$ Já Heródoto (2.78) referia este macabro costume dos Egípcios. Petrónio (Satyricon, 34) faculta uma caricatura desta mesma prática no famoso banquete de Trimalquiáo.

${ }^{18} \mathrm{O}$ termo grego (ả $\left.\delta \delta \rho \omega ́ v\right)$ significa, à letra, 'sala dos homens'. Sobre o significado que pode assumir a presença de mulheres no espaço do banquete, vide supra Introdução, secção 4 .

${ }^{19}$ Anacársis era um príncipe da Cítia, de ascendência real, que viveu no séc. VI a.C., altura em que terá viajado por toda a Grécia. $\mathrm{Na}$ sequência dessas viagens, ganhou fama de pessoa ponderada, 
sua frente encontrava-se uma menina em pé, que lhe penteava a cabeleira com as mãos. Entretanto, a jovem correu para junto de Tales, com muita familiaridade. Este beijou-a e comentou, a sorrir:

- Vai lá e trata de alindar este visitante estrangeiro, para que o seu aspecto náo nos infunda receio nem tenha um ar tão selvagem, quando ele é, na verdade, uma pessoa bem civilizada.

Quando procurei inteirar-me sobre a identidade daquela menina, ele retorquiu:

- Pois então não conheces a sábia e famosa Eumétis? É esta a alcunha que lhe dá o pai, já que a maioria das pessoas a conhece antes pelo nome de Cleobulina, que lhe vem do lado paterno. ${ }^{20}$

- Imagino que estejas a louvar as capacidades desta rapariga — atalhou Nilóxeno — em atenção à habilidade e agudeza dos seus enigmas. Com efeito, algumas das adivinhas de sua autoria chegaram mesmo até ao Egipto.

— De forma alguma! — respondeu Tales — Os

sendo apresentado pelas fontes ora como um mártir da cultura grega ora ainda como uma espécie de "bom selvagem", impoluto e, por isso mesmo, capaz de denunciar os vícios da civilização. Vide supra Introdução, secção 5 .

${ }^{20}$ Cleobulina era filha de Cleobulo, tirano de Lindos. Há uma comédia de Cratino intitulada Cleobulinas (cf. Diógenes Laércio, 1.89), pelo que já tem sido aventada a hipótese de que este nome seja a personificação dos enigmas inventados por Cleobulo. A alcunha Eumétis é igualmente um nome falante, pois significa 'prudente', 'avisada'. Sobre a influência positiva que esta presença feminina discreta exerce no ambiente masculino do banquete (em especial sobre o pai, a quem torna mais 'afável' e mais 'democrático', moderando assim o facto de ser um tirano), vide supra Introdução, secção 6 . 
enigmas são apenas uma espécie de jogo de dados, ${ }^{21}$ de que ela se serve para brincar em determinado momento e que lança aos companheiros de ocasiáo. $\mathrm{Na}$ verdade, ela possui uma inteligência notável, uma apurada sensibilidade política e um carácter generoso, que faz de seu pai um governante mais afável para com os concidadáos e mais democrático.

- Certo - retorquiu Nilóxeno - e isso torna-se evidente para quem reparar na sua simplicidade e desafectação. Mas por que motivo dispensa ela tão carinhosos cuidados a Anacársis?

- Porque é um homem ponderado e muito sabedor. - explicou Tales - Para mais, também lhe en-

sinou generosamente e de bom grado a dieta alimentar e as purificaçóes a que os Citas recorrem para tratar as maleitas. ${ }^{22}$ Imagino aliás que, no preciso momento em que o rodeia com estes cuidados, ela estará a aprofundar os conhecimentos ao dialogar com Anacársis.

Já nos encontrávamos próximo da sala de jantar, quando veio ao nosso encontro Alexidemo de Mileto (um filho ilegítimo do tirano Trasibulo). ${ }^{23}$ Estava de saída

${ }^{21}$ À letra 'ossinhos', pois era com pequenos ossos que se jogava, se bem que o efeito obtido acabasse por ser semelhante aos dados.

${ }^{22}$ Apenas neste opúsculo se refere o conhecimento que Anacársis teria das purificaçôes a aplicar aos enfermos. Mais adiante (infra 158a), Anacársis comenta as qualidades higiénicas da malva e do asfódelo, o que vai ao encontro do interesse que teria por dietas salutares.

${ }^{23}$ Sobre Alexidemo de Mileto sabe-se apenas o que é dito neste passo. Tem sido colocada a hipótese de ser uma personagem inventada, extensão do tirano Trasibulo, já que o seu nome pode significar algo como 'o que mantém o povo à distância'. Sendo, como Tales, originário de Mileto, serve também para estabelecer com o 
e com ar agitado, ao mesmo tempo que falava em tom colérico consigo mesmo, sem que nós percebêssemos nada do que dizia. Assim que deu pela presença de Tales, conteve um pouco o ânimo, estacou e disse:

- Que afronta acaba de nos fazer Periandro! Não F me deixou embarcar como era minha intenção, mas antes instou comigo a que ficasse para jantar. Porém, quando compareci no banquete, atribuiu-me um posto indigno, dando preferência a Eólios e a insulares (ou seja, a toda a gente) sobre Trasibulo. Com efeito, é bem evidente que ele quis enxovalhar e desprezar em mim a pessoa que me enviou — portanto Trasibulo — a fim de mostrar que não tem respeito por dele.

— E então, — replicou Tales — recearás tu por-

I49A ventura a sorte atribuída pelos Egípcios aos astros, que segundo eles se tornam melhores ou piores do que eram antes, de acordo com a posição mais elevada ou mais baixa que ocupam nas regióes celestes que estejam a atravessar? Julgarás que também contigo se registará um obscurecimento ou abaixamento só por causa de um posto? E serás tu inferior àquele espartano que, tendo sido relegado pelo responsável para a última posiçáo num coro, comentou: «Encontraste uma bela maneira de dignificar também este lugar!»?24 Quando nos é designado um posto — continuou Tales — não interessa tentar saber quem foi colocado antes de nós, mas antes

sapiente um nítido contraste.

${ }^{24}$ A ideia é que cabe à pessoa dignificar o posto que ocupa e não o contrário. Noutros pontos da sua obra, Plutarco atribui um comentário desta natureza ora a Agesilau (Sentenças dos Lacedemónios, 208d) ora a Damónidas (ib., 219e). 
procurar a melhor forma de nos tornarmos agradáveis aos nossos vizinhos, a fim de neles mesmos buscarmos de imediato um ponto de partida e de apoio para a amizade. Aliás, logo o encontraremos, pois em vez de permanecermos de mau humor, ficaremos satisfeitos por estarmos na companhia daquelas pessoas. $\mathrm{Na}$ verdade, quem desconsidera o lugar que ocupa à mesa, desconsidera mais o comensal seu vizinho do que a pessoa que o convidou, tornando-se odioso a ambos.

- Esses comentários não passam de palavras, de simples palavras! - contrapôs Alexidemo - Eu bem vejo que vós, os sábios, também procurais com todo o empenho alcançar honrarias!

E com isto passou a nosso lado e foi-se embora. Tales virou-se então para nós, que estávamos atónitos ainda com a extravagância do sujeito, e explicou:

- Estes excessos e este desvario estão na sua natureza. De facto, era ele ainda um rapazinho quando ofereceram a Trasibulo um perfume precioso; ora ele deitou-o num grande vaso para refrescar a bebida, juntou-lhe vinho puro e bebeu-o tudo, atraindo sobre si o ódio de Trasibulo, em vez da amizade. ${ }^{25}$

Depois deste episódio, veio ao nosso encontro um C servo com as seguintes instruçóes:

- Periandro pede-te que venhas, na companhia de Tales, que também aqui se encontra presente, examinar o que lhe trouxeram mesmo agora, para ver se é uma

${ }^{25}$ A actuação de Alexidemo constitui uma dupla provocação, pois ao desperdício do perfume há que acrescentar o acto de beber vinho puro, que entre os Gregos era considerado uma atitude própria do descontrolo bárbaro. 
coisa sem importância ou se, pelo contrário, se trata de um sinal ou presságio. Em todo o caso, ele parece ter ficado bastante perturbado, por achar que talvez seja uma forma de contaminação que pode manchar o sacrifício.

Entretanto, o servo conduziu-nos até um dos aposentos dispostos em redor do jardim. No interior, um rapazito com aparência de pastor, ainda imberbe e de ar nada desagradável, desdobrou um manto de couro e mostrou-nos uma criatura recém-nascida, que fora parida por uma égua, segundo ele. Tinha aspecto humano na parte de cima do corpo, até à altura do pescoço e dos D braços; na parte restante, possuía forma equina e a voz assemelhava-se aos vagidos de uma criança acabada de nascer.

- Deus nos guarde! ${ }^{16}$ - Exclamou logo Nilóxeno, ao mesmo tempo que desviava o olhar.

Tales, porém, demorou-se bastante tempo a contemplar o recém-nascido. Abriu finalmente um sorriso em minha direcção, pois costumava brincar sempre comigo por causa da minha arte, e disse:

- Certamente, Díocles, já pensas iniciar as purificaçóes e dar trabalho às divindades apotropaicas, como se tivesse acontecido algum mal pavoroso e extraordinário.

— E porque não? — respondi eu — Em boa verdade, Tales, estamos perante um sinal de agitação e desentendimento, e receio bem que alastre à esposa e à descendência de Periandro, antes mesmo de ser expiada a primeira

${ }^{26}$ ' $\mathrm{A} \lambda \in \xi$ '́какоs ('o que afasta os males') é um epíteto de várias divindades (Zeus, Apolo e sobretudo de Héracles) e possui, obviamente, um valor apotropaico. 
ofensa que irritou a deusa, dado que ela manifesta a sua cólera pela segunda vez, conforme podes constatar. ${ }^{27}$

Perante estas palavras, Tales nada proferiu, optan- E do antes por afastar-se, a sorrir. ${ }^{28}$

Periandro veio esperar-nos junto da porta, a fim de saber qual era a nossa opiniáo sobre o que tínhamos visto. Tales deixou-me, então, de lado e pegou na mão dele, dizendo:

- Quanto aos conselhos de Díocles, poderás cumpri-los com calma. Pela minha parte, recomendo somente que não ponhas pastores tão jovens a tomar conta de éguas ou então que trates de lhes arranjar mulher.

$\mathrm{Na}$ verdade, a mim pareceu-me que Periandro ficou muito satisfeito ao ouvir estas advertências. Com efeito, não só desatou a rir, como rodeou Tales com os braços e o apertou amistosamente contra si.

- Penso aliás, Díocles, - concluiu Tales - que o presságio até já se cumpriu, pois bem vês a desgraça enorme que nos aconteceu, quando Alexidemo se negou a jantar connosco!

4. Já depois de havermos entrado, Tales elevou a voz para perguntar:

${ }^{27}$ A deusa em questão é Afrodite, aqui evocada por causa da relação incestuosa de Periandro com a própria mãe. Os receios referidos por Díocles acabarâo por confirmar-se, pois Periandro irá matar a esposa Melissa e perderá todos os filhos (tanto legítimos como ilegítimos), a ponto de deixar o trono ao sobrinho, Psamético. Psamético assumirá o nome de Cípselo II, mas será morto escassos três anos depois de subir ao poder, pondo fim à dinastia dos Cipsélidas. Cf. Heródoto, 3.50-53.

${ }^{28}$ Assumindo assim uma posição racionalista, em nítido contraste com os receios supersticiosos de Díocles. 
- Em que lugar iria, afinal, reclinar-se o tal sujeito, para se andar a queixar?

Assim que lhe deram a indicação, dirigiu-se para esse leito e aí se reclinou, convidando-nos a fazer o mesmo. Em seguida, comentou:

- Em boa verdade, eu teria inclusive pago a fim de partilhar com Árdalo a mesma mesa! ${ }^{29}$

Este Árdalo de Trezena era um tocador de flauta e sacerdote das Musas Ardálidas, cujo culto fora instituído por Árdalo-o-Velho, também de Trezena. ${ }^{30}$ Ora acontecia que Creso tinha enviado Esopo, pouco tempo antes, em missáo a Periandro e ao deus de Delfos, de maneira que também ele estava presente no banquete, sentado num pequeno escabelo, junto de Sólon, que se encontrava reclinado num plano superior. ${ }^{31}$ Esopo disse então:

- Havia um mulo da Lídia que, ao ver a própria imagem reflectida nas águas de um rio, ficou espantado com a beleza e imponência do seu corpo, pondo-se a correr a toda a brida e a sacudir a crina, como se fosse um cavalo. Depois, ao tomar consciência de que era

${ }^{29}$ Os convivas ficavam reclinados em leitos, mas à sua frente eram depois colocadas pequenas mesas com os alimentos.

${ }^{30}$ Este Árdalo-o-Velho seria filho de Hefestos e, além deste santuário, era-lhe atribuída também a invenção da flauta (cf. Pausânias, 2.31.3; Pseudo-Plutarco, Sobre a Música, 1133a). O Árdalo que agora participa no banquete mostrará um pouco mais adiante (infra 150d) um interesse particular por flautas, ao conversar com Anacársis, um pormenor aliás facilmente explicável pelo facto de ser flautista.

${ }^{31}$ Esta diferença de planos acentua, no espaço do banquete, a diferente origem dos dois homens: Sólon tinha origem aristocrática, enquanto Esopo era um antigo escravo. 
filho de um burro, estacou a pressurosa correria e abandonou o orgulho e o entusiasmo.

Nesse momento, Quílon fez o seguinte comentário, à maneira lacónica:

- Também tu és lento, mas andas com as correrias do mulo! ${ }^{32}$

Nesse instante, entrou Melissa, que se reclinou junto de Periandro, enquanto Eumétis se sentou junto $\mathrm{de}^{33}$... a fim de participar no banquete. Tales virou-se então para mim (que estava um lugar acima de Bias) e perguntou:

${ }^{32}$ Passo de interpretação controversa, reforçando assim (e talvez propositadamente) o "laconismo" da personagem. Tem sido aventada a hipótese de que a fábula evocada por Esopo visasse atingir a soberba de Alexidemo (que era filho "ilegítimo" de Trasibulo) ou até eventualmente Árdalo, embora esta segunda possibilidade se afigure menos provável. No entanto, o destinatário do remoque de Quílon deve ser o próprio Esopo, pois era um antigo escravo que se movimentava agora em ambientes socialmente elevados. $\mathrm{O}$ comentário do espartano estaria de acordo, aliás, com alguma tensão latente, embora discreta, que existe na relação entre Esopo e o grupo dos sapientes.

${ }^{33}$ Neste ponto, vem assinalada uma lacuna, que alguns filólo-

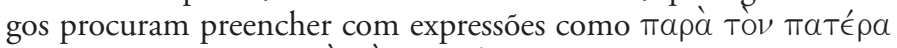

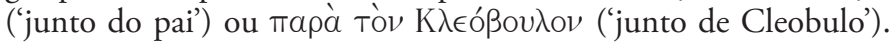
Lo Cascio (1997), 207, sustenta, com certa pertinência, que talvez não falte texto, partindo do princípio de que Eumétis «se sentou junto do lugar onde decorria o banquete», portanto sem tomar propriamente um posto, ao qual não teria direito, pelo facto de ser ainda menina. Ainda assim, afigura-se mais viável a outra hipótese colocada pelo mesmo autor, de que faltaria a expressão tapà aủTńv (scil. Melissa). De resto, a diferença de tratamento de Cleobulina/ Eumétis já era visível no facto de ficar sentada (como Esopo), enquanto os restantes se reclinavam. Sobre a relaçáo simbólica que estas duas personagens podem estabelecer no espaço do banquete, vide supra Introdução, secção 6 . 
- Díocles, porque não preveniste Bias de que o estrangeiro de Náucratis veio novamente à procura dele com problemas suscitados pelo faraó, de maneira a que ele se mantenha sóbrio e concentrado, até receber a mensagem?

- Há um bom tempo já — retorquiu Bias — que este sujeito me tenta infundir receio com este tipo de advertências. Mas eu bem sei que Diónisos, além de possuir muitos outros talentos, é também conheciC do por Libertador ${ }^{34}$ devido à sua sabedoria, de maneira que, ficando eu bem atestado com a influência do deus, náo tenho receio de ir à luta com menos coragem.

E assim entravam uns com os outros, ao longo do banquete. Quanto a mim, ao ver que o jantar era mais frugal do que geralmente acontecia, veio-me ao pensamento que receber e convidar pessoas sábias e bem formadas não faz aumentar os gastos, mas pelo contrário, até os diminui. E isto porque dispensa os excessos de iguarias, os perfumes exóticos, os bolos e a profusão de vinhos muito caros, recursos estes que Periandro usava no dia-a-dia, de acordo com a riqueza e o poder próprios de um tirano. Nesta ocasião, porém, procurava impressionar os convidados com a simplicidade e a moderação nos gastos.

D E não agiu assim apenas em relação a estes aspectos, pois também à mulher fez retirar ou ocultar os ornamentos habituais, apresentando-a com modéstia e recato.

5. Depois de se terem levantado as mesas e de Melissa haver distribuído as coroas, nós fizemos várias

${ }^{34} \Lambda$ ú เos significa à letra 'o que deslaça' 'o que liberta de peias'; daí que, por extensão, possa designar também 'o que resolve problemas'. 
libações, que a flautista sublinhou com um breve acompanhamento musical, afastando-se logo a seguir. Árdalo voltou-se, então, para Anacársis e perguntou-lhe se entre os Citas havia flautistas.

— Não, nem tão pouco vinhas. - Retorquiu ele, de improviso.

— Mas há na Cítia deuses, ao menos? — Insistiu novamente Árdalo.

- Pois com certeza — respondeu Anacársis — e conseguem entender a linguagem humana. Os Helenos, pelo contrário, embora tenham a presunção de falar melhor do que os Citas, acreditam que aos deuses agrada mais ouvir sons retirados de ossos e pedaços de madeira.

— E se tu soubesses, estrangeiro, — atalhou Esopo - que os actuais fabricantes de flauta puseram de lado os ossos de veado, para usarem antes os de asno, pois acham que tem melhor sonoridade! É por isso que Cleobulina inventou a seguinte adivinha a propósito da flauta frígia:

Um burro morto, com a canela revestida de corno, nas orelhas me bateu!

É pois coisa de espantar que, sendo o burro tão grosseiro e contrário aos dons das Musas, consiga fornecer um osso táo fino e apto para a música.

- É essa a justificação seguramente — comentou Nilóxeno - para o facto de as gentes de $\mathrm{Bu}-{ }_{\mathrm{F}}$ síris andarem a reclamar contra nós, habitantes de 
Náucratis: com efeito, nós já usamos ossos de burro no fabrico de flautas. ${ }^{35} \mathrm{Na}$ óptica deles, de resto, o simples facto de se escutar uma trompeta constitui desde logo um sacrilégio, precisamente por ter uma ressonância semelhante à do burro. Vós sabeis, pela certa, que o burro é desprezado pelos Egípcios, precisamente devido a Tífon.

6. Entretanto fez-se silêncio e Periandro, ao ver que Nilóxeno desejava tomar a palavra mas ainda hesitava, declarou:

- Meus caros senhores, eu louvo as cidades e os governantes que, nas audiências, dão prioridade aos estrangeiros sobre os próprios cidadãos. E agora, sou de opinião que suspendamos durante algum tempo os nossos assuntos, pois dizem respeito a coisas da terra e habituais, para darmos lugar, como acontece na assembleia, às matérias egípcias e reais, que o bom do Nilóxeno veio expor a Bias e que Bias gostaria de ponderar na presença de todos nós.

- Com efeito, em que lugar e na companhia de quem — sublinhou Bias — iria uma pessoa assumir de boa mente o risco, em caso de necessidade, de avançar com respostas destas, em especial quando o próprio rei

${ }^{35}$ Busíris era uma pequena cidade do Baixo Egipto, situada no Delta do Nilo. No tratado que constitui a melhor fonte antiga para o conhecimento da luta entre Osíris e Tífon/Seth (Sobre Isis e Osiris, 362f), Plutarco regista que os habitantes de Busíris e de Licópolis não usam trompetas de nenhum tipo, exactamente por o som produzido se assemelhar ao do burro, como adiante se reforça também. Em $O$ burro de ouro de Apuleio, a luta simbólica entre o bem (representado pela acção de Ísis e Osíris) e o mal (simbolizado na imagem asinina) constitui uma importante chave interpretativa da obra. 
deu instruçốes para se começar por mim e passar em seguida a palavra a todos vós?

$\mathrm{Na}$ sequência desta intervenção, Nilóxeno в passou-lhe a missiva, mas Bias insistiu com ele para que a abrisse e lesse em voz alta, na presença de todos. $\mathrm{O}$ teor da carta era o seguinte:

Âmasis, rei dos Egípcios,

a Bias, o mais sábio de todos os Helenos:

O rei dos Etíopes está a disputar comigo um concurso de sabedoria. Depois de haver sido batido em todas as restantes provas, desafiou-me agora para uma tarefa absurda e temerosa: instou-me a beber a água do mar até à última gota. Se eu conseguir resolver esta dificuldade, recebo dele muitas vilas e cidades, mas se não conseguir terei entáo de me desfazer de Elefantine ${ }^{36} \mathrm{e}$ das povoaçôes em redor. Examina, por conseguinte, o problema e envia de imediato Nilóxeno com a resposta. E se os teus amigos ou concidadáos precisarem de alguma coisa da nossa parte, não encontrarão qualquer impedimento.

Depois da leitura da missiva, Bias não esperou muito tempo, antes reflectiu um pouco para consigo mesmo e, depois de trocar algumas impressóes com Cleobulo, que se encontrava reclinado junto de si, comentou:

${ }^{36}$ Elefantine era uma cidade do Alto Egipto, vista geralmente como a fronteira entre o Egipto e a Etiópia. 
- Que dizes tu, habitante de Náucratis? E Âmasis, que reina sobre tantos súbditos e possui um território tão belo e extenso, estará ele disposto a beber toda a água do mar, só por causa de umas vilórias miseráveis e sem importância?

- Parte do princípio de que estará disposto a isso e vê então o que se poderá fazer! - Respondeu Nilóxeno, com uma risada.

— Pois bem, - atalhou Bias — ele que diga ao rei dos Etíopes para estancar todos os rios que desaguam nos oceanos, a fim de ele poder então beber a água que D neste momento há no mar. Com efeito, a tarefa consistia em beber a água que agora existe no mar e não a que venha a existir no futuro!

Assim que Bias proferiu estas palavras, Nilóxeno ficou radiante de alegria, envolveu Bias num abraço e deu-lhe um beijo. Perante o elogio e aprovaçáo geral, Quílon disse, com uma boa gargalhada:

- Caro estrangeiro, antes que o mar desapareça, sorvido até à última gota, embarca e vai contar a Âmasis para não se preocupar em saber de que forma há-de consumir a água dos oceanos, mas que procure antes tornar o seu reinado potável e doce para os súbditos. ${ }^{37} \mathrm{Com}$ efeito, em relação a estas matérias Bias é um verdadeiro especialista e poderá ensinar melhor do que ninguém a forma de Âmasis não precisar de recorrer mais à sua bacia de lavar os pés, feita em ouro, para se impor aos

${ }^{37}$ A metáfora é frequente e deve entender-se por oposição à água salgada que, por isso mesmo, se torna intragável. Vide e.g. Platão, Fedro (243d), que usa esta imagem para referir-se à "potabilidade" de um discurso. 
Egípcios. ${ }^{38}$ Pois se ele se mostrar um soberano virtuoso, todos lhe dispensarão reverência e afeição, mesmo que a sua origem fosse dez mil vezes mais humilde do que a sua presente posição.

— Não há dúvida - acrescentou Periandro — de que valeria a pena que todos contribuíssemos, «homem a homem», conforme diz Homero, para fazer estas ofer$\operatorname{tas}^{39}$ ao Faraó: para ele, este presente extra teria mais valor do que toda a mercadoria e, para nós, seria mais útil do que qualquer outra coisa.

7. Quílon disse então que seria perfeitamente justo que coubesse a Sólon a primazia no uso da palavra, não apenas porque os ultrapassava a todos em idade e ocupava o posto de honra à mesa, mas também devido ao facto de haver exercido o mais elevado e completo governo, ao estabelecer leis para os Atenienses.

Nilóxeno dirigiu-me então o seguinte comentário, em voz baixa:

- Muitas vezes, Díocles, dá-se crédito a coi- F sas que são pura invençáo, e a maior parte das pessoas alinha de bom grado seja a engendrar histórias seja a acolher prontamente rumores postos a circular

${ }^{38}$ Heródoto (2.172) relata que, ao sentir que a sua origem humilde era inicialmente causa de desprezo, Âmasis mandou modelar uma estatueta divina a partir de uma bacia em ouro para lavar os pés. Dado que a ninguém causava incómodo adorar a imagem, revelou a maneira como havia sido feita, de forma a demonstrar que a origem náo é, em si mesma, causa de menor respeito.

${ }^{39}$ Cf. Homero, Odisseia, 13.14. O termo átrapxaí, aqui traduzido por 'ofertas', tem mais o sentido técnico de 'primícias' oferecidas aos deuses e já tem sido interpretado como referindo-se às primícias de sabedoria que os Sapientes teriam oferecido a Apolo, em Delfos. Vide Platáo, Protágoras, 343b. 
por outros com relatos pouco edificantes a propósito dos Sapientes. É o que aconteceu, por exemplo, com o boato que chegou até nós, no Egipto, a respeito de Quílon, segundo o qual ele teria desfeito os laços de I 52A amizade e de hospitalidade com Sólon, apenas porque o ateniense teria afirmado que as leis podiam ser sujeitas a revisão.

— É uma história ridícula, — retorqui — pois a ser verdade Quílon teria de renegar primeiro Licurgo juntamente com as suas leis, pois ele alterou por completo a constituição dos Lacedemónios.

Depois de fazer uma breve pausa, Sólon disse:

— Em minha opinião, será especialmente digno de glória o rei ou tirano que criar, em favor dos cidadãos, uma democracia a partir da monarquia.

- E o que tomar a dianteira a harmonizar a sua actuação com as leis da pátria. - Acrescentou Bias, logo a seguir.

Depois disso, Tales declarou que era feliz o governante que viesse a morrer de velhice e de causas naturais.

— E o que não for o único a mostrar sensatez. Ajuntou Anacársis, em quarto lugar.

- E o que não der confiança a nenhum dos seus colaboradores. - Disse Cleobulo, em quinto.

- E o governante capaz de conseguir que os súbditos tenham náo medo dele, mas antes medo por ele. - Sentenciou Pítaco, em sexto lugar.

Em seguida, Quílon comentou que um governante não deveria nunca pensar como um mortal, mas sempre como um imortal. 
Uma vez proferidas tais sentenças, nós insistimos com Periandro para que também ele desse a sua opinião. A contragosto e com a testa franzida, ele acabou por apresentar esta reflexão:

- Pela minha parte, creio que, se juntarmos todas as sentenças expressas, praticamente impedimos qualquer pessoa de bom senso de vir a tornar-se governante.

- O melhor seria mesmo tecer estas reflexões entre nós mesmos, - disse Esopo, em tom de admoestação - em vez de irmos acusar os governantes, com a C desculpa de sermos seus conselheiros e amigos.

Sólon tocou-lhe então na cabeça, esboçou um sorriso e fez o seguinte comentário:

- Náo te parece que pode tornar mais moderado um governante e mais razoável um tirano a pessoa que o conseguir convencer de que é preferível não governar a estar no governo?

- E quem se iria deixar persuadir pelos teus argumentos - retorquiu ele - e não pelas palavras do deus, quando proferiu, a propósito de ti mesmo, este oráculo:

Feliz a cidade que um só arauto escuta. ${ }^{40}$

- Em boa verdade, — respondeu Sólon — ainda agora os Atenienses escutam um arauto apenas e a

${ }^{40} \mathrm{Na}$ biografia de Sólon, Plutarco não regista este oráculo, se bem que refira um outro, relativo também à forma de usar o poder. Ainda assim, nos seus versos (e.g. frg. 33 WEST), o estadista não deixa de sugerir que um deus havia colocado à sua disposiçáo o poder. Cf. Plutarco, Vida de Sólon, 14. 
um só governante, a lei, já que possuem a democracia. Tu és muito hábil a perceber os corvos e os gaios, mas não consegues entender correctamente a voz do deus: D por um lado, achas que, de acordo com o deus, uma cidade goza de grande prosperidade quando obedece a um só governante, ao mesmo tempo que vês a excelência de um banquete no facto de todos poderem falar sobre todos os assuntos.

- Certo, — concedeu Esopo — mas isso é porque tu náo escreveste ainda uma lei que proíba, em Atenas, os escravos de se embebedarem, análoga à que promulgaste para os impedir de se envolverem amorosamente e de se ungirem com óleo. ${ }^{41}$

Sólon esboçou então um sorriso e o médico Cleodoro comentou:

- Mas ungir-se com óleo é como cavaquear quando se está bem encharcado em vinho: constitui um grande prazer!

- Ora aí está mais uma razáo para se absterem dessas práticas! — Interpôs Quílon, depois de tomar a palavra.

${ }^{41}$ Para frequentarem o ginásio. Esta lei vem referida, com ligeiras variantes, em Ésquines (1.138-139) e igualmente em Plutarco, Vida de Sólon, 1.6. A proibição de os servos frequentarem o ginásio pode entender-se como norma de natureza social, uma vez que estes lugares eram usados, sobretudo, por quem dispunha de tempo e dinheiro suficientes para náo se ver obrigado a trabalhar. Sendo uma ocupação ligada, em especial, ao estilo de vida dos aristocratas, não pareceria bem ao legislador que os escravos também dela pudessem usufruir. No mesmo sentido se compreende a interdiçáo de os servos privarem em demasia com jovens de situaçáo livre, pois o contrário seria desprestigiante para estes últimos e poderia traduzir-se num acto de hybris em relação à dignidade própria do seu estatuto, enquanto futuro cidadáo de plenos direitos. Notar que Esopo é um ex-escravo. 
- Ainda assim, - insistiu novamente Esopo parece-me que Tales havia comentado que $<^{* * *}>$ tu estás a ir para velho a passos largos. ${ }^{42}$

8. Periandro começou também a rir e disse:

- Estamos a ser punidos com toda a justiça, Esopo, pois deixámo-nos levar para outros assuntos antes de ponderarmos todas as questóes de Âmasis, às quais havíamos dado precedência. Por isso, Nilóxeno, expóe o teor do resto da carta, aproveitando a presença aqui destas personalidades.

— Em boa verdade, - retorquiu Nilóxeno - a disposição do rei dos Etíopes mais não constitui do que uma «lamentável mensagem secreta», como dizia Arquíloco. ${ }^{43}$ Porém, o teu hóspede Âmasis mostrou-se bem mais civilizado e instruído nos problemas que coloca à vossa consideração: com efeito, ele pediu para lhe dizerem qual era a coisa mais velha, a mais bela, a mais extensa, a mais sábia, a mais comum e, além de tudo isto, por Zeus, a mais útil, a mais prejudicial, a mais forte e a mais fácil. ${ }^{44}$

42 Neste ponto, o texto deve apresentar provavelmente uma lacuna, já que o sentido do comentário é difícil de entender. Entre as várias hipóteses que têm sido aventadas, talvez a mais satisfatória seja a de que Esopo justifica a austeridade de Quílon com a idade avançada e, portanto, com a dificuldade de apreciar já os prazeres em causa.

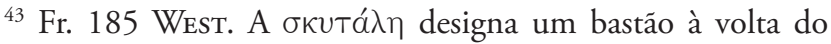
qual se enrolava uma mensagem escrita, que só poderia ser decifrada por quem possuísse um bastão idêntico. Era um mecanismo usado pelos Espartanos, sobretudo para garantir o carácter secreto de mensagens de cariz militar, por norma concisas. Na Vida de Lisandro (19.5-7), Plutarco descreve em pormenor este objecto e respectivo uso.

44 Já desde a entrevista de Sólon e Creso, narrada por Heródoto (1.29-30), que é usual colocar questóes aos Sete Sábios no 
- E o rei dos Etíopes encontrou a resposta e a solução para cada um desses enigmas?

- Aqui estáo as respostas; - respondeu Nilóxeno — julgai por vós mesmos, depois de haverdes escutado.

I53A Com efeito, o Faraó faz muita questão de não ser acusado de agir de má fé relativamente às respostas dadas, mas no caso de se verificar que o rei etíope errou alguma das soluçôes, também não deseja que a falha passe sem ser assinalada. Vou, portanto, ler as respostas tal como foram dadas:

O que é a coisa mais velha? - $\mathrm{O}$ tempo.

O que é a coisa mais extensa? - $\mathrm{O}$ universo.

O que é a coisa mais sábia? - A verdade.

O que é a coisa mais bela? - A luz.

O que é a coisa mais comum? - A morte.

O que é a coisa mais útil? - $\mathrm{O}$ deus.

O que é a coisa mais prejudicial? - $\mathrm{O}$ demónio. ${ }^{45}$

O que é a coisa mais poderosa? - A Fortuna.

O que é a coisa mais fácil? - O prazer.

9. Uma vez terminada esta nova leitura, Nicarco, fez-se silêncio e Tales perguntou então a Nilóxeno, se Âmasis tinha aprovado as soluções apresentadas. Ele

superlativo. No caso de Creso, a pergunta do monarca lídio consistia em procurar saber qual seria, na opiniâo do legislador ateniense, o mais feliz dos homens.

${ }^{45}$ A oposição entre 'deus' ( $\theta \in$ Eós) e 'demónio' ( $\left.\delta a i ́ \mu \omega \nu\right)$ mostra que, no tempo de Plutarco, o termo $\delta a i ́ \mu \omega \nu$ já se havia entretanto afastado das acepçóes positivas de 'divindade' para privilegiar uma conotação negativa de 'espírito maligno' ou 'demónio'; o estádio intermédio consiste em considerar os $\delta a i ́ \mu \omega \nu \in \mathrm{s}$ como 'divindades menores', ocupando de certa forma um posto entre a humanidade e os deuses. 
respondeu que umas lhe tinham agradado, mas que outras o tinham deixado insatisfeito.

— Na realidade, — retorquiu Tales — nenhuma das soluçôes é inatacável e todas elas revelam graves erros e ignorância. Por exemplo e para começarmos já pela primeira, como pode o tempo ser a coisa mais velha, se uma parte dele é passado, outra presente e outra ainda futuro? Com efeito, o tempo que virá depois de nós até pode parecer mais novo do que as coisas e as pessoas que existem neste momento. Quanto a sustentar que a verdade corresponde à sabedoria, tenho para mim que isso não difere de afirmar que a luz coincide com o olho. Por outro lado, se declara que a luz é bela, porque não considera antes o próprio sol? Entre as outras respostas, as que se referem aos deuses e aos demónios tanto revelam afoiteza como temeridade. Já a que diz respeito à Fortuna denota sobretudo uma enorme falta de lógica: com efeito, ela não se alteraria com tamanha ligeireza, se fosse mesmo a mais forte e poderosa das coisas existentes. Aliás, nem a morte é a mais comum das coisas, pois nada tem a ver com os vivos. ${ }^{46}$

No entanto, para não passarmos a ideia de que apenas emitimos juízos sobre as opinióes dos outros, vamos confrontar as nossas respostas com as do rei da Etiópia. Ofereço-me até em primeiro lugar para retorquir a cada uma das questóes, se Nilóxeno estiver

46 Nesta afirmação, tem sido vista uma adaptação da máxi-

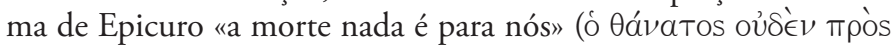

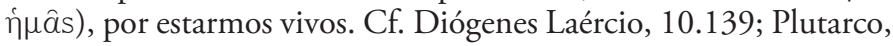
Sobre a forma de entender os poetas, 37a. 
de acordo. Ora seguindo a ordem em que foram colocadas, vou eu também agora enumerar as perguntas e as respostas: ${ }^{47}$

O que é a coisa mais velha? - $\mathrm{O}$ deus, - explicou Tales - pois não chegou a ser criado.

O que é a coisa mais extensa? - $\mathrm{O}$ espaço, pois o universo contém as restantes coisas, mas o universo está contido no espaço.

$\mathrm{O}$ que é a coisa mais bela? - $\mathrm{O}$ universo, pois dele faz parte tudo o que está ordenado.

O que é a coisa mais sábia? - O tempo, pois descobriu já algumas realidades e as outras irá descobri-las no futuro.

O que é a coisa mais comum? - A esperança, pois continua a possuí-la mesmo quem nada mais possui.

O que é a coisa mais útil? - A virtude, pois ao ensinar a fazer bom uso das coisas, torna-as úteis.

$\mathrm{O}$ que é a coisa mais prejudicial? - $\mathrm{O}$ vício, pois estraga as coisas boas pelo simples facto de estar presente.

O que é a coisa mais forte? - A necessidade, pois ela apenas é invencível.

O que é a coisa mais fácil? - Agir segundo as inclinaçôes da natureza, pois até os prazeres atraem muitas vezes a saciedade.

10. Depois de havermos todos manifestado a nossa aprovação a Tales, Cleodoro comentou:

- Ora aqui estáo as perguntas e respostas que

${ }^{47}$ Seja por opção de Tales ou entâo por descuido de algum copista, há algumas variaçóes de pormenor, em especial a troca de ordem entre a terceira e a quarta perguntas. 
convém transmitir aos reis, Nilóxeno. No entanto, para o bárbaro que convidou Âmasis a beber o mar ajustar-se-ia melhor a concisão com que Pítaco retorquiu a Aliates, quando este deu, por escrito, determinada ordem aos habitantes de Lesbos, em tom desdenhoso. De facto, como resposta nada mais lhe disse, a não ser convidá-lo a comer cebolas e pão quente. ${ }^{48}$

Periandro tomou igualmente a palavra, para dizer:

- Mas também os antigos Helenos cultivavam o costume, Cleodoro, de colocarem uns aos outros problemas desta natureza. Com efeito, ouvimos dizer que, por altura das celebraçóes fúnebres em honra de Anfidamante, se reuniram em Cálcis os mais ilustres poetas então existentes. Ora Anfidamante era um homem de armas que havia infligido aos Erétrios pesados trabalhos, até perecer numa das batalhas travadas durante a disputa da planície de Lelanto. Contudo, porque os versos compostos pelos poetas tornavam árdua $\mathrm{e}$ difícil a decisão, devido ao facto de serem de qualidade semelhante, além de que a fama dos concorrentes causava uma enorme dificuldade e embaraço aos juízes, estes resolveram recorrer a perguntas daquele tipo..$^{49}$ Ao

${ }^{48}$ Aliates, pai de Creso, foi o penúltimo rei da Lídia, entre finais do séc. VII e a primeira metade do séc. VI a.C. Às campanhas por ele empreendidas se deve a afirmação do poder lídio. A

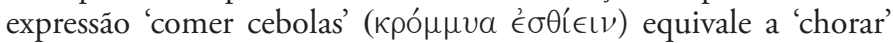
$(\kappa \lambda a i \epsilon t \nu)$, pois as cebolas produzem geralmente esse efeito. Por conseguinte, a resposta de Pítaco (atribuída a Bias de Priene por Diógenes Laércio, 1.83) corresponderia, em português, a uma expressão do tipo "mandar passear".

${ }^{49} \mathrm{Os}$ manuscritos transmitem, neste ponto, os nomes de Homero e Hesíodo, ecoando a tradição de um hipotético Certamen entre estes dois poetas, mas cuja autenticidade já na antiguidade 
que dizem, Lesques terá colocado a seguinte questáo:

Fala-me, ó Musa, das coisas que não aconteceram nunca

[no passado

e no futuro jamais acontecerão.

Ao que Hesíodo respondeu, logo de improviso:

Mas quando à volta do túmulo de Zeus os cavalos de cascos

[sonoros

esfacelarem os carros, no afã de lutarem pela vitória. ${ }^{50}$

E diz-se que, com esta resposta, ele terá suscitado uma enorme admiração e arrebatado a trípode da vitória.

- Mas que diferença há então — ripostou Cleodoro - entre estas perguntas enigmáticas e as adivinhas

era posta em causa, com fundamentadas razóes. De resto, o próprio Plutarco mostra estar consciente, noutros pontos da sua obra (No banquete, 674f; Comentário a Hesiodo, 654-662, frg. 84 SAN$\mathrm{DBACH})$, que aqueles poetas não foram contemporâneos e que a referência a Homero, Hesíodo e Anfidamante seria uma invenção. Já quanto a Lesques de Mitilene, autor de uma Pequena Ilía$d a$, é de admitir que poderia talvez ter participado nas celebraçôes fúnebres em honra de Anfidamante (caído na batalha de Lelanto, no séc. VIII a.C.) e que, segundo alguns autores, estaria eventualmente em condiçôes de disputar o prémio no Certamen, cuja origem, de resto, já os antigos justificavam como uma interpretação abusiva de um passo dos Trabalhos e Dias (vv. 654 sqq.) de Hesíodo. Há que sublinhar, em todo o caso, que as dificuldades cronológicas devem ser relativizadas num tratado como o Banquete dos Sete Sábios, que constitui em si mesmo uma irrealidade histórica da qual Plutarco também estava consciente.

${ }^{50}$ Embora a interpretação destes versos seja objecto de alguma disputa, o facto de Hesíodo se referir ao túmulo de um deus (e portanto de alguém imortal) parece corresponder ao adynaton proposto por Lesques. 
de Eumétis? Não será descabido que ela brinque com as palavras e as entreteça, da mesma forma que outras jovens exibem cinturôes e fitas para o cabelo, mas é ridícula a ideia de pensar que homens providos de bom senso as levem a sério.

Ora Eumétis bem que gostaria de lhe responder, a avaliar pela sua reacção, mas preferiu conter-se, por recato, ao mesmo tempo que o rosto se lhe cobria de rubor. Então Esopo, como quem tomava a defesa dela, retorquiu: ${ }^{51}$

— E não será mais ridículo ainda que não sejamos capazes de solucionar esses enigmas? Tomemos pois, a título de exemplo, a adivinha que ela nos lançou pouco antes do jantar:

Vi um homem a soldar, com o fogo, bronze sobre outro

[homem. ${ }^{52}$

Serás capaz de dizer do que se trata?

- Não faço ideia, nem tenho interesse em saber! - Respondeu Cleodoro.

- E em todo o caso - continuou Esopo - ninC guém o sabe fazer melhor do que tu. E se negares, tenho aqui estas ventosas para servirem de testemunhas. ${ }^{53}$

${ }^{51}$ Sobre o significado desta intervenção de Esopo em favor de Cleobulina, vide supra Introduçáo, secção 6 .

${ }^{52}$ As fontes concordam em atribuir a Cleobulina/Eumétis a autoria deste hexâmetro, se bem que Aristóteles o cite, de forma anónima (Retórica, 1405b; Poética, 1458a), para exemplificar o tipo de metáfora que está por detrás das adivinhas.

${ }^{53} \mathrm{Em}$ vez da palavra mais usual para designar as 'ventosas' ou

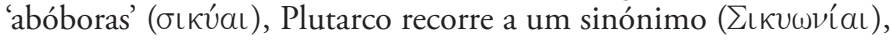


Neste ponto, Cleodoro desatou a rir. Com efeito, entre os médicos do seu tempo, era ele quem fazia um maior uso de ventosas, sendo aliás o responsável pela fama nada pequena que esta prática adquiriu.

11. O ateniense Mnesífilo, que era companheiro e grande admirador de Sólon, disse: ${ }^{54}$

- Pela minha parte, Periandro, acho correcto que a conversa, tal como o vinho, seja repartida não de acordo com a riqueza e a nobreza de nascimento, mas antes por todos em igual medida, como acontece em democracia, e ainda que seja um bem comum. Aliás, o que foi dito agora mesmo sobre o poder e a realeza nada tem que ver conD nosco, pois temos uma sensibilidade democrática. Desta forma, somos de opiniáo que haveria vantagem em que cada um de vós expusesse novamente a sua visão sobre o governo democrático, começando outra vez por Sólon.

Concordou-se em proceder desta forma e Sólon tomou então a palavra em primeiro lugar:

- Em todo o caso, Mnesífilo, tanto tu como os restantes Atenienses já conhecem a perspectiva que eu tenho em relação à forma de conduzir o governo. Ainda assim, se estiveres na disposição de me escutar de novo,

que designa, igualmente, os habitantes de Sícion. Obtém, assim, um jogo de palavras intraduzível em português, a não ser numa eventual alusão irónica a 'cabeças de abóbora', se bem que se perca à mesma a relação com a ideia de 'aplicar ventosas'.

${ }^{54} \mathrm{Na}$ Vida de Temistocles (2.6), Plutarco fornece mais alguns dados sobre este Mnesífilo, ligando-o à formação de Temístocles em termos semelhantes àqueles com que, neste passo, é relacionado com Sólon. De resto, Plutarco inscreve-o claramente numa escola derivada do antigo legislador, identificada com um tipo de sophia que se traduzia em pragmatismo e habilidade aplicados na acçáo política. 
tenho para mim que terá maior sucesso e conseguirá preservar melhor a democracia, a pólis na qual as partes não lesadas perseguem e punem o infractor com zelo não inferior ao da parte efectivamente lesada. ${ }^{55}$

Bias falou em segundo lugar, para dizer que a democracia mais forte era aquela em que todos receiam a lei como se um tirano fosse. Em seguida, Tales sublinhou a importância de nela não existirem cidadãos nem demasiado ricos nem demasiado pobres. Depois dele, Anacársis acrescentou que seria melhor a pólis na qual a igualdade se reflectia na forma de repartir todas as coisas, mas também onde a superioridade se definia pela excelência e a baixeza pelo vício. Em quinto lugar, interveio Cleobulo, para sustentar que o governo popular mostrava maior ponderação quando os políticos receavam mais a censura do que a própria lei. Em sexto, Pítaco defendeu que a liderança era mais eficaz quando os malvados náo podiam governar e as pessoas de bem não podiam deixar de governar. Quílon virou-se ${ }^{56}$ e sustentou, pelo contrário, que era melhor a forma de governo que maior consideração dispensava às leis e menor importância

${ }^{55}$ Embora esta medida não surja no contexto do regime democrático (que é obviamente posterior a Sólon), ainda assim Plutarco está a referir uma das medidas mais importantes do legislador ateniense: a possibilidade de qualquer cidadão (ho boulomenos) poder dar início à quase totalidade dos processos, independentemente de ser ou não a parte lesada. Esta novidade do código de Sólon, registada também por Plutarco na biografia do legislador (Vida de Sólon, 18.6-7), permitia que os cidadãos mais fracos pudessem ser socorridos indirectamente, facilitando assim uma aplicação mais imparcial da justiça.

${ }^{56}$ É duvidosa a lição $\mu \in T \alpha T \rho a \pi \in$ ís. 
dava aos oradores. Por fim, coube a Periandro concluir novamente a discussão, com o argumento decisivo de que lhe parecia que todos eles louvavam um F regime democrático que se parecia o mais possível com a aristocracia.

12. Quando terminou a discussão à volta deste tema, eu mesmo tratei de realçar que me parecia particularmente útil que estes sábios nos falassem sobre a melhor forma de administrar a casa de cada um:

- Com efeito, poucos estáo ao leme de reinos e póleis, mas a todos nós cabe a tarefa de zelar por um lar e pela casa.

Esopo soltou então uma gargalhada e disse:

- Nem todos, se nesse número incluíres também Anacársis. De facto, não apenas ele não possui casa própria, como até se gloria de não a possuir e de usar um carro, tal como o Sol, que, segundo contam, descreve o seu percurso em cima de um carro e ocupando uma após outra as regiôes do céu. ${ }^{57}$

- E por essa mesma razão — retorquiu Anacársis - é se não o único, pelo menos o mais livre e independente dos deuses, pois sobre todos governa e por ninguém é governado, mas antes reina e detém as rédeas. Apenas tu pareces não ter consciência da extraordinária beleza desse carro e da sua imponente dimensão: de

${ }^{57}$ A ideia do Carro do Sol é já bastante antiga; cf. frg. 12 WeST de Mimnermo (poeta de Cólofon, sécs. VII-VI a.C.). Anacársis partilhava com os Citas em geral o facto de serem uma população nómada e de, por isso mesmo, não possuírem residência fixa, na medida em que isso poderia coarctar a sua liberdade de movimentos, que os Citas muito apreciavam. Cf. Heródoto, 4.46. 
outra forma, não o terias comparado comigo, mesmo a brincar e para provocar o riso. Aliás, parece-me que a tua ideia de casa, Esopo, assenta nas coberturas feitas de argamassa, madeira e argila, como se considerasses a concha o próprio caracol e não o animal em si. Por conseguinte, é natural que Sólon te haja feito rir, na medida em que, depois de ter observado a casa de Creso, tão faustosamente adornada, ele não declarou de imediato que o seu proprietário e morador deveria ser uma pessoa feliz e ditosa, pois desejava contemplar, em vez disso, os bens que Creso possuía dentro de si e não os que tinha à sua volta. ${ }^{58}$ Aliás, parece-me inclusive que não te recordas sequer da raposa da tua fábula. ${ }^{59}$ Com efeito, disputando ela com um leopardo sobre quem teria um aspecto mais variegado, pediu ao juiz para ter em linha de conta o seu interior, pois segundo essa perspectiva seria ela a mais variegada. Ora tu examinas o trabalho de carpinteiros e pedreiros, na convicção de que será isso que faz uma casa, em vez de prestares atenção ao que se encontra no interior de cada uma e que é

58 Plutarco refere-se, naturalmente, à famosa pergunta colocada por Creso a Sólon, sobre qual seria o mais feliz dos homens. Na biografia do estadista ateniense (Vida de Sólon, 28.1), Plutarco sustenta que Esopo estaria presente na altura em que os dois homens haviam travado o suposto diálogo, pesem embora as dificuldades cronológicas levantadas por esse encontro, das quais o biógrafo mostra, aliás, ter plena consciência. No relato de Heródoto (1.30-33), a ideia é que se deve suspender o juízo sobre alguém até conhecer o termo da sua vida. Já a argumentação de Anacársis aponta antes no sentido de que contam mais os bens interiores do que as riquezas de que se dispóe.

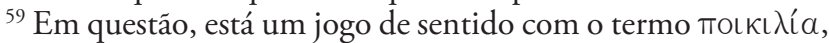
que tanto pode significar a 'versatilidade da mente' (caso da raposa) como as 'cores variegadas' (caso do leopardo). 
próprio dela: os filhos, a esposa, os amigos e servos. Então, mesmo que habitem um formigueiro ou um ninho, se os ocupantes forem pessoas de bom senso e ponderadas, o senhor que com eles partilha as posses mora numa casa afortunada e ditosa. Esta é portanto - continuou ele - a minha resposta ao comentário de Esopo e este o meu contributo à interpelação de Díocles. É justo, porém, que cada um dos outros apresente a própria opinião.

No seguimento, Sólon disse que, para ele, a melhor casa era aquela onde não houvesse injustiça ao adquirir os bens, nem desconfiança ao protegê-los, nem arrependimento ao gastá-los. ${ }^{60} \mathrm{E}$ Bias acrescentou:

- É aquela onde o senhor da casa mostra, de seu natural, o mesmo carácter que apresenta fora, na observância da lei.

D _ É aquela — sublinhou Tales — onde o senhor da casa pode encontrar o maior sossego.

Cleobulo disse que era aquela onde o senhor da casa encontra mais pessoas que gostem dele do que dele tenham receio.

— A melhor casa é aquela — reforçou Pítaco — que não precisa de nada de supérfluo e onde nada falta do necessário.

Quílon disse que uma casa se deveria assemelhar em especial a uma cidade governada por um rei e terminou acrescentando que Licurgo havia dado a

${ }^{60}$ Esta forma de lidar com a riqueza encontra-se também nos poemas de Sólon (e.g. frg. 13.7-13 WeST) e é sublinhada igualmente por Plutarco na biografia do estadista ateniense (Vida de Sólon, 2.3-4). 
seguinte resposta aos que insistiam para ele instaurar uma democracia na pólis: "Criai primeiro uma democracia na vossa própria casa!»

13. Depois de também esta discussão haver chegado ao fim, Eumétis afastou-se, na companhia de Melissa. E porque Periandro ofereceu a Quílon de beber por uma taça de considerável dimensão e Quílon fez o mesmo em relação a Bias, Árdalo levantou-se e fez o seguinte comentário para Esopo:

- Então tu não poderias mandar aqui para o nosso lado essa taça, pois vejo que eles a passaram de uns para os outros, como se fosse a taça de Báticles, mas não a entregam a mais ninguém? ${ }^{61}$

- Mas esta taça - retorquiu Esopo - não foi feita para o povo! Na verdade, há uma data de tempo já que não sai de ao pé de Sólon!

Pítaco dirigiu-se então a Mnesífilo e perguntou-lhe por que motivo Sólon não bebia, pois estava assim a desacreditar os próprios versos que ele próprio escrevera: ${ }^{62}$

${ }^{61}$ Não é segura a identidade deste Báticles, mas alguns estudiosos defendem que será de identificá-lo com o escultor homónimo de Magnésia. O mesmo Plutarco (Vida de Sólon, 4) recorda não só a taça de Báticles, como refere outra tradição, segundo a qual o objecto em causa seria uma trípode. $\mathrm{Na}$ base do relato, reportado com variantes por muitas outras fontes, está a ideia de que, devendo a trípode (ou a taça) ser entregue ao homem mais sábio, os Sapientes a foram enviando uns aos outros, até que o objecto voltou ao ponto de partida, acabando por ser consagrado a Apolo. Além da natural modéstia que deve caracterizar um verdadeiro sábio, a história espelha também a ligação entre os Sete Sábios e o imaginário délfico.

${ }^{62}$ Frg. 26 West. 
As obras da Cípria me são gratas agora, e as de Diónisos e das Musas, que trazem aos homens alegrias.

- Na verdade, - preveniu-o Anacársis - é a ti e àquela tua dura lei que ele receia, segundo a qual decretaste que «se alguém comete alguma infracção em estado de embriaguez, enfrenta uma punição dupla relativamente a quem esteja sóbrio». ${ }^{63}$

- Tu, pelo contrário, — retorquiu Pítaco mostraste um tal desprezo por essa lei que, no ano passado, na casa de Lábis em Delfos, não só te embebedaste, como ainda te puseste a exigir uma coroa como prémio. $^{64}$

E porque não? — retorquiu Anacársis — Pois se haviam estabelecido prémios para quem mais bebesse e se eu fui o primeiro a embebedar-me, não deveria eu reclamar o galardão da vitória? A não ser assim,

${ }^{63}$ Esta lei de Pítaco contra o consumo excessivo de vinho aparece em várias outras fontes; e.g. Aristóteles, Política, 1274b; Ética a Nicómaco, 1113b30-35; Retórica, 2.25.1402b. A explicação que o Estagirita avança na Ética a Nicómaco é particularmente curiosa: a infracção é dupla, na medida em que, além do acto em si, há que ter em conta a opçáo deliberada de ter provocado, pelo excesso de vinho, o estado de inconsciência que levou a que a falta fosse cometida. Por conseguinte, em vez de ser um factor que pode atenuar a infracçáo, a embriaguez constitui, pelo contrário, uma nota agravante na avaliação da conduta do faltoso.

${ }^{64}$ Lábis seria um eunuco encarregado de guardar o santuário de Apolo em Delfos, ao qual vem igualmente atribuída a autoria da

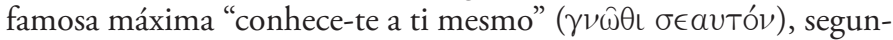
do o comentário de um escoliasta a Platáo (schol. Plat. Phlb., 48c). Ateneu (10.438) refere o mesmo episódio, se bem que no decurso de um banquete dado por Periandro. 
explicai-me lá que outro fim existirá em beber vinho puro a não ser apanhar uma bebedeira?

Pítaco desatou a rir e Esopo resolveu então contar a seguinte fábula:

- Um lobo surpreendeu alguns pastores a comer uma ovelha na sua cabana. Aproximou-se então e comentou: "Que algazarra iríeis vós armar, se fosse eu a fazer isso!»

—É com toda a legitimidade — atalhou Quílon — que Esopo se coloca na defensiva, pois ainda há bem pouco tempo nós lhe tirámos a palavra ${ }^{65}$ e ele vê que agora outros estão a interromper Mnesífilo. Com efeito, era a Mnesífilo que se tinha pedido um comentário relativo a Sólon.

- Falarei então - disse Mnesífilo ${ }^{66}$ - com pleB na consciência de que, para Sólon, a obra de toda a arte e capacidade, tanto humana como divina, consiste mais no que é criado do que na maneira como se chega à criação, portanto no fim em si e não tanto nos meios para se atingir o fim. Com efeito, suponho que um teceláo veria mais como obra sua uma clâmide ou um manto, do que a disposição da trama sobre os roletes ou a tensão dos pesos; um ferreiro, olharia mais à soldadura do ferro ou à têmpera do machado, do que a qualquer uma das acçóes necessárias para obter este efeito, como sejam avivar as brasas do carvão ou

${ }^{65}$ Cf. supra 152 d, onde Sólon criticara a Esopo a tendência para a loquacidade.

${ }^{66}$ Apesar de veicular teoricamente as ideias de Sólon, o discurso de Mnesífilo acusa sobretudo a influência do pensamento platónico. 
preparar o pó de pedra. ${ }^{67}$ Aliás, seria maior ainda o protesto de um arquitecto, se nós afirmássemos que a sua obra consistia não em construir um barco ou uma casa, mas antes em perfurar barrotes e preparar argamassa. E outro tanto fariam seguramente as Musas, se c considerássemos que a sua obra correspondia apenas à cítara e às flautas, e não à educação dos caracteres e à moderação das paixões de quantos desfrutam de cânticos e harmonias. Da mesma forma, a obra de Afrodite não se esgota na relação sexual e na cópula, nem a de Diónisos na bebedeira e no vinho, mas antes em usar estes meios para promover a amizade, o desejo, o companheirismo e a intimidade entre uns e os outros. É a estas obras que Sólon chama "obras divinas" e também são estas que ele ama e persegue, em especial depois de se haver tornado anciāo. Afrodite é obreira da concórdia e da amizade entre homens e mulheres, ao misturar e fundir as almas com os corpos, por

D intermédio do prazer. ${ }^{68}$ Mas para a maior parte das pessoas, que de todo não possuem intimidade entre si ou não se conhecem muito bem, então é Diónisos quem, à semelhança do fogo, lhes dulcifica e amacia os caracteres, servindo-se do vinho para dar início à união e amizade entre uns e outros. Contudo, quando se reúnem homens com a vossa qualidade e que

${ }^{67}$ A função do pó de pedra ou cascalho para arrefecer o ferro é esclarecida pelo mesmo Plutarco no tratado Sobre o frio primordial, $954 \mathrm{a}-\mathrm{b}$.

${ }^{68}$ Plutarco exalta sobretudo o amor heterossexual. Relativamente à imagem aqui usada, cf. Platão, Banquete, 192d; e ainda o mesmo Plutarco, Sobre o amor, 752d, 769a. 
Periandro aqui juntou, não creio que haja necessidade de taças nem de vasos para servir o vinho, pois as Musas, ao colocarem à disposição de todos, como se fosse um grande vaso de mistura sem vinho, ${ }^{69}$ a conversa, que em si mesma contém o máximo de prazer, juntamente com boa disposição e seriedade, com ela despertam, irrigam e difundem a bondade, deixando jazer imóvel a maior parte do tempo o vaso de servir "em cima do vaso de mistura» - precisamente aquilo que Hesíodo proibia de fazer na companhia de pessoas que apreciassem mais a bebida do que o diálogo. ${ }^{70}$ Quanto aos brindes e votos - concluiu Mnesífilo - posso dizer que.${ }^{71}$ entre os antigos se deitava o vinho «à porção», como sustentava Homero. ${ }^{72} \mathrm{E}$ ainda que cada um deve beber com mesura, e em seguida, como se faz com a carne, há que passar uma parte ao vizinho do lado.

${ }^{69}$ No tratado Sobre o desaparecimento dos oráculos (421a), Plutarco retoma a imagem do 'vaso de mistura sem vinho', mas repleto de mitos e discursos com que os convidas podem brindar entre si.

${ }^{70}$ Cf. Hesíodo, Trabalhos e Dias, 744. Plutarco utiliza neste momento termos próprios dos utensílios usados em contexto de banquete, como o 'vaso de servir' o vinho aos convidados

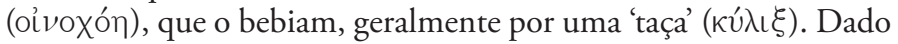
que, entre os Gregos, era considerado impróprio beber vinho puro, havia um recipiente de grande capacidade para se proceder a essa

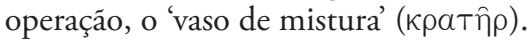

${ }^{71}$ Os manuscritos apresentam uma lacuna, de dimensão talvez relativamente extensa, cuja reconstituição é problemática e torna particularmente difícil a interpretação deste passo. É possível mas náo seguro que, com esta intervenção final, Mnesífilo se quisesse talvez desculpar da relativa extensăo do seu discurso, ao mesmo tempo que procuraria sublinhar a necessidade de beber com moderação.

\footnotetext{
${ }^{72}$ Ilíada, 4.262.
} 
Depois de Mnesífilo ter feito esta intervenção, o poeta Quérsias (que se livrara entretanto da acusaçáo, tendo-se recentemente reconciliado com Periandro, por insistência de Quílon) comentou: ${ }^{73}$

- Sendo assim, também Zeus servia bebida aos F deuses com moderação, da mesma forma que Agamémnon o fazia em relação aos guerreiros mais nobres, quando as divindades trocavam brindes entre si, ao comerem em casa de Zeus?

- Pois então, Quérsias, — respondeu Cleodoro - se a ambrósia é trazida a Zeus por pombos (como vós os poetas afirmais), que só muito a custo conseguem transpor as Rochas Errantes, ${ }^{74}$ não achas que o néctar

I57A também lhe será difícil de obter e raro, de maneira que ele deve ser poupado e oferecê-lo a cada um dos deuses com parcimónia?

14. - Provavelmente, — retorquiu Quérsias mas já que voltámos a falar de economia, qual de vós me pode explicar o que ficou por dizer? Segundo creio,

${ }^{73}$ Segundo Pausânias (9.38.9-10), Quérsias provinha de Orcómeno e seria autor de um epitáfio composto em honra de Hesíodo. Nenhuma outra fonte se refere a esta personagem e, mesmo no Banquete dos Sete Sábios, é estranho que o seu nome não seja referido, quando se apresenta o relato da morte de Hesíodo, feito por Sólon e sem que haja intervenção de mais nenhum conviva (infra 162c-d). Ainda assim, além da alusão agora em causa, diz-se também mais adiante (164b) que ele se encontraria junto de Cípselo quando da consagração do tesouro em Delfos, facto que indicia que ele talvez fosse um dos poetas que circulavam na corte do tirano.

${ }^{74}$ As Rochas Errantes ou Simplégades são referidas pela primeira vez em Homero (Odisseia, 12.61-65) e virão a ter um papel importante na saga dos Argonautas, onde são colocadas à entrada do Ponto Euxino, se bem que os antigos as situassem igualmente no estreito de Messina e nas Ilhas Eólias. 
falta definir ainda em que medida a posse de bens será suficiente para garantir a autonomia.

- Ora no que respeita aos Sábios - esclareceu Cleobulo - essa medida é facultada pela própria lei. Mas para as pessoas vulgares, vou referir uma história que a minha filha expôs ao irmão. Com efeito, contava ela que a Lua pediu à mãe para lhe fazer uma túnica à medida, ao que a mãe respondeu: «Mas como posso eu fazer-te uma túnica à medida? Agora estou a ver-te em lua cheia, noutro dia vejo-te em meia-lua, noutro ainda em quarto crescente.» $\mathrm{O}$ mesmo se passa, meu caro Quérsias, com uma pessoa sem entendimento e vulgar, pois para alguém assim não há qualquer medida para a riqueza: com efeito, ora tem umas necessidades ora outras, que variam segundo os seus desejos e venturas, à semelhança do cão de Esopo. Tal como este nosso amigo conta, durante o inverno o cáo enroscava-se e enrodilhava-se em si mesmo, por causa do frio, e só pensava em construir uma casa. Porém, quando finalmente chegava o tempo quente e ele se encontrava a dormir estendido no chão, achava-se muito grande e pensava que não seria tarefa necessária e também nada pequena construir uma casa daquelas à volta de si mesmo. Pois não vês tu, Quérsias, - concluiu - como as pessoas medíocres em certas alturas se reduzem por completo a uma existência miserável, levando uma vida sóbria, à maneira dos Espartanos, enquanto noutras ocasióes acham que estáo a ponto de morrer de indigência, se não possuírem todos os bens, pertençam eles a simples privados ou aos próprios reis? 
Ora dado que Quérsias se remetia ao silêncio, Cleodoro tomou a palavra e disse:

- Em todo o caso, constatamos que também vós, os Sábios, tendes os bens repartidos de forma desigual, quando comparados uns com os outros.

- Isso acontece - retorquiu Cleobulo - porque a lei, caríssimo amigo, funciona como um tecelão e atribui a cada um de nós o mais conveniente, segundo a justa medida, e o mais apropriado. $\mathrm{O}$ mesmo fazes tu, ao usar a razáo como a lei, quando prescreves alimentos, dietas e mezinhas aos pacientes: não distribuis o mesmo a todos, mas antes destinas a cada um a dose mais apropriada. $^{75}$

Árdalo entrou também na conversa e disse:

- Entáo se calhar existe uma lei que dita ao vosso companheiro Epiménides, hóspede de Sólon, para se abster de todos os demais alimentos e levar à boca somente um pouco daquela mezinha contra a fome que ele mesmo prepara, passando assim o dia sem almoço nem jantar? ${ }^{76}$

${ }^{75}$ Este mesmo problema da igualdade aritmética (repartir o mesmo por todos) e da igualdade geométrica (repartir por cada um segundo as necessidades) é retomado por Plutarco na obra No banquete (643b), novamente em comparaçáo com as doses de medicamento prescritas pelos médicos. Em No banquete, o biógrafo pende para a primeira solução, mas no tratado Sobre o amor fraterno (484b), dá preferência à segunda hipótese.

${ }^{76}$ Epiménides era originário de Creta (das localidades de Festo ou de Cnossos) e tinha fama de taumaturgo, ao qual se recorria sobretudo para proceder a purificaçóes rituais. Terá sido nessa condição que foi convidado para vir a Atenas, a fim de livrar a cidade do miasma provocado pela morte sacrílega dos seguidores de Cílon, em finais do séc. VII a.C. De acordo com Diógenes Laércio (1.110), Epiménides teria visitado Atenas na 46a Olimpíada 
Esta observação atraiu a atenção de todos os presentes no banquete e Tales começou por brincar, dizendo que Epiménides dava mostras de bom senso ao não desejar ter trabalho a moer e cozinhar os alimentos para si mesmo, como Pítaco. E acrescentou ainda:

- De facto, quando me encontrava em Éreso, ${ }^{77}$ escutei a mulher minha anfitriã a cantar assim para a pedra da mó:

Mói, mó, mói,

pois também Pítaco mói,

ele que da grande Mitilene soberano é.

Sólon comentou então que ficara admirado por Árdalo não conhecer a norma que regulava a dieta alimentar de Epiménides, e que vem descrita nos versos de Hesíodo:

- De facto, foi ele o primeiro a lançar no espírito de Epiménides as sementes desta forma de alimentação, pois ensinou-o a buscar com afinco

(= 596-592) e Eusébio (Hieron., $v . l l$ 45.4, 46.2) situa essa viagem no segundo ano da mesma Olimpíada (= 595/594). Concordam, portanto, globalmente com Plutarco (Vida de Sólon, 12.7-9), que coloca o evento antes do arcontado do estadista ateniense. No entanto, o biógrafo afirma que Epiménides auxiliou o legislador, o que implicará que aquele tenha permanecido em Atenas durante algum tempo. Além do ascendente em matéria religiosa, Creta gozava ainda de grande fama do ponto de vista jurídico; é de uma das suas cidades que provém um dos documentos mais interessantes do direito grego: o código de Gortina. Teofrasto.

77 Cidade da ilha de Lesbos, de onde eram originários Safo e 
quanta utilidade existe na malva e no asfódelo. ${ }^{78}$

- És portanto de opinião — atalhou Periandro - que Hesíodo tinha esse desígnio em mente e não tanto que, sendo ele sempre um grande partidário da sobriedade, nos estaria antes a recomendar a utilização de nutrimentos mais simples, por serem também mais F agradáveis? $\mathrm{Na}$ realidade, a malva é boa para comer e o talo do asfódelo tem um sabor doce. Mas os tais produtos contra a fome e contra a sede (que são mais uma mezinha do que um alimento) levam, tanto quanto sei, mel e queijo de terras exóticas na sua confecção, bem como sementes de vário tipo que não são fáceis de encontrar. Sendo assim, como poderíamos secundar Hesíodo, ao sustentar que deixa suspenso

o timão ao fumo ${ }^{79}$

e ainda que

cessam as tarefas dos bois e das mulas resistentes à fadiga, ${ }^{80}$

se é necessária uma preparação tão cuidada? Por isso fico I 58A espantado, Sólon, com o facto de, havendo o teu hóspede estado há pouco entre os Délios a conduzir uma

${ }^{78}$ Trabalhos e Dias, 41. A ideia de que o preparado especial de Epiménides fosse composto de malva e asfódelo e de que o taumaturgo havia buscado inspiração em Hesíodo encontra-se noutras fontes dignas de nota, como Platão (Leis, 677d).

79 Trabalhos e Dias, 45.

${ }^{80}$ Trabalhos e Dias, 46. 
grande purificação, ${ }^{81}$ não ter reparado que, entre outras ofertas simples e espontâneas, é usual levar ao santuário, como vestígios e exemplos de uma alimentação primitiva, a malva e o talo do asfódelo, afigurando-se portanto possível que Hesíodo nos esteja a recomendar também a sua enorme simplicidade e temperança.

— E não é só isso, - continuou Anacársis pois ambas estas plantas são apreciadas sobretudo pelas suas virtudes salutares.

— Tens toda a razão. — corroborou Cleodoro $\mathrm{Na}$ realidade, Hesíodo deve ter conhecimentos de medicina, como ilustra claramente o facto de ele não mostrar descuido ou falta de experiência na maneira como discorre sobre o regime alimentar, a mistura do vinho, as virtudes da água, o banho das mulheres, bem como sobre a melhor altura para ter relaçóes sexuais ou sobre a forma de acomodar os recém-nascidos. ${ }^{82}$ Em todo o caso, parece-me que Esopo poderá com maior propriedade do que Epiménides reclamar para si o título de discípulo de Hesíodo. Com efeito, foi a fábula do rouxinol e do falcão que lhe serviu de ponto de partida para esta bela sabedoria, tão variada e proferida por mil vozes. ${ }^{83}$ Mas eu escutaria de bom grado Sólon. Com efeito,

${ }^{81}$ É possível, mas não seguro, que a purificação agora referida seja a que foi ordenada por Pisístrato. Cf. Heródoto, 1.64; Tucídides, 3.104.

${ }^{82}$ Estas observaçóes indiciam que Plutarco detinha um profundo conhecimento da produção artística de Hesíodo, ideia congruente aliás com a notícia de que o biógrafo teria preparado um comentário à obra do poeta.

${ }^{83}$ Cf. Trabalhos e Dias, 203-212. Apesar de ambos serem representantes da mesma sabedoria popular e intuitiva, Cleodoro 
havendo ele privado com Epiménides tanto tempo em Atenas, é bem capaz de saber que tipo de experiência ou de raciocínio apurado o terão conduzido a um tal regime alimentar.

15. Então Sólon retorquiu nestes moldes:

- Mas que necessidade havia de lhe perguntar uma coisa dessas? $\mathrm{Na}$ realidade, é bem evidente que, depois do sumo bem, a melhor coisa consiste mesmo c em precisar o menos possível de alimentação. ${ }^{84} \mathrm{Ou}$ não achas tu que o bem supremo consiste em não ter qualquer necessidade de alimento?

- De forma alguma, — respondeu Cleodoro se me é permitido manifestar o que penso! E em especial com a mesa assim preparada: ao eliminar o alimento, elimina-se também a mesa, que é um altar aos deuses da amizade e da hospitalidade! Como dizia Tales, ao eliminar a terra, o caos tomaria conta de todo o cosmos; ${ }^{85}$ da mesma forma, também a eliminação da alimentação representaria a dissolução da casa. Com efeito, juntamente com a mesa, elimina-se também o fogo guardião do lar, o próprio lar, os vasos para misturar o vinho, o acolhimento, a hospitalidade, as mais humanas e primeiras manifestaçôes de comunhão entre as pessoas.

mostra mais respeito pelas fábulas de Esopo do que pelas adivinhas de Cleobulina (cf. supra 154a-b).

${ }^{84}$ Segundo Xenofonte (Memoráveis, 1.6.10), Sócrates sustentava que era próprio da natureza divina náo precisar de nada, de forma que o ser humano se aproximava desse estatuto na mesma proporção em que necessitasse de menos coisas.

${ }^{85}$ A ideia de que, com o desaparecimento da terra, o cosmos ficaria mergulhado numa confusão e ruína caóticas é atribuída a Tales apenas neste passo. 
$\mathrm{Na}$ verdade, é eliminar a vida no seu conjunto, se esta corresponde efectivamente a uma forma de o homem passar o tempo e comporta a existência de uma série de acçóes, ${ }^{86}$ motivadas em grande parte pela necessidade de alimentação e respectiva preparação. Por outro lado, seria terrível, caro amigo, a situação da agricultura, condenada juntamente com ela à aniquilação, se deixássemos a terra voltar a um estado selvagem e inculto, ao ser invadida por matas improdutivas e aluviôes descontrolados, por causa da inacção humana. E a esta destruição viria juntar-se também a de todas as artes e actividades, as quais são motivadas pela comida, pois a todas proporciona fundamento e matéria, a ponto de nada mais serem, se ela desaparecer. Acabariam banidas também as honras prestadas aos deuses, na medida em que os homens ficariam pouco gratos ao Sol e ainda menos à Lua, a quem agradeceriam somente o favor da luz e do calor. Onde irá um altar ser dedicado, onde haverá um sacrifício oferecido a Zeus que manda a chuva, a Deméter que dá início às lavouras, a Poséidon que faz brotar as sementes? E Diónisos, como poderá ele dispensar alegrias, se ninguém precisar das graças que ele tem para conceder? Que iremos nós sacrificar ou oferecer em libação? Que iremos tributar como primícias? Ora tudo isto acarreta a destruição e ruína de rituais da maior importância. Com efeito, entregar-se a toda a forma de prazer é uma completa irracionalidade, mas fugir a toda a forma de prazer é também uma insensatez completa! Concedamos,

${ }^{86}$ Esta definição da existência humana acusa a influência do pensamento estóico, tal como é transmitido por Porfírio (apud Estobeu, 2.165.10). 
em todo o caso, que existem outros prazeres de natureza superior dos quais a alma possa desfrutar, mas não há para o corpo forma de gozar um prazer mais justificável do que o que resulta da alimentação — e tal realidade nenhum ser humano a desconhece. Pois este é um prazer que as pessoas expóem à vista de todos, ao partilharem entre si uma refeição à mesa. Os prazeres do amor, pelo contrário, gozam-nos a coberto da noite e das trevas profundas, por acharem que é tão vergonhoso e animalesco partilhar estes deleites quanto não partilhar os primeiros.

Depois de Cleodoro terminar de falar, tomei a palavra e comentei: ${ }^{87}$

- Aliás, acabaste por não dizer que, ao eliminar a alimentação, estaremos a eliminar igualmente o sono.

I59A Ora sem o sono não há sonho e assim desaparece a nossa mais antiga forma de adivinhação. A existência irá tornar-se monótona e, de certa maneira, será em vão que o corpo revestirá a alma. Com efeito, as partes mais numerosas e mais nobres do corpo estáo preparadas para serem os órgãos responsáveis pela nutrição: a boca, os dentes, o estômago e o fígado. Ora nenhum deles é ocioso, nem está programado para outro tipo de funçáo, de maneira que, se uma pessoa não precisar de alimento, não precisará também de corpo. E isto significa não precisar de si mesmo, pois cada um de nós existe unido

${ }^{87}$ Ao contrário de PATON, que assinala uma lacuna neste contexto, a qual dificulta a identificaçáo da pessoa que agora toma a palavra, creio (na esteira de Defradas e de Lo Cascio), que neste ponto o interlocutor pode, efectivamente, ser o narrador e adivinho Díocles, uma vez que se faz referência à adivinhação. Sendo assim,

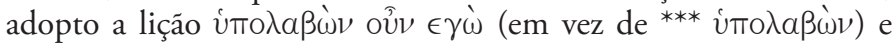

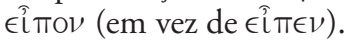


a um corpo. São estes, portanto, — concluí — os argumentos que apresentamos em defesa da barriga. Mas se Sólon ou qualquer outro quiser mover contra ela uma acusação, estamos na disposição de escutar.

16. - Mas com certeza, - respondeu Sólon

- pois não gostaria que mostrássemos menos discernimento que os Egípcios, os quais abrem o cadáver e o expóem ao sol, depois de lhe retirarem as vísceras, que lançam ao rio, tratando somente do restante corpo, como se houvesse já sido purificado. Na verdade, é isto que representa a poluição da nossa carne, uma espécie de Tártaro semelhante ao Hades, repleto de torrentes medonhas, de vento misturado com fogo, de cadáveres. Com efeito, nenhum ser vivo se alimenta de outro ser ainda vivo, e assim, quando matamos um animal ou uma planta, que toma parte na vida enquanto se alimenta e cresce, nós estamos a cometer uma injustiça com essa destruição. De facto, é aniquilado tudo o que vê alterada a sua natureza e se transforma numa coisa diferente, sofrendo uma corrupçáo total, a ponto de tornar-se em alimento para outro ser. Abster-se de comer carne, como se diz que fazia o antigo Orfeu, representa mais um expediente do que uma real fuga às injustiças da alimentação. ${ }^{88}$ Há apenas uma única fuga e

${ }^{88}$ Com efeito, a abstinência de carne acaba por não eliminar a injustiça cometida contra as plantas, que continuam a ver interrompido o seu ciclo de vida. Orfeu era um mítico poeta da Trácia, cuja excelência como cantor lhe permitiu vencer as barreiras do Hades, a fim de resgatar da morte a sua amada Eurídice. Por isso mesmo, Orfeu era símbolo do poder encantatório da música e da poesia. Este mito estava ligado também a uma corrente mistérica que dele retira o nome - o Orfismo - e partilha com o 
uma forma de purificação possíveis: ser completamente autónomo e auto-suficiente. Mas a partir do momento em que a divindade tornou o ser humano incapaz de garantir a própria sobrevivência sem prejudicar o outro, nessa altura estabeleceu também como natural o princípio da injustiça. Pois náo seria correcto, caro amigo, que, juntamente com a injustiça, se cortassem as vísceras, o estômago e o fígado, que náo nos proporcionam nem a sensação nem o desejo de nada de belo, mas antes se parecem com utensílios de cozinha, como se fossem cutelos e caldeiróes, ferramentas de moleiro e de escavaD dor de poços, fornalhas e rolos de amassar? Com efeito, na maior parte das pessoas, a alma parece estar completamente escondida no corpo como se fora um moinho, rodando sempre em volta da premência de comer. Aliás também nós, ainda há pouco, não nos olhávamos nem ouvíamos uns aos outros, pois estávamos todos de cabeça baixa, como se fôssemos escravos da necessidade de alimento. Mas assim que se levantaram as mesas, tornámo-nos livres, como podes constatar, cingimo-nos de coroas e passámos o tempo a conversar, gozando realmente a companhia uns dos outros e estes momentos de vagar, pois conseguimos escapar à premente necessidade da comida. Ora partindo do princípio de que o estado em que nos encontramos agora se manterá como tal até

E ao fim da nossa vida, não teremos nós sempre vagar para estarmos assim uns com os outros, sem recear a pobreza

Pitagorismo alguns traços, como a crença na metempsicose e na abstenção de comer carne animal. Sobre a tradição de o próprio Orfeu haver prescindido desse tipo de alimentos, vide Eurípides, Hipólito, 952-954; Platão, Leis, 782c. 
e sem conhecer a riqueza? Com efeito, a ânsia do supérfluo vem logo a seguir e tende a associar-se à premência do que é necessário.

Em todo o caso, Cleodoro acha que a alimentação deve continuar a existir, para que existam igualmente mesas, vasos para misturar o vinho, bem como sacrifícios a Deméter e a Core. ${ }^{89}$ Outro defenderá ser correcto que haja combates e guerra, a fim de continuarmos a ter fortificaçôes, docas e arsenais, e a oferecer sacrifícios pela morte de cem inimigos, como dizem que é norma entre os Messénios..$^{90}$ Outro ainda poderia, creio eu, lançar uma invectiva contra a saúde e afirmar: "Será terrível que, por não existir mais ninguém doente, não haja utilidade para um cobertor macio ou um leito e se deixe de sacrificar a Asclépio ${ }^{91}$ e aos deuses tutelares, ou ainda que a arte da medicina, juntamente com os seus numerosos utensílios e remédios, fique desprezada a um canto, sem notoriedade e caída em desuso?». Ora que diferença há entre esta argumentação e a vossa?

${ }^{89}$ Deméter e a sua 'filha' (Core) ou Perséfone estấo directamente ligadas a rituais agrários de fertilidade; os mistérios de Elêusis, onde eram objecto de adoraçấo especial, constituíam um dos cultos iniciáticos mais importantes da Grécia.

${ }^{90} \mathrm{Na}$ Vida de Rómulo (25.4), Plutarco refere igualmente, com alguma ponta de cepticismo, a história de que Aristómenes, o tradicional herói da resistência de Messénia à invasão espartana ligada provavelmente à Segunda Guerra Messénica (c. 650 a.C.), teria oferecido por três vezes sacrifícios por haver morto cem inimigos. Cf. ainda o mesmo Plutarco, No banquete, 660f; Pausânias, 4.19.2 -3 .

${ }^{91}$ Filho de Apolo e da ninfa Corónis, Asclépio aprendeu a arte da medicina com o centauro Quíron. O culto de Asclépio conheceria um forte incremento a partir do séc. $V$ a.C., tendo em Epidauro um santuário que atraía pessoas de todo o mundo grego. 
Com efeito, a alimentação funciona como remédio para a fome e assim pode dizer-se de todos os que consomem a comida segundo a dieta prescrita que estáo, I60A na verdade, a curar-se a si mesmos, agindo assim não por ser uma coisa deliciosa e agradável, mas antes em obediência à necessidade e à própria natureza. Aliás, podem enumerar-se mais incómodos do que prazeres gerados pela alimentação; ou melhor dizendo, o prazer contenta uma área limitada do corpo e durante um curto espaço de tempo, ao passo que o trabalho e incómodo ligados à sua digestão — será preciso lembrá-lo? — nos enchem de vergonhas e dores tamanhas! ${ }^{92}$ Penso, de resto, que Homero tinha estas consideraçóes em vista, quando, para demonstrar a imortalidade dos deuses, avançou o argumento de que eles não precisavam de se alimentar: ${ }^{93}$

Pois eles não comem pão, nem bebem o vinho cor de fogo, e por esse motivo não possuem sangue e são chamados

[imortais.

Com isto pretendia sustentar que a comida é não só um meio para garantir a vida, mas também para encontrar a morte. Devido a ela, com efeito, as doenças alimentam-se juntamente com o corpo, a ponto de a saciedade não ser um mal menor do que a fome. Muitas vezes, dá menos trabalho encontrar e reunir

${ }^{92}$ Com a entrada de Gorgo, os argumentos de Sólon relativos às desvantagens da comida acabarão por ficar sem réplica, pois o assunto será abandonado.

${ }^{93}$ Ilíada, 5.341-342. 
alimento do que digeri-lo e evacuá-lo novamente, depois de haver sido introduzido no corpo. Porém, tal como as Danaides ${ }^{94}$ não saberiam que vida levar ou o que fazer, se fossem libertadas da servil tarefa de encherem o pote, também nós cairíamos na incerteza, se por acaso pudéssemos deixar de levar à nossa carne insaciável toda esta quantidade de produtos arrancados à terra e ao mar. E ficaríamos sem saber o que fazer, já que, por falta de experiência das coisas belas, nós nos contentamos com uma existência dedicada apenas às necessidades. Outro tanto acontece, precisamente, com os escravos, quando são libertados, pois continuam a fazer, por iniciativa própria, o que dantes faziam quando estavam às ordens dos seus senhores. Da mesma forma, a alma trata agora de alimentar o corpo, com enormes canseiras e dificuldades, mas ao livrar-se dessa servidão e ao alcançar a verdadeira liberdade, iria alimentar-se a si própria e viveria com os olhos postos em si mesma e na verdade, sem que nada a fosse distrair ou desviar desse propósito. ${ }^{95}$

- E foram estas, caro Nicarco, as opinióes expressas no respeitante à alimentação.

${ }^{94}$ As cinquenta filhas de Dânao estão ligadas não só ao surgimento da raça dos Dânaos (que veio substituir a dos Pelasgos), mas também ao assassínio violento dos primeiros maridos. Como punição para este crime, receberam no Hades a incumbência de eternamente tentarem encher com água um recipiente sem fundo.

95 As palavras de Sólon têm óbvias ligaçóes com a argumentação usada por Sócrates no Fédon (64a-67b) de Platão, se bem que Plutarco náo diga, de forma clara, que a morte será um estado melhor do que a vida, por permitir à alma dedicar-se por inteiro à indagação da verdade. 
17. Ainda Sólon estava a falar quando entrou Gorgo, o irmão de Periandro. ${ }^{96}$ Com efeito, havia sido enviado a Ténaro, na sequência de certos oráculos, com a missão de conduzir uma embaixada e de fazer sacrifícios a Poséidon. ${ }^{97}$ Todos nós o saudámos, enquanto Periandro o abraçou e beijou. Depois disso, Gorgo sentou-se junto ao irmão, no leito, e pôs-se a fazer um relato dirigido a ele somente. À medida que ia escutando, Periandro dava mostras de estar profundamente impressionado com a narração. Com efeito, umas vezes parecia preocupado, outras indignado, e muitas outras incrédulo e em seguida maravilhado. Por fim, soltou uma gargalhada, voltou-se para nós e disse:

- Dadas as circunstâncias, gostaria de contar-vos o que acabou de me ser narrado, mas continuo a hesitar, E pois ouvi uma vez a Tales a observação de que se deve relatar o que se afigura plausível, sendo que o impossível ficará melhor guardado em silêncio.

Então, Bias tomou a palavra e fez o seguinte reparo:

- Mas também pertence a Tales esta sábia máxima: «aos inimigos não se deve dar crédito mesmo nas coisas credíveis, enquanto aos amigos deve dar-se crédito mesmo nas coisa incríveis». Segundo penso, ele

${ }^{96}$ Pesem embora as naturais diferenças, este intempestivo ingresso de Gorgo encontra, em termos genéricos, paralelo na forma como Alcibíades faz a sua entrada no banquete de Ágaton. Cf. Platáo, Banquete, 212c sqq. O surgimento desta personagem serve de pretexto para introduzir a história de Aríon, que havia sido salvo por golfinhos. O relato mais antigo da lenda remonta a Heródoto (1.24), que parece ter sido a fonte directa de Plutarco.

${ }^{97}$ Este deus possuía um templo famoso no cabo de Ténaro. 
usou o termo "inimigos" para designar os malvados e levianos, e o termo "amigos" para se referir aos bons e ponderados.

- Pois bem, Gorgo, - concluiu Periandro impóe-se que exponhas o caso na presença de todos, ou dizendo melhor, que proclames em tom mais elevado, à maneira destes novos ditirambos, a notícia que acabaste de trazer. $^{98}$

18. Gorgo contou então que havia celebrado sacrifícios durante três dias, sendo que o último comportava uma vigília nocturna, danças corais e jogos junto à praia. A lua brilhava sobre o mar e, embora não soprasse vento e houvesse pelo contrário grande calmaria e quietude, começou a avistar-se ao longe uma crispação que avançava em direcção ao promontório, acompanhada de escuma ligeira e de um bramido intenso devido à ondulação que produzia em volta, a ponto de todos acorrerem, maravilhados, para o lugar onde se esperava que tocasse em terra. E antes que, devido à grande velocidade, pudessem imaginar o que se avizinhava, apareceram diante dos nossos olhos golfinhos: uns em grupo e dispostos em círculo, outros que se dirigiam para a zona mais chã da praia, outros ainda que ficavam atrás, como se formassem uma escolta. Ao centro, emergia à superfície do mar a massa indistinta e indefinida de um corpo que era transportado, até que os golfinhos se juntaram todos e acostaram em conjunto, depositando em terra um homem que respirava ainda e se

${ }^{98} \mathrm{O}$ ditirambo é um canto coral dedicado a Diónisos, cuja criação os antigos atribuíam a Aríon (cf. Heródoto, 1.23). 
mexia. Em seguida, os golfinhos retomaram a direcção do promontório, dando saltos ainda maiores, como se estivessem a brincar e a fazer acrobacias devido a uma alegria inexplicável.

— Muitos de nós - continuou Gorgo - ficaram tomados de pânico e fugiram do mar a correr, mas uns quantos (entre os quais me contava eu) encheram-se de coragem e aproximaram-se o suficiente para reconhecerem o citaredo Aríon, que conseguiu pronunciar o próprio nome, além de que era facilmente reconhecível pelas в roupas. Com efeito, envergava ainda o traje de cerimónia que costumava usar quando cantava em concursos, fazendo-se acompanhar da cítara. Transportámo-lo em seguida até uma tenda, pois não parecia ter sofrido qualquer ferimento, embora estivesse visivelmente moído e esgotado pela velocidade e rapidez do transporte. Depois, escutámos da boca dele uma história incrível para toda a gente, menos para nós que tínhamos assistido à sua conclusão! Narrou então Aríon que havia tomado, algum tempo atrás, a decisão de sair de Itália e que a recepção de uma carta de Periandro veio acentuar ainda mais esse propósito. Assim, quando atracou no porto um navio mercantil proveniente de Corinto, subiu de imediato a bordo e fez-se ao largo. Decorridos três dias de vento favorável, Aríon teve o pressentimento de que os marinheiros projectavam tirar-lhe a vida e ficou depois a saber pelo piloto - o qual lhe confiou essa informação em segredo - que eles estavam decididos a pôr c o plano em acção nessa mesma noite. Ora encontrando -se ele sozinho e sem possibilidade de obter auxílio, 
decidiu dar seguimento a uma ideia de inspiração divina: adornar-se e, estando embora vivo, endossar como vestimenta fúnebre o seu traje de cerimónia e entoar um último canto em honra da vida, agora que estava para terminá-la, mostrando com este gesto uma nobreza não menor que a dos cisnes. ${ }^{99}$ Ora uma vez concluídos estes preparativos, anunciou que desejava entoar um dos seus hinos a Apolo, a fim de acautelar a própria segurança, a do barco e a de todos os tripulantes. Tomou então um lugar na ponta do barco, junto à popa, principiou por modular como prelúdio uma invocação aos deuses marinhos e depois pôs-se a entoar o hino. Quando não havia ainda chegado a meio da ode, o sol começou a mergulhar nas águas e a costa do Peloponeso a aparecer no horizonte. Então, os marinheiros decidiram não esperar pela noite e avançaram com intenção de matá-lo. Ao ver os punhais desembainhados e o piloto que já cobria os olhos, ele tomou balanço e lançou-se borda fora, para o mais longe possível do barco. Antes que o corpo ficasse completamente submerso pelas águas, alguns golfinhos puseram-se a nadar debaixo dele e trouxeram-no à superfície. De início, ficou completamente confuso, ansioso e atarantado. Porém, ao constatar a facilidade com que o transportavam, ao ver os golfinhos agrupados em grande número, amigavelmente, à sua volta, assumindo à vez aquela tarefa, como se fosse obrigatório nela tomar parte e a todos dissesse respeito, e ao ter a sensação da

${ }^{99}$ A identificação entre o poeta e o cisne é um motivo frequente na poesia grega. Platão, Fédon (84e) diz pela boca de Sócrates que, na hora da morte, os cisnes cantam com sentida alegria, por terem consciência de estarem para se unir ao seu senhor, Apolo. 
velocidade a partir do facto de o barco ter ficado bem para trás, sentiu nascer dentro de si — contou ele náo tanto o receio perante a morte nem propriamente um desejo de viver, mas antes o orgulho de poder salvar -se (aparecendo como um homem caro aos deuses) e desenvolver uma crença inabalável no respeitante à divindade. Por outro lado, ao contemplar o céu repleto de estrelas e a lua a elevar-se, cintilante e límpida, ao mesmo tempo que o mar se apresentava a toda a volta sem ondas, como que oferecendo um trilho aberto para lhes servir de caminho, pensou para consigo mesmo que a Justiça não possui um olho apenas, mas que com estes múltiplos olhos a divindade observa em todas as direcçóes o que vai sendo praticado, tanto em terra como no

F mar. ${ }^{100}$ Disse ainda que, através destas cogitaçóes, ia encontrando lenitivo para suportar a fadiga que já se abatia sobre o seu corpo. E por fim, quando lhes apareceu pela frente o promontório, íngreme e alcantilado, os golfinhos evitaram-no facilmente, descrevendo uma curva sobre a superfície das águas, e foram nadando ao longo da praia, como se estivessem a conduzir em segurança um barco até ao porto. Nessa altura, Aríon compreendeu perfeitamente que o seu resgate fora conduzido por um deus.

I62A - Depois de Aríon haver relatado estes pormenores, — continuou Gorgo — perguntámos-lhe onde

${ }^{100}$ Há aqui, possivelmente, uma referência a uma tragédia hoje perdida. Com efeito, noutro ponto dos Moralia (Contra Colotes, 1124f), Plutarco faz a seguinte afirmação: «existe um olho da Justiça, que tudo observa» (= Trag. Adesp. 421). Pode também

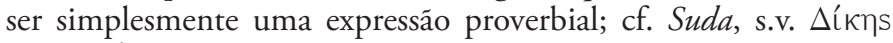

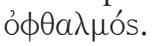


iria, em sua opiniáo, o barco atracar. Ele respondeu que seria certamente em Corinto, mas que, em todo o caso, ainda tardaria muito a chegar. Com efeito, depois de, ao fim da tarde, se haver lançado borda fora, ele achava que o teriam transportado durante não menos de cinquenta estádios; ${ }^{101}$ e entretanto, a calmaria teria retido o navio.

Ainda assim, Gorgo esclareceu que logo se informou acerca do nome do armador e do piloto, bem como do emblema do barco, tendo também enviado navios e soldados para montarem guarda aos locais de desembarque. Quanto a Aríon, tinha-o trazido consigo às escondidas, a fim de evitar que os culpados, ao tomarem conhecimento prévio do seu salvamento, se pusessem em fuga. Na verdade, tudo parecia ter acontecido segundo os desígnios da divindade: com efeito, logo à chegada a Corinto, ficara a saber que o barco havia sido entretanto arrestado pelos soldados, que tinham capturado igualmente os comerciantes e os marinheiros. ${ }^{102}$

19. Periandro deu então instruçôes a Gorgo para que partisse de imediato e fosse meter aquelas pessoas na prisão, de maneira a ninguém ter acesso a elas e não as poder informar de que Aríon escapara são e salvo.

${ }^{101}$ Embora a medida do estádio grego fosse ligeiramente variável, cinquenta estádios equivaleriam a cerca de $90 \mathrm{~km}$.

${ }^{102}$ Era usual que tanto passageiros ocasionais (como Aríon), como os comerciantes embarcassem em navios de transporte de mercadorias. No caso destes últimos, tratava-se inclusive de uma medida de precaução, para garantir que as mercadorias chegavam ao destino nas melhores condiçóes. Por conseguinte, embora a presença de comerciantes a bordo fosse normal, não houve ainda assim, no relato feito, qualquer indicação de que pudessem estar envolvidos no atentado contra Aríon. 
- E logo vós, - comentou Esopo - que andais a fazer caçoada só por os meus gaios e corvos falarem uns com os outros, quando há golfinhos a cometer proezas como estas!

- Vamos antes mudar de assunto, Esopo. - respondi eu, virando-me para ele - Sobre um relato deste género, que entre nós foi dado como seguro e registado por escrito, já passaram mais de mil anos, precisamente desde os tempos de Ino e Átamas. ${ }^{103}$

Sólon entrou também na conversa e disse:

- Ainda assim, Díocles, é de reconhecer que estes fenómenos se situam num domínio mais perto dos deuses e muito acima da nossa dimensão. No entanto, o que se passou com Hesíodo é bem humano e próximo de nós. ${ }^{104}$ De resto, já deves ter ouvido contar igualmente esta história.

- Na verdade, não ouvi. — retorqui.

- Pois ela bem merece ser conhecida. Ora havia certo homem de Mileto, segundo parece, que era, juntamente com Hesíodo, hóspede e comensal em Lócride. Acontece que ele mantinha em segredo uma relação com a filha do anfitriáo e, depois de ter sido apanhado

${ }^{103}$ Ino, filha de Cadmo, foi casada com Átamas. Hera viria a provocar a loucura em ambos, pelo facto de terem recolhido em casa o pequeno Diónisos, fruto dos amores de Zeus e de Sémele (irmã de Ino). Inconsolável por ter morto o filho mais novo (Melicertes), Ino lançou-se ao mar, mas as divindades marinhas tiveram pena dela e transformaram-na numa Nereide: Leucótea (a 'deusa branca'), que protegia os marinheiros.

${ }^{104} \mathrm{O}$ relato da morte de Hesíodo aparece já em Tucídides (3.96), se bem que a versão mais completa pertença a Plutarco, Sobre a inteligência dos animais, 969e, 984d. 
em flagrante, recaiu sobre Hesíodo a suspeita de que ele estaria a par da situação desde o início e teria inclusive ajudado a dar cobertura à iniquidade. E embora Hesíodo não tivesse culpa de nada, isso deu azo a que, naquela circunstância, fosse injustamente vítima de cólera e de calúnia. Com efeito, os irmãos da rapariga acabaram por matá-lo, armando-lhe uma emboscada nas imediaçóes do templo de Zeus Nemeu, em Lócride, onde pereceria também o seu companheiro de viagem, de nome Troilo. Quanto aos corpos, lançaram-nos ao mar. O de Troilo foi arrastado até à embocadura do rio Dafno, até encalhar num recife rodeado de água e que aflorava ligeiramente acima do nível do mar; ainda agora dão a esse escolho o nome de "Recife de Troilo". Já o cadáver de Hesíodo, assim que se afastou da costa, logo um grupo de golfinhos o levou para Ríon, em Molicria. Ora dava -se o caso de os habitantes de Lócride estarem a oferecer sacrifícios e a celebrar as festas solenes das Rias, que ainda hoje em dia se continuam a organizar com todo o esplendor, naquele mesmo lugar. ${ }^{105}$ Assim que avistaram o corpo a ser assim transportado, ficaram naturalmente surpreendidos e correram em direcção à costa. Reconheceram o cadáver ainda recente e puseram à frente de qualquer outra diligência a preocupação de investigar o assassínio, em homenagem à fama de que gozava Hesíodo. E depressa atingiram o objectivo: assim que descobriram os responsáveis pelo homicídio, logo os lançaram ao mar, ainda vivos, arrasando em seguida as suas

${ }^{105}$ É curioso notar que, tal como se verificava na história de Aríon, também agora está a decorrer uma festividade à beira mar, no momento em que os golfinhos aparecem. 
casas. Quanto a Hesíodo, deram-lhe sepultura junto do templo de Zeus Nemeu. A maioria dos estrangeiros não sabe onde fica o túmulo, pois a sua localização foi mantida cuidadosamente em segredo, porque, segundo se conta, os habitantes de Orcómeno andaram à procura da tumba a fim de, em obediência a um oráculo, recuperarem os restos mortais e lhes darem sepultura na sua terra. ${ }^{106}$ Ora se os golfinhos demonstram um interesse

F tão familiar e humano em relação aos mortos, afigura -se provável que procurem ajudar os vivos ainda com maior empenho, em especial quando são convocados pela sonoridade das flautas e de certos cantos. E isto devido ao facto, como todos sabemos, de estes animais se sentirem atraídos pela música, que seguem, nadando ao lado dos marinheiros que remam ao ritmo do canto ou da flauta e divertindo-se com acrobacias, quando o tempo está sereno. Agrada-lhes também nadar com as I63A crianças e fazer com elas concursos de mergulho. Por este motivo, existe mesmo uma lei não escrita que lhes assegura imunidade: com efeito, ninguém os pode caçar ou fazer mal, excepto quando entram nas redes de pesca e prejudicam a faina; nessa altura, são punidos com vergastadas, à semelhança das crianças que fazem asneiras. Recordo-me também de ter ouvido uns homens de Lesbos falar de uma rapariga que os golfinhos resgataram do mar. Mas Pítaco é que conhece bem os pormenores

${ }^{106}$ Esta solução havia sido indicada pelo oráculo de Apolo em Delfos, como remédio para a peste que assolava pessoas e animais, em Orcómeno. Segundo Pausânias (9.38.3-4), teria sido a própria Pitonisa a dar informaçóes sobre o paradeiro dos restos mortais de Hesíodo. 
desse relato, de forma que me parece mais correcto que seja ele a apresentá-lo.

20. Pítaco respondeu, então, que se tratava de uma história bastante famosa e que era muitas vezes recordada. ${ }^{107}$ Com efeito, os colonos fundadores de Lesbos haviam recebido o seguinte oráculo: quando, no decurso da sua viagem de barco, encontrassem um rochedo chamado Mesogéon, deveriam atirar ao mar, nesse mesmo local, um touro em honra de Poséidon e uma virgem ainda viva, em louvor de Anfitrite e das Nereides. Ora havia sete reis a comandar a expedição, sendo Equelau o oitavo, a quem o oráculo de Apolo designara como chefe da colónia, se bem que fosse ainda jovem e solteiro. Entáo os outros sete (ou os que tinham ainda filhas por casar) tiraram à sorte a virgem a sacrificar e a sorte designou a filha de Esminteu. Quando chegaram ao local, vestiram-na a rigor, adornaram-na com jóias de ouro e, depois de formularem os votos, preparavam-se para lançá-la borda fora. Ora dava-se o caso de se haver dela enamorado um dos participantes na expedição, um jovem de origem nada vil, ao que parece, e cujo nome seria Énalo, segundo reza a tradição. Movido pelo desesperado anseio de socorrer a jovem naquela desgraça, quando chegou o momento fatal avançou em frente, envolveu-a com os braços e lançou-se juntamente

${ }^{107}$ No tratado Sobre a inteligência dos animais (984e), Plutarco volta a evocar rapidamente esta lenda, apontando como fonte Mírsilo de Lesbos. Ateneu (11.466c) apresenta o mesmo relato, com algumas variantes, hasteando-se na autoridade de Anticlides de Atenas. 
com ela ao mar. Ora correu desde logo um boato, sem fundamento seguro, ainda que tenha convencido muitos dos que participavam na expedição, relativo à forma como eles teriam sido salvos e resgatados. Diz-se também que, algum tempo depois, Énalo apareceu em Lesbos e contou que haviam sido levados por golfinhos através do mar e deixados em terra firme, completamente ilesos. Relatou ainda outros factos mais extraordinários, que espantaram e deliciaram a multidão, facultando em todo o caso, com a sua conduta, a confirmação de quanto havia dito. Com efeito, na altura em que uma vaga gigantesca envolveu a ilha, deixando a populaçáo tomada pelo

D terror, ele avançou sozinho em direcção ao mar***108 sendo seguido por alguns polvos, até ao santuário de Poséidon. O maior entre eles trazia uma pedra, que Énalo consagrou e é assim ${ }^{109}$ que continua a ser chamada. Regra geral, — concluiu Pítaco — se soubéssemos distinguir bem entre o impossível e o insólito, entre o absurdo e o inesperado, não nos mostraríamos, Quílon, nem crédulos nem incrédulos ao calha, mas antes seríamos capazes de observar o «Nada em excesso!», como tu recomendas. ${ }^{110}$

${ }^{108} \mathrm{O}$ editor assinala a existência provável de uma lacuna neste ponto.

${ }^{109} \mathrm{O}$ editor assinala aqui uma crux. Ainda assim, o mais provável é que a história corresponda a uma explicação etiológica para o nome Énalo, aplicado possivelmente à pedra em questão, à imagem do que atrás foi dito já sobre o "Recife de Troilo".

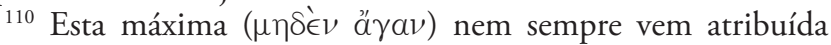
a Quílon. Platão (Protágoras, 343b) diz que foram os sábios em conjunto que a dedicaram a Apolo, em Delfos. 
21. A seguir a ele, interveio Anacársis, para dizer que, depois de Tales ${ }^{111}$ ter avançado a excelente ideia de que a alma existe em todas as partes dominantes e mais importantes do mundo, não será de admirar que as coisas mais belas se cumpram por desígnio do deus:

- Com efeito, o corpo é um instrumento da $\mathrm{E}$ alma, como a alma o é de deus. E da mesma forma que um corpo tem muitos movimentos motivados por si mesmo, ainda que a grande maioria e os mais belos provenham da alma, também a alma, por seu lado, ora realiza algumas acçóes movida por si própria ora se coloca à disposição do deus para que ele a conduza e dirija da maneira que lhe aprouver, pois ela é o mais versátil de todos os instrumentos. Com efeito, - continuou ele - seria altamente estranho que, sendo o fogo um instrumento do deus, tal como o vento, a água, as nuvens e a chuva, e que através deles o deus salve e alimente muitas coisa, da mesma forma que destrói e aniquila outras tantas, e que, por outro lado, o mesmo deus simplesmente não recorresse nunca aos seres vivos para levar a cabo um qualquer dos seus desígnios. Ora afigura-se provável, pelo contrário, que as criaturas dependentes da potência do deus lhe prestem serviços e respondam aos seus movimentos melhor ainda do que os arcos respondem aos Citas ou as liras e flautas aos Helenos. ${ }^{12}$

${ }^{111}$ Esta ideia aparece, de facto, frequentemente atribuída a Tales (e.g. Aristóteles, Sobre a alma, 411a7).

${ }^{112}$ A contraposição entre Citas e Gregos é feita através de utensílios que colhem a preferência de uns e outros: arcos e flechas, no primeiro caso; liras e flautas, no segundo. Em todo o caso, as ideias aqui expressas têm mais que ver com as convicçóes de Plutarco do que com as do sábio cita, a avaliar pelo que se conhece do seu 
A seguir a estas intervençóes, o poeta Quérsias recordou ainda, a propósito de pessoas que, contra toda a expectativa, conseguiram salvar-se, o caso de Cípselo, pai de Periandro. Com efeito, os emissários encarregados de lhe tirar a vida, quando era ainda um recém-nascido, desistiram do propósito só porque ele lhes sorriu; e depois de mudarem novamente de opiniáo e de o procuraI64A rem, já não conseguiram encontrá-lo, pois a máe tinha-o ocultado num baú. ${ }^{113}$ Por este motivo, Cípselo mandou construir um tesouro em Delfos, na firme convicção de que o deus havia, então, estancado o seu choro, a fim de ele poder escapar aos que o procuravam.

Nesse momento, Pítaco dirigiu a palavra a Periandro e observou:

- Quérsias agiu bem, Periandro, ao recordar a questão do tesouro. Na verdade, já por várias vezes eu tinha intenção de inquirir junto de ti a razão de ser daquelas rás e o motivo por que foram esculpidas em número tão elevado, na base da palmeira, e ainda qual a relação que estabelecem com o deus ou com a pessoa responsável pela oferta do edifício. ${ }^{114}$

pensamento.

${ }^{113}$ Em grego, o termo usado para referir uma 'caixa' ou 'baú é

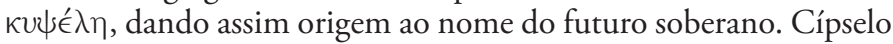
foi o responsável pela introdução da tirania em Corinto, havendo reinado entre 657 e 627 a.C. Para mais pormenores sobre a história do atentado contra esta marcante personalidade, vide Heródoto, 5.92.3.

${ }^{114}$ No tratado Sobre os oráculos da Pitia (400d), Plutarco volta a evocar esta questáo. A palmeira de bronze é símbolo de poder duradoiro, ao passo que as rás remetem para a ideia de renovação constante e, por conseguinte, para a própria abundância e perenidade. 
Dado que Periandro o convidava a endereçar a pergunta antes a Quérsias, pois ele deveria saber a resposta, na medida em que se encontrava junto de Cípselo na altura da dedicação do tesouro, Quérsias retorquiu, com um sorriso:

- Não darei a explicação, antes de saber da parte destas pessoas o que, em seu entender, significam as máximas "nada em excesso» e "conhece-te a ti mesmo», bem como aquela que impediu muitas pessoas de se casarem, outras de confiarem e outras até de fazerem uso da palavra: "com a garantia dada, logo vem a desgraça». ${ }^{115}$

- E para que necessitas das nossas explicaçóes? — ripostou Pítaco - De facto, há muito tempo já, segundo consta, Esopo compôs uma fábula para cada uma destas sentenças, e tu não lhe poupas elogios!

- Assim é, - respondeu Esopo - quando Quérsias pretende brincar comigo. Mas se está a falar a sério, procura demonstrar que o seu inventor é Homero. Com efeito, afirma que Heitor «se conhece a si mesmo", pois, ao avançar sobre os inimigos,

evitava o combate com Ájax, filho de Télamon; ${ }^{116}$

${ }^{115}$ Esta última sentença aconselhava a evitar fazer promessas de casamento, dar garantias em favor dos amigos ou até mesmo emitir qualquer juízo, pois todas estas acçóes comportavam uma forma de caução, da qual poderia resultar a ruína. A atribuição destas máximas conhece muitas variantes, se bem que haja uma tendência global para atribuí-las ao grupo dos Sete Sábios, que teriam feito inscrever algumas delas no santuário de Apolo, reforçando assim a ligação entre a ética sapiencial e a moralidade oracular délfica. Plutarco deve concordar com esta perspectiva, na medida em que póe Quérsias a pedir esclarecimentos aos Sete Sábios sobre o significado das sentenças.

${ }^{116}$ Iliada, 11.542. 
e que Ulisses, apreciador do "nada em excesso», dava este conselho a Diomedes:

Tidida, não me louves nem repreendas em demasia. ${ }^{117}$

Quanto à "garantia», a maioria das pessoas pensa que ele a reprova, como coisa desprezível e inútil, quando sustenta que

de nada vale a garantia se é dada por quem nada vale. ${ }^{118}$

Todavia, este nosso Quérsias acha que a Desgraça foi por Zeus expulsa do Olimpo, por se encontrar presente quando ele se comprometeu com uma garantia, que o induziria em erro, por alturas do nascimento de Héracles. ${ }^{119}$

Sólon tomou então a palavra e disse:

- Ora convém dar crédito igualmente à grande sabedoria de Homero, quando ele afirma

A noite já vem adiantada: e é bom também à noite

[obedecer. ${ }^{120}$

${ }^{117}$ Iliada, 10.249.

${ }_{118}$ Odisseia, 8.351.

${ }^{119}$ Cf. Ilíada, 19.91-131. No dia me que Alcmena estava para dar à luz Héracles, Zeus assumiu, por juramento, que a criança que estava para nascer seria rei dos Argivos. Hera, no entanto, irada com a perspectiva de Zeus premiar o filho da amante, atrasou o parto de Alcmena, antecipando o nascimento de Euristeu, que assim veio a ficar à frente do governo de Argos.

${ }^{120}$ Ilíada, 7.282 e 293. 
Façamos pois libaçôes às Musas, a Poséidon e a Anfitrite e, se vos parecer bem, vamos dar por terminado o banquete.

- E assim, Nicarco, se deu por terminado o encontro daquele dia. 


\section{ÍNDICE DE NoMES}

Afrodite: 146d; 156c; cf. Cípria

Agamémnon: $156 \mathrm{f}$

Ájax filho de Télamon: 164c

Alexidemo de Mileto: 148e;

149b; $149 \mathrm{e}$

Aliates: $153 \mathrm{e}$

Âmasis: 151b; 151c; 151d;

152e; 153a; $153 \mathrm{e}$

Anacársis: 148c; 148d; 150d;

152a; 154e; 155a; 155f; 156a;

$158 \mathrm{a} ; 163 \mathrm{~d}$

Anfidamante: $153 \mathrm{e}$

Anfitrite: 163b; 164d

Árdalo de Trezena: 149f; 150a;

150d; 155e; 157d; 157e

Árdalo-o-Velho de Trezena: 150a

Aríon: 161a; 161b; 162a; 162b

Arquíloco: 152e

Asclépio: $159 \mathrm{f}$

Átamas: $162 \mathrm{c}$

Atenas: 152d; 158b

Atenienses: 151e; 152c; 154d

Báticles: $155 \mathrm{e}$

Bias: 146e; 146f; 150b; 151a;

151b; 151c; 151d; 152a; 154d;

155c; 155e; 160e

Busíris (habitantes de): $150 \mathrm{f}$

Cálcis: $153 \mathrm{e}$

Cípria: 155f; cf. Afrodite

Cípselo: 163f; 164a; 164b

Citas: 148e; 150d; 150e; $163 \mathrm{f}$

Cleobulina: 148c; 150e; cf.

Eumétis

Cleobulo: 151c; 152b; 154e; 155d; 157a; 157c

Cleodoro: 152d; 153d; 153e;

154a; 154c; 156f; 157c; 158a;

158c; 158f; 159e

Core: $159 \mathrm{e}$

Corinto: 162a

Creso: 150a; 155b

Dafno: 162d

Danaides: 160b

Delfos: 150a; 164a

Délios: 158a

Deméter: 158d; 159e

Desgraça (Ate): 164c

Díocles: 149d; 149e; 150b;

151f; 155c; 162c

Diomedes: 164c; cf. Tidida

Diónisos: 150b; 155f; 156c;

156d; 158e; cf. Libertador

Egípcios: 148a; 149a; 150f;

151b; 151e; 159b

Egipto: 146e; 148d; $151 \mathrm{f}$

Elefantine: $151 \mathrm{~b}$

Énalo: 163b; 163c; 163d

Eólios: $148 \mathrm{f}$

Epiménides: 157d; 157e; 158b

Equelau: $163 \mathrm{~b}$

Éreso: $157 d$

Erétrios: $153 \mathrm{f}$

Esminteu: 163b

Esopo: 150a; 150e; 152b; 152d;

152e; 154b; 154f; 155a; 155c;

155e; 156a; 157b; 158b; 162b;

$164 \mathrm{~b}$

Etíopes: $151 \mathrm{~b}$ 
Eumétis: 148c; 150b; 154a;

154b; 155e; cf. Cleobulina

Gorgo: 160d; 160e; 161a; 162a;

$162 b$

Hades: 159b

Heitor: $164 \mathrm{c}$

Helenos: 146e; 150e; 151b;

153e; $163 \mathrm{f}$

Héracles: $164 \mathrm{c}$

Hesíodo: 154a; 156e; 157e;

157f; 158a; 158b; 162c; 162d;

$162 \mathrm{e}$

Homero: 151e; 156e; 160a;

164b; 164d

Ino: $162 c$

Itália: $161 b$

Justiça: 161e

Lábis de Delfos: $155 \mathrm{f}$

Lacedemónios: 152a

Lelanto: $153 \mathrm{f}$

Lequeu: $146 \mathrm{c}$

Lesbos (habitantes de): 153e;

163a; $163 \mathrm{c}$

Lesques: $154 \mathrm{a}$

Lídia: 150a

Libertador (Diónisos): 150c

Licurgo: 152a; 155d

Lócride: 162c; 162d

Lua: $157 \mathrm{a} ; 158 \mathrm{~d}$

Melissa: 146d; 150b; 150d;

$155 \mathrm{e}$

Mesogéon: 163a

Messénios: 159e
Mírsilo: $147 \mathrm{~b}$

Mitilene: $157 \mathrm{e}$

Mnesífilo: 154c; 154d; 155e;

156a; 156b; 156e

Molicria: 162d

Molpágoras da Iónia: 147b

Musa: 154a; Musas: 155f; 156b;

156d; 164d; Musas Ardálidas:

$150 \mathrm{a}$

Náucratis: 150b; 150f; habitante de: 151c; cf. Nilóxeno

Nemeu: 162d; 162e

Nereides: 163b

Nicarco: 146b; 153a; 160c;

$164 d$

Nilóxeno de Náucratis: 146e; 147a; 148d; 149d; 150e; 150f; 151a; 151b; 151c; 151d; 151e; 152e; 152f; 153a; 153c; 153e; cf. Náucratis

Orcómeno (habitantes de): 162e Orfeu: 159c

Peloponeso: 161d

Periandro: 146c; 147c; 148b; 148e; 149c; 149e; 150a; 150b; 150c; 150f; 151e; 152b; 152e; 153e; 154c; 154e; 155e; 156d; 156e; 157e; 160d; 161b; 162b; 163f; 164a; 164b

Pítaco: 147b; 147c; 152b; 153e; 154e; 155d; 155e; 155f; 156a; 157d; 157e; 163a; 164a; 164b Poséidon: 158e; 160d; 163b; 163d; 164d Priene: $146 \mathrm{e}$ 
Quérsias: 156e; 156f; 157a;

157b; 157c; 163f; 164a; 164b;

$164 \mathrm{c}$

Quílon: 148a; 150b; 151d;

151e; 151f; 152b; 152d; 154e;

155d; 155e; 156a; 156e; 163d

Rias (festas): 162d

Ríon: $162 \mathrm{~d}$

Rochas Errantes: 156f

Sete Sábios: $146 c$

Sibaritas: $147 \mathrm{e}$

Sícion (habitantes de): 154c

Sol: 158d; Carro do: 155a

Sólon: 146e; 147c; 150a; 151e;

151f; 152a; 152c; 152d; 154c;

154d; 155b; 155c; 155e; 156a;

156b; 156c; 157d; 157e; 158a;

158b; 159a; 160d; 162c; 164d

Tales: 146c; 146d; 146e; 147b;

$148 \mathrm{~b} ; 148 \mathrm{c} ; 148 \mathrm{~d} ; 148 \mathrm{e} ; 149 \mathrm{~b}$;

149c; 149d; 149e; 149f; 150b;

152a; 152d; 153a; 153b; 153c;

153d; 154e; 155d; 157d; 158c;

160e; $163 \mathrm{~d}$

Tártaro: $159 \mathrm{~b}$

Ténaro: 160d

Tidida: 164c; cf. Diomedes

Tífon: $150 \mathrm{f}$

Trasibulo: 147c; 148e; 148f;

149b; 149c

Troilo: $162 \mathrm{~d}$

Ulisses: $164 \mathrm{c}$

Zeus: 152f; 154a; 156e; 156f;

158d; 162d; 162e; 164c 


\section{ANEXO}

Explicação sobre a forma como Tales teria procedido à medição de uma pirâmide no Egipto. Cf. O Banquete dos Sete Sábios, 147A, supra pp. $54-55$ e n. 9.

\section{1 ' MÉTOdo}

Sol

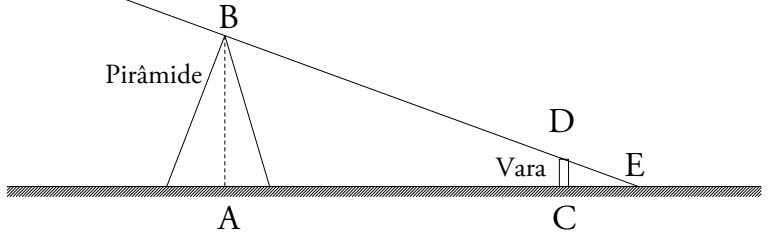

Este método baseia-se no facto de os triângulos rectângulos [ABE] e [CDE] serem semelhantes, pelo que: $\frac{\overline{A B}}{\overline{C D}}=\frac{\overline{A E}}{\overline{C E}}$. Assim, colocando a vara na posição indicada no esquema, e medindo $\overline{A E}=($ Comprimento da sombra da pirâmide, medido desde o centro A da sua base), $\overline{C E}=$ (Comprimento da sombra da vara) e $\overline{C D}=$ (Altura da vara), a altura $\overline{A B}$ da pirâmide pode ser calculada através de $\overline{A B}=\frac{\overline{A E}}{\overline{C E}} \times \overline{C D}$.

Este método pode ser usado em qualquer hora do dia em que a sombra da pirâmide seja visível (o que implica que o ponto $\mathrm{E}$ esteja colocado fora da sua base), mas é mais preciso no princípio ou no final do dia, quando o ângulo $九$ (AEB) é pequeno. $\mathrm{O}$ método é também tanto mais preciso quanto maior for a altura $\overline{C D}$ da vara. 


\section{Método}

Raios solares
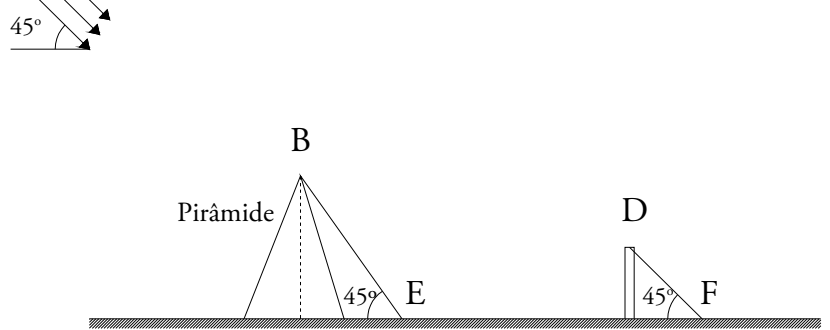

A

C

Este método baseia-se, em primeiro lugar, no facto de os raios solares incidentes sobre a superfície da Terra serem praticamente paralelos, devido à grande distância que medeia entre o Sol e a Terra. Deste modo, em qualquer hora do dia e qualquer que seja a posição da vara, os triângulos rectângulos $[\mathrm{ABE}]$ e $[\mathrm{CDF}]$ são semelhantes, sendo os lados $[\mathrm{BE}]$ e $[\mathrm{DF}]$ paralelos entre si e aos raios solares, pelo que: $\frac{\overline{A B}}{\overline{A E}}=\frac{\overline{C D}}{\overline{C F}}$. Em segundo lugar, o método baseia-se no facto de, à hora do dia em que $九(\mathrm{AEB})=\Varangle(\mathrm{CFD})=$ 450, ser, em particular, $\frac{\overline{A B}}{\overline{A E}}=\frac{\overline{C D}}{\overline{C F}}=1$. A esta hora, portanto, tem-se, por um lado, $\overline{C F}=\overline{C D}$, e, por outro lado, $\overline{A B}=\overline{A E}$. A verificação da primeira condição requer a medida de $\bar{C} \bar{D}=$ (Altura da vara) e $\overline{C F}=($ Comprimento da sombra da vara), esta última, variável com a hora do dia. Para conhecer a altura $\overline{A B}$ da pirâmide basta, entáo, medir $\overline{A E}=$ (Comprimento da sombra da pirâmide) à hora a que a primeira condição ocorre.

Tal como no método anterior, a precisão de medida da altura $\overline{A B}$ da pirâmide melhora com o aumento da altura $\bar{C} \bar{D}$ da vara. 


\section{Volumes publicados na Colecçấo Autores \\ Gregos e LATINOS - SÉrIE TeXtos}

1. Delfim F. Leão e Maria do Céu Fialho: Plutarco. Vidas Paralelas - Teseu e Rómulo. Tradução do grego, introdução e notas (Coimbra, CECH, 2008).

2. Delfim F. Leão: Plutarco. Obras Morais - O banquete dos Sete Sábios. Tradução do grego, introdução e notas (Coimbra, CECH, 2008). 

OBRA PUBLICADA

COM A COORDENAÇÁO

CIENTÍFICA

0

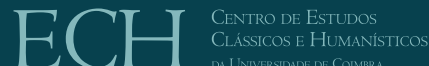

DA UNIVERSTIDAD DE COIMBRA

- $\mathbf{U}$

C •

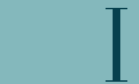

IMPRE VSA DA UNIVERSIDADE DE COINPRA 